Andrews University

Digital Commons @ Andrews University

1985

\title{
A Study of Factors Related to the Numerical Growth of the Seventh-day Adventist Church in Iceland from 1950 to 1980
}

Steinthor Thordarson

Andrews University

Follow this and additional works at: https://digitalcommons.andrews.edu/dmin

Part of the Practical Theology Commons

\section{Recommended Citation}

Thordarson, Steinthor, "A Study of Factors Related to the Numerical Growth of the Seventh-day Adventist Church in Iceland from 1950 to 1980" (1985). Professional Dissertations DMin. 237.

https://dx.doi.org/10.32597/dmin/237

https://digitalcommons.andrews.edu/dmin/237

This Project Report is brought to you for free and open access by the Graduate Research at Digital Commons @ Andrews University. It has been accepted for inclusion in Professional Dissertations DMin by an authorized administrator of Digital Commons @ Andrews University. For more information, please contact repository@andrews.edu. 


\section{ABSTRACT}

\section{A STUDY OF FACTORS RELATED TO THE NUMERICAL GROWTH OF THE SEVENTH-DAY ADVENTIST \\ CHURCH IN ICELAND FROM 1950 TO 1980}

by

Steinthor Thordarson

Chairman: Russell Staples, Ph.D. 
ABSTRACT OF GRADUATE STUDENT RESEARCH

A Project Report

Andrews University

Seventh-day Adventist Theological Seminary

Tit1e: A STUDY OF FACTORS RELATED TO THE NUMERICAL GROWTH OF THE SEVENTH-DAY ADVENTIST CHURCH IN ICELAND FROM 1950 TO 1980

Name of researcher: Steinthor Thordarson

Name and degree of faculty àdviser: Russell Staples, Ph.D. Date completed: May 1985

$$
\text { Problem }
$$

The rate of growth in the Seventh-day Adventist Church in Iceland has not been previously analyzed. This study was undertaken to discover, through historical and numerical analysis, what may have contributed to or hindered growth in the church since 1950 , and to analyze the programs of the church and the patterns of growth. 
Method

A survey of records of the Iceland Conference of Seventh-day Adventists, i.e., the church paper, executive minutes, constituency reports, membership lists, and accounts of outreach emphasis for several decades, presents a clear picture of the methods used in an attempt to achieve church growth.

In addition, a survey was conducted in all the churches in the conference in an attempt to discover the self-understanding of church members concerning their role and function in the church; their involvement in and satisfaction from the church services, and their conception of the community perception of the SDA Church.

\section{Results}

Records show that the work of the SDA Church in Iceland has been conducted in two main stages of evangelism. The rather vigorous evangelistic program conducted during the first part of this century led to the the organization of fourteen churches and companies.

During the second stage the church concentrated upon Christian education. This has served the church well in biological growth, but has not been effective as means of outreach. A new SDA church has not been organized during the last thirty-two years.

The membership tenure in the SDA Church in Iceland has steadily increased for several decades. Presently, 
almost two-thirds of the church members under sixty-six years of age are second and third generation Adventists.

\section{Conclusions}

It is concluded that a change in strategy in

evangelism is necessary in order to improve the rate of growth in the SDA Church in Iceland. Therefore a re-

ordering of priorities is recommended in which more of the resources of the church are channelled towards more direct forms of outreach involving the training and participation of the members of the church. 


\author{
Andrews University \\ Seventh-day Adventist Theological Seminary
}
A STUDY OF FACTORS RELATED TO THE NUMERICAL GROWTH OF THE SEVENTH-DAY ADVENTIST
CHURCH IN ICELAND FROM
1950 TO 1980

\author{
A Project/Dissertation \\ Presented in Partial Fulfillment \\ of the Requirements for the Degree \\ Doctor of Ministry
}

by

Steinthor Thordarson

May 1985 



\title{
A STUDY OF FACTORS RELATED TO THE NUMERICAL \\ GROWTH OF THE SEVENTH-DAY ADVENTIST \\ CHURCH IN ICELAND FROM \\ 1950 TO 1980
}

\author{
A Project/Dissertation \\ presented in partial fulfillment \\ of the requirements for the degree \\ Doctor of Ministry
}

\section{by}

Steinthor Thordarson

APPROVAL BY THE COMMITTEE:
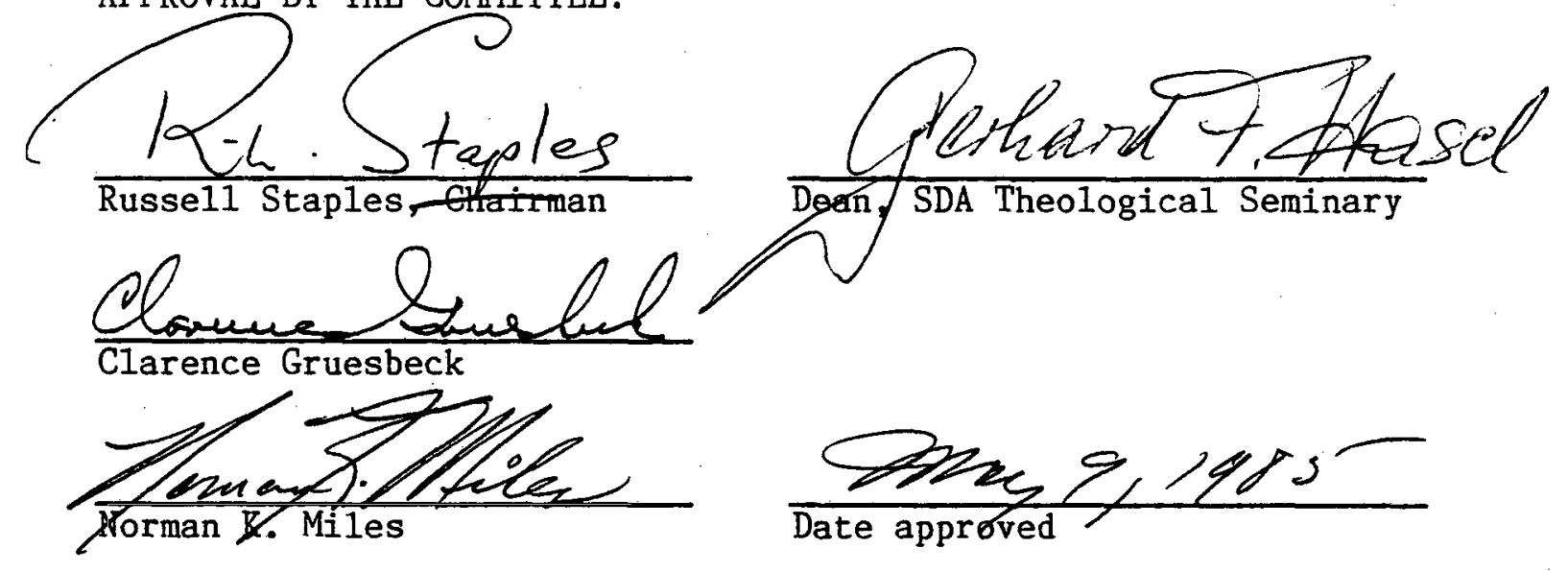
DEDICATION

This project is dedicated to my wife, Lilia, whose sweet disposition and wonderful love has been a constant inspiration throughout our journey together.

And to my children, Throstur, Smart, Thor, and Margret, who are my very special friends. 
TABLE OF CONTENTS

Chapter

INTRODUCTION

Purpose of the Project . . . . . . . . . . . . . 1

Survey Instrument . . . . . . . . . . . . . . . 2

Church Growth Literature . . . . . . . . . . . . 3

Theological Considerations . . . . . . . . . . . . 4

I. BASIC CONCEPTS OF CHURCH GROWTH . . . . . . . . . . 5

Review of Contemporary Literature . . . . . . 5

McGavran and His Propositions ......... 5

Principles of the Church Growth Movement . . . . 9

Reflections Upon Church Growth Theory . . . . . . 11

Introduction ............... 11

Numerical Growth .............. 13

Discipling and Teaching ........... 14

Gospel Proclamation and Social Services . . . 15

The Pastor and His Church Members . . . . . 17

Contributions Acknowledged . . . . . . . . 17

Seventh-day Adventists and Church Growth . . . . . 19

The Caring Church ............. 19

Multi-dimensional Church Growth . . . . . 21

Outreach Through Institutions ........ 22

Changing the Course? ............... 27

Lessons for Adventists in Iceland . . . . . 28

II. THEOLOGICAL CONSIDERATIONS FOR CHURCH GROWTH . . . . . . 35

Justification for Church Growth . ........ 35

Qualitative Growth and Quantitative Growth . . . . 40

God's Work and Man's Work in Church Growth . . . . . 43

The Role of the Holy Spirit in Church Growth . . . . 47

III. ICELAND - HISTORICAL BACRGROUND . . . . . . . . . 52

The Country and the People . . . . . . . 52

Introduction ............... 52

First Settlers ............. 53

Beliefs of the Vikings . . . . . . . . . 54

The Christianization of Icelanders . . . . 56

Confrontation at Althing .......... 58

Formative Period .............. 60

Plagues and Natural Disasters ......... 61 
Iceland Today ............. 63

From Catholicism to Lutheranism . . . . . 63

Witchcraft and Superstition . . . . . . 64

The Supernatural and Spiritism . . . . . . 65

The State Church . . . . . . . . . 66

The Seventh-day Adventist Church in Iceland . . . 68

The First Seventh-day Adventist in Iceland . . 68

David Ostlund ........... 69

Crisis ................. 71

0. J. 01sen Replaces Ostlund . . . . . . . 72

Petur Sigurdsson . . . . . . . . . . 74

Reykjavik Church Building . . . . . . . 76

Vestmannaey jar . . . . . . . . . . . . 76

O1sen's Method of Outreach . . . . . . . . 77

Siglufjordur Church . . . . . . . . . 78

Akureyri Church .... . . . . . . . 78

Skagastrond Church . . . . . . . . . . 79

Faskrudsfjordur Church . . . . . . . . 80

Arnes Church ................ 80

Sudurnes Church . . . . . . . . . 81

Church Schools .......... . . . 82

Secondary School ...... . . . . . . 85

Conference Administration . . . . . . . . 91

Growth Figures . . . . . . . . . . . 95

Evangelistic Campaigns ........... 102

Other Forms of Outreach . . . . . . . . 106

Publishing Work ............. 106

Bible Correspondence School . . . . . . 108

Radio Ministry . . . . . . . . . . 108

Book and Healthfood Store . . . . . . 109

Telephone Answering Service . . . . . . 109

Summer Health Resort . . . . . . . 109

Relief Work . . . . . . . . . 109

Five-day Plan for Smokers . . . . . . 110

Gift Bible Plan . . . . . . . . . . 111

Vacation Bible School ....:. . . . . 111

Summer Camp for Children . . . . . . . 112

The Children's Storyhour . . . . . . . 112

Summary ............... 113

IV. SDA CHURCH GROWTH IN ICELAND . . . . . . . . . . 115

Introduction . . . . . . . . . . 115

Setting for the Survey ............ 116

How the Survey Was Conducted .......... . 117

Procedure for Analysing the Data . . . . . . . 120

Limitations . . . . . . . . . . . . 121

Members Receptivity of Survey . . . . . . . . 122

What the Survey Reveals . . . . . . . . 123

Tenure of Membership . . . . . . . . . 123

Distribution of Respondents by Age . . . . . 125

Sex and Marital Status of Respondents . . . . 126

Adventist Background of Members . . . . . . 127

Educational Background of Members . . . . . . 129 
Influential Factors That Led People to Join Church ........... 130

SDA Parent............. 130

Pastor .............. 131

Public Meetings ........... 133

SDA Books and Pamphlets ........ 134

Hlidardalsskoli .......... 135

SDA Acquaintances . . . . . . . 136

Bible Studies ............ . 137

SDA Church Schools . . . . . . . 138

SDA Relative ............ 138

Bible Correspondence School . . . . . . 139

Members' Evaluation of their Own Spiritual Life . 139

Church Attendance . . . . . . . . 139

Family Worship . . . . . . . . . . 140

Members' Evaluation of the Pastoral Ministry . . 140

Outreach Emphasis ............ 140

Pastoral Visitations . . . . . . . . 141

Pastoral Tenure . . . . . . . . . . 142

Members' Preceptions of the Church . . . . . 142

Soulwinning . . . . . . . . . . 142

Standards of the Christian Life . . . . . 142

Friendliness . . . . . . . . . . 143

Activating New Members . . . . . . . 143

Young People............. . 143

Sabbath Services . . . . . . . . . 144

Public Image of the Church . . . . . . . 144

Witnessing Activities of Church Members . . . 145

Soulwinning ........... 145

Relief and Community Services . . . . . . . 147

A Few Comparisons Between Individual Churches . . 149

The Emphasis on Christian Education . . . . . 154

Hlidardalsskoli's Contribution

to Church Growth . . . . . . . . . 154

Financial Costs . . . . . . . . . 157

In Retrospect . . . . . . . . . 158

Church Members Express Their Interests ..... 161

V. SUMMARY, CONCLUSIONS, AND RECOMMENDATIONS . . . . . 167

Summary and Conclusions ........... . 167

Principles of Church Growth . . . . . . . . 169

Early Evangelism in Iceland .......... 169

Church Growth through Christian Education . . . . 170

Administrative Direction . . . . . . . 170

Church Schools . . . . . . . . . 171

The Secondary School .......... 172

Evangelism in General ........ 173

Present State of the SDA Church in Iceland . . 174

Prospects for Future Church Growth in Iceland - 176

Recommendations .............. 177

Introduction . . . . . . . . . . 177

Programs and Strategies ......... 178

Adventist Presence . . . . . . . 178 
Direct Outreach . . . . . . . . . 178

Statement of Mission . . . . . . . . . 179

Implementation of a Mission Statement . . . . 179

Suggestive Outreach Program . . . . . . . 179

Spiritual Gifts . . . . . . . . . . 182

Equipping . . . . . . . . . . . . 182

Training of Lay-people . . . . . . . . 183

Christian Cel1 Groups . . . . . . . . 183

Felt Needs ................ 184

Visiting .. . . . . . . . . . 185

Regular Church Members .. . . . . 185

Inactive and Former Adventists . . . . 185

Former Students of H1idardalsskoli . . . 185

Other non-Adventists . . . . . . . 186

Advantages of a Homogenous Setting . . . . 186

Changing Priorities ... . . . . . . 187

Goal-setting ............. 188

Evaluations ............... 190

Self-assessment ......... . 190

Church Survey . . . . . . . . . . 190

Survey of Inactive Church Members . . . . 190

Public Survey . . . . . . . . . . 191

Projections ............... 191

APPENDIX A - SURVEYS . . . . . . . . . . . . 201

APPENDIX B - LETTERS AND RESOLUTION . • . . . . . . • . 228

APPENDIX C - TABLES . . . . . . . . . . . . 230

APPENDIX D -- STATEMENT OF MISSION . . . . . . . . . 236

APPENDIX E -- SPIRITUAL GIFTS INVENTORY . . . . . . . . . 240

APPENDIX F - SOME CHARACTERISTICS OF UNHEALTHY

AND HEALTHY ORGANIZATIONS : . . . . . 242

APPENDIX G - A ROADMAP OF ICELAND . . . . . . . . . 245

BIBLIOGRAPHY . . . . . . . . . . . . . . 247

VITA . . . . . . . . . . . . . . . . . 254 


\section{LIST OF FIGURES}

1. Number of Churches Organized During Each of Three time Periods . . . . . . . . . 95

2. Rise and Fall of Icelandic SDA Membership . . . 98

3. Tenure of Membership . . . . . . . . . . 121

4. Distribution of Respondents by Age . . . . . 123

5. Male-Female Distribution of Respondents . . . . 124

6. Adventist Background of Members . . . . . . 125

7. Projected Church Growth .... . . . . . 186 


\section{LIST OF TABLES}

1. Former and Present SDA Churches in Iceland... 92

2. Iceland Conference Membership 1950-1983 . . . . 97

3. Membership Numbers of Denominations in Iceland............... 100

4. Comparisons of Church Growth in Denominations

in Iceland . . . . . . . . . . 101

5. Factors Influencing Decision to Join Church • 127

6. Compilation of Data from Church Survey . . . 202

7. Statistical Survey of Students Attending

Hlidardalsskoli 1950-1982 in Regard to

Church Affiliation . . . . . . . . 224

8. Number of Members Added to the SDA Church

in Iceland --1950-1982-- Without

Hlidardalsskoli Influence . . . . . . 226

9. Number of Years Students with SDA Background

Attended Hlidardalsskoli . . . . . . 228

10. Number of Years Students with Non-SDA

Background Attended Hlidardalsskoli . . . 228 


\section{PREFACE}

It might be to reader's interest to know the location of the country of Iceland. The small map below locates Iceland to its neighboring countries.

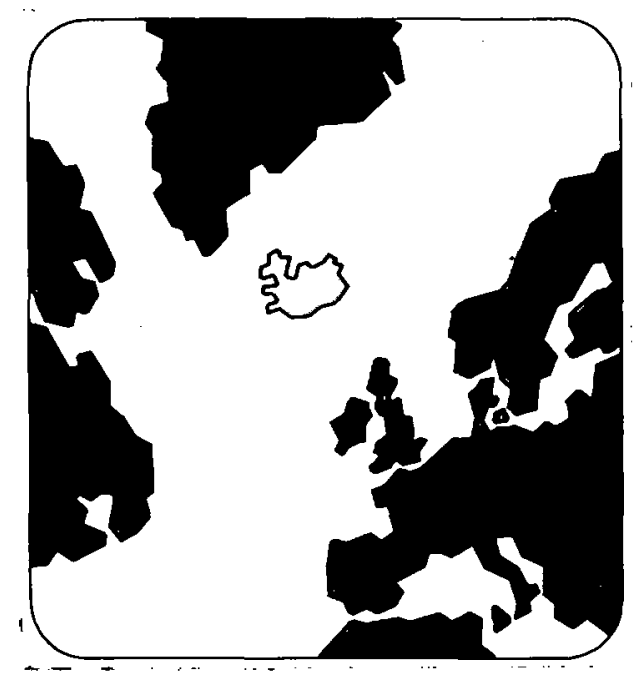

In appendix $G$ appears a roadmap of Iceland showing al1 major towns and cities. A11 the SDA churches mentioned in this study are named after their respective towns, except Sudurnes Church, which is located in the town of Keflavik, and Arnes Church, which is located in the town of Selfoss. Both places are in the southwestern part of Iceland. 


\section{ACKNOWLEDGMENTS}

Mang individuals have contributed to this study. I wish to extend my gratitude to:

The members of the SDA churches in Iceland who, with their participation in the survey, provided me with the insight into the present state of the church;

The ministers in the Iceland Conference of Seventhday Adventists for their cooperation and practical suggestions;

The members of the conference executive committee for giving me access to the churches and the records of the conference;

My son, Throstur, on whom I could always depend for finding the missing pieces of information left behind in Iceland;

My friends, Dr. Arni Holm and Gudmundur Olafsson, for their encouraging support and helpful materials on Hlidardalsskoli;

David Holm and Lilja Olafsson for their crucial computer work;

Joyce Jones, dissertation secretary, for her ever-ready kind counsel on technical matters; 
The members of my doctoral committee for their helpful hints and suggestions which made this a more complete work; and

$$
\text { Dr. Russell Staples, my chairman, to whom especial }
$$
appreciation is extended for his scholarly guidance in the later stages of this project. 


\section{INTRODUCTION}

This study is a careful analysis of the patterns of growth of the Seventh-day Adventist (SDA) Church in Iceland. As far as can be ascertained, such a study has not been done previously. This study was undertaken in an attempt to discover, through historical and numerical analysis, what may have contributed to or hindered growth in the church since 1950. The project grows out of fourteen years of experience, during which I served in various roles as pastor, evangelist, and departmental director in the Iceland Conference of Seventh-day Adventists. The experience has led to the conviction that a more comprehensive planned program of evangelism, both at local church and conference level, would lead to more vigorous growth. This study has served to confirm that conviction.

\section{The Purpose of the Project}

This is an exercise in empirical research grounded in a study of the history of the SDA denomination in Iceland. It is an analysis of factors that have produced growth in the Iceland Conference of Seventh-day Adventists and is based on an interpretation of the history of the church, as well as on the findings of a survey of the 
experience and attitudes of members of the Seventh-day Adventist Church.

The purpose of the study is three-fold:

(1) to isolate and analyze factors which have contributed to or hindered church growth among Adventists in Iceland since 1950;

(2) to discover the prevailing feelings, attitudes, and self-understanding of church members concerning their role and function in the church;

(3) to offer an alternative strategy for church growth in the SDA Church in Iceland.

To accomplish this purpose, I visited Iceland in October 1983 to research church records and conduct a survey of the opinions and attitudes of members in the Adventist Church in Iceland.

\section{The Survey Instrument}

A survey instrument was developed from two existing surveys, the Caring Church Survey and the New Member Survey, developed by the Institute of Church Ministry on the campus of Andrews University, Berrien Springs, Michigan. Changes and adaptations were made in the questions in order to make it applicable to local circumstances and attitudes. The survey instrument gathered 78 items of information.

It was anticipated that the use of the survey instrument would provide specific information about the 
composition of the SDA membership in Iceland, the background of the members, and the factors influencing them to join the SDA church.

Furthermore, information was sought about the members' evaluation of their own spiritual life, as well as their perceptions of the SDA church, the pastoral ministry, and the effectiveness of the present churchgrowth emphasis.

Prior to conducting the survey in the churches, a consultation was held with the conference president, Erling B. Snorrason, concerning the wording and propriety of each question. Furthermore, a meeting of all SDA ministers in the conference was called to give them an opportunity to evaluate and clarify the survey questions. Their suggestions were incorporated in the survey. Only after all were in agreement as to the content and wording of the questions was the surveg utilized in the churches.

\section{Church Growth Literature}

Literature worldwide dealing with church growth has only recently come onto the scene as leaders of Christian churches, drawing upon the findings of surveys conducted during the last three decades, have sought to improve church growth. An endeavor is made in this study to briefly present certain principles conducive to church growth as well as some common criticisms of church-growth 
theory. Some aspects of a Seventh-day Adventist view on church growth are also introduced.

\section{Theological Considerations}

A theological grounding of church-growth thought is provided in the Great Commission, "Make disciples of all nations." In this study, attention is given to four areas of theological consideration: justification for church growth; the sovereignty of God versus the responsibility of man; the relationship between qualitative and quantitative growth; the role of the Holy Spirit in church growth.

Although this study deals entirely with church growth. in the context of the Seventh-day Adventist Church, the principles introduced here are applicable to growth in any Christian church. 


\section{CHAPTER I}

\section{BASIC CONCEPTS OF CHURCH GROWTH}

\section{Review of Contemporary Literature}

McGavran and His Propositions

The Church Growth Movement is a relatively recent phenomenon. The pioneer and key figure of the movement is Donald McGavran. During his thirty-three years (19231955) of service as a Disciple of Christ missionary in India, he observed that while some churches in India were growing, others were not. McGavran concluded that churches whose attention is directed more to groups, families, villages, and towns rather than to individuals are generally successful and usually increase in numbers. Furthermore, he maintained that churches that occupy themselves with the giving of Bible studies, baptizing, and other traditional soul-winning methods on an individual basis are less likely to grow. This is due to their emphasis on the individual and not the group to which the individual belongs.

${ }^{1}$ Gottfried Oosterwal, MSSN 600 Seminar in Church Growth, Classnotes, Andrews University, Berrien Springs, Michigan, 1984. See also Donald McGavran, The Bridges of God (New York: Friendship Press, 1955), and How Churches Grow (Glendale, California: Regal Books, 1976). 
According to McGavran, churches whose organization is flexible and not rigidly structured grow more rapidy. Finally, he contended that "Men and women like to become Christians without crossing cultural barriers."

In 1955, upon returning to the United States, McGavran published his book, The Bridges of God, which outlined a positive program of church growth. He emphasized the need for churches to be flexible according to the New Testament pattern.

McGavran was severely criticized by some readers of his book, mainly those of the mainline churches. He was surprised by the severity of the criticism leveled at his analysis and considered dropping the subject altogether. However, he decided to respond to the criticism and in 1959 he published How Churches Grow, which presents his criticism of the traditional methods of church growth. He accused church leaders of being "foggy" in their churchgrowth thinking. He then proceeded to promote the New Testament strategy of winning people to Christ in groups, families, and clans.

At the outset, McGavran developed his thesis against the backdrop of his missionary experience within the caste structure of India. He coined the term "homogeneous unit principle," through which he promoted

${ }^{1}$ Donald McGavran, Understanding Church Growth (Grand Rapids, Michigan: William B. Eerdmans Publishing Company, 1980), p. 43. 
the theory that people "like to become Christians without crossing racial, 1inguistic or class barriers."

He urged church leaders to come to the realization that "mankind is a mosaic and each piece has a separate life of its own which seems strange and often unlovely to men and women of other pieces." ${ }^{2}$ It was his contention that such mosaic pieces exist in every community. Not realizing this, many evangelists throw their gospel seed on stony ground. They should endeavor to look for the receptive cells in each society, then proclaim the gospel where the receptivity is.

In his subsequent books, McGavran focused on the church's mission among Western cultures, particularly the individualistic American society. He called for individuals who are willing to act as 'explorers' to 'discover a new world' in "the missionary passion of the churches." ${ }^{4}$ Speaking of his favorite theme, evangelism, McGavran stated:

God therefore commands those of His household to go and 'make disciples of all nations.' Fulfilling this command is the supreme purpose which should guide the entire mission, establishing ifs priorities, and coordinate a11 its activities.

$$
\begin{aligned}
& { }^{1} \text { Ibid. }(1970 \text { ed.), p. } 191 . \\
& { }^{2} \text { Ibid. }(1980 \text { ed.), p. } 223 .
\end{aligned}
$$

3 Harvey M. Conn, "Looking for a Method: Background and Suggestions," in Exploring Church Growth, ed. Wilbert R. Shenk (Grand Rapids, Michigan: Eerdmans, 1983), p. 81 .

${ }^{4}$ McGavran, The Bridges of God, p. 154.

${ }^{5}$ McGavran, Understanding Church Growth, p. 43. 
Together with A. R. Tippett, McGavran in 1961

established the Institute of Church Growth at Northwest Christian College in Oregon. These two individuals are generally considered the founders of the Church Growth Movement.

In 1965, the Fuller Theological Seminary, Pasadena, California, invited McGavran to join them as Professor of Missions. He, however, suggested that a Church Growth School of Missions be established, which was implemented. Arthur F. Glasser, another church-growth leader and author, joined the school. In 1966, Ralph Winter also joined the team. He became the historian of the Church Growth Movement.

The Church Growth Movement has increased in prestige and its influence can be felt around the world. It was born out of a crisis situation. Many Christians had become discontent with religion and left their churches in the 1950 s and the 1960s. The closing of Christian missions in China due to the Communist takeover in 1948 was a major setback to the advance of missions. A sense of failure was prevalent among many Christian leaders.

This situation led leaders of the Church Growth Movement to look back and study the principles and practices that had guided missionary endeavors in the past. Numerous church-growth studies were made, dozens of books published, hundreds of seminars conducted, and 
thousands of students of church-growth principles are presently implementing in the field what they have learned. The Church'Growth Movement has created a positive turbulence which has increased evangelism and brought churches to life.

\section{Principles of the Church \\ Growth Movement}

The main principles of the Church Growth Movement, as one encounters them throughout its literature of three decades, can be summarized as follows:

1. The church exists for mission, and mission is defined as church growth. This calls for the addition of individuals to the church.

2. People, with their ethnic and cultural differences, form a mosaic pattern in contemporary pluralistic society. For instance, in New York City there are communities of Jews, Cubans, black Americans, white Europeans, rich, and poor.

3. People must be won in groups (this is McGavran's foremost church-growth principle). This principle applies in the U.S.A. and in Europe as well as in other continents. One should focus on homogeneous units in order to maximize church-growth results.

4. Within the homogeneous units, some persons are receptive to the gospel while others are not. Efforts should be concentrated on those for whom the Holy Spirit is working. 
5. A clear distinction should be made between two stages in the evangelizing process--

(a) discipling - which relates to the conversion of groups of individuals and the establishing of churches.

(b) perfecting - which relates to the province of Christian education.

6. Church growth hinges on the notion that existing churches multiply themselves.

7. Church growth is the responsibility of the laity, and this calls for the mobilization and involvement of the laity.

8. Church growth is the work of the Holy Spirit. However, good stewardship demands that 3-5 percent of a church's budget be set aside for missions in each local church.

9. Church growth calls for bold goals and planning.

10. Church-growth theory claims to be, in essence, theological; that it is not a program, not a methodology, but rather a theological stance.

McGavran's consistent theme throughout his writings on mission is, perhaps, best summed up in this statement:

"A chief and irreplaceable purpose of mission is church n. 1).

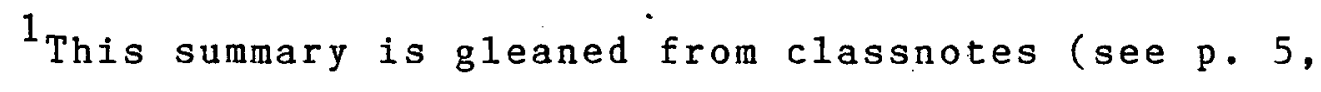


growth." 1 He also insists that "the aim of evangelism is the planting of churches."

The Church Growth Movement distinguishes between three kinds of church growth: biological growth, which "derives from those born into Christian families"; transfer growth, referring to "the increase of certain congregations at the expense of others,"i.e., when individuals of one Christian denomination join another Christian denomination; and conversion growth, "in which those outside the church come to rest their faith intelligently on Jesus Christ and are baptized and 'added to the Lord' in His Church. This is the only kind of growth by which the Good News of salvation can spread to - . earth's remotest bounds."

\section{Reflection upon Church Growth Theory:}

Introduction

Scripture is the rule of faith and practice for God's people. It also provides the people of God with the evangelistic mandate to seek those who are separated from God and proclaim to them God's offer of salvation through Jesus Christ.

p. 32 .

\footnotetext{
$1_{\text {McGavran, Understanding Church Growth }}(1970$ ed.),
}

2 Donald McGavran, "Essential Evangelism: An Open Letter to Dr. J. C. Hoekendijke," W.C C. Occasional Papers, Series 3, no. 2, p. 59.

${ }^{3}$ McGavran, Understanding Church Growth, pp. 98-99. 
God is the first missionary seeking lost individuals to save them. Ever since He called, "Where are you?" (Gen $3: 9)^{1}$, to Adam in the Garden of Eden, God has sought to restore individuals to rightful relationship with Himself. Throughout Scripture are found God's numerous offers of forgiveness and restoration. God desires that all people be saved eternally (2 Pet 3:9; John $3: 16)$. He wants His church to grow.

The Church Growth Movement has accepted this truth as a challenge to uphold and promote the evangelistic mandate among all Christians. However, the Church Growth Movement has its critics. While some of the premises of church-growth thought must be considered positive and helpful, others seem not to be secure and have become the subject of disagreement. As the literature promoting church-growth theory has multiplied, so also has the criticism leveled at the Church Growth Movement. Consideration is given to some of the main ideas as indicated in the following:

(1) Numerical growth

(2) "Discipling" and "teaching"

(3) Gospel proclamation and social services

(4) The role of the pastor and the lay-people

(5) Contributions acknowledged.

${ }^{1}$ All Bible texts are from the Revised Standard Version. 
Numerical Growth

Some critics of the Church Growth Movement have questioned the heavy "emphasis it places upon numerical growth, stating "that quantity and numbers have become an obsession to the neglect of quality growth in godliness. Spiritual growth is sacrificed to numerical growth."

To this charge, Ralph Winter responds: "Numerical growth is not everything; it is not the only way to measure vitality, but it is one way. Numerical increase is normally one index of quality."

Gottfried Oosterwal sees church growth as "the end result of mission" ${ }^{3}$ which is conducted by the church. He suggests that the planting of the church is not the object of mission, rather the church is one of the instruments God uses to accomplish the mission of salvation among those who are without the church and separated from Him. Bringing people into the church does not end the mission, for the perfecting of the saints remains to be completed after baptism.

The tension that seems to exist between the concepts of quantitative growth and qualitative growth is addressed further in chapter 2.

${ }^{1}$ J. R. Quilkin, Meaning of the Church Growth Movement (Chicago: Moody Press, 1974), p. 31 .

2Ralph D. Winter, "Quality or Quantity," in Crucial Issues in Missions Tomorrow, ed. Donald McGavran (Chicago: Moody Press, 1972), pp. 178-187.

${ }^{3}$ Gottfried Oosterwa1, Classnotes, 1982 . 


$$
\text { "Discipling" and "Teaching." }
$$

In Bridges of God, McGavran distinguishes

between the two issues with which the church is constantly confronted--discipling people and perfecting the character of Christians. Dissatisfied with the lack of balance maintained by the churches in this respect, McGavran writes: "There is a constitutional bias toward perfecting; the churches gravitate toward caring for what they have. Their inbuilt nature prefers perfecting to mission.

To improve the balance, the Church Growth Movement, therefore, has vigorously promoted the missionary aspect of the Christian churches. In its emphasis on "discipling," it may have neglected the "teaching" aspect of the Great Commission. To McGavran, "discipling" means adding people to church membership. It seems that in his emphasis on "discipling," in the sense of increasing the number of church members, the emphasis on the equal importance of teaching the new members and building them up in the faith tends to be neglected. It is my opinion that when one receives baptism and the teaching, he is being discipled. Discipling is teaching.

Equally as important as the proclamation of the gospel and the conversion of individuals to Christ is the

${ }^{1}$ Donald McGavran, Bridges of God (New York: Friendship Press, 1955), p. 33 .

2 Ibid., pp. 14-15. 
teaching of the same individuals to live in Christian life, to be nurtured spiritually, and to grow in Christian grace. The one should not be emphasized at the expense of the other.

\section{Gospel Proclamation and \\ Social Services}

Perhaps, the heavy emphasis of the Church Growth

Movement on gospel proclamation somewhat to the neglect of the social concerns has been seen as threatening by some leaders of the mainline churches who stress the need for more social services. At least one prominent leader among the mainline churches is appreciative of McGavran's contribution.

McGavran has seen himself originally in terms of a counter-force to the 'mainline' sending agencies, which have stressed devolution, handing over of initiative to the third world churches, and abdication from evangelistic responsibility in favor of health, education, and welfare-type work. . . As a member of a 'mainline' agency, I feel the need for McGavran's corrective on our heavily unevapgelical and pro-institutional involvements.

Others, like Rene Padilla, who promote the social responsibility of the Christian Church, state:

The Gospel is a message that must be lived. It must be lived out within a definite social context, with all its needs and problems. It must be lived out, in terms of continual selfgiving, motivated by love, in service to one's neighbor. The proclamation of the gospel

${ }^{1}$ A1fred Krass, "Response to Orlando Costas" 'Postscript to the Theological and Methodological Thought of Donald McGavran," in, Orlando Costas, Shattering Critique from the Third World (Wheaton, Il Iinois: Tyndale Publications, n.d.), p. 131. Costas here quotes an unpublished written response by A. Krass to Costas. 
(kerygma) and the demonstration of the gospel through service (diakonia) form an indivisible whole. The one without the other is an incomplete, mutilated gospel and, consequently, contrary to the will of God. From this perspective, it is foolish to ask about the relative importance of evangelism and social responsibility.

Here again it is necessary to exercise caution so as not to overdo one ministry while neglecting another. In the Apostolic Church there were social needs that called for the attention of the apostles, and the preaching of the Word could not be neglected either (Acts 6). Both needs were met.

$$
\text { According to Ellen White, "The Church is God's }
$$

appointed agency for the salvation of men. It was organized for service, and its mission is to carry the gospel to the world."

The Church should not exist for growth only; it exists also for the good of the world. As salt and yeast permeate substances, so Christians should influence society for the eternal good of all. This encompasses both the proclamation of God's Word and attending to physical and social needs of people.

${ }^{1}$ C. Rene Padilla, "A Steep Climb Ahead for Theology in Latin America," Evangelical Missions Quarter1y (Winter 1971): 104-105.

2 Ellen G. White, Acts of the Apostles (Mountain View, California: Pacific Press Publishing Association, 1911), p. 9. 
The Pastor and His Church Members Church-growth theory sees the local pastor as the most important factor in any rapidly growing church. He certainly can be a very important influence for growth or non-growth. However, not everything needs to depend on him. When church members understand and adopt the concept of the priesthood of all believers, congregations can grow and flourish even in the absence of a pastor. The responsibility of every Christian in spreading the gospel is emphasized in Scripture. The apostle Peter declared to Christians of all ages: "You are a chosen race, a royal priesthood, a holy nation, God's own people, that you may declare the wonderful deeds of him who called you out of darkness into his marvelous light" ( 1 Pet 2:9).

The active ministry of lay-people, however, does not eliminate the importance of the pastor to the congregation and its outreach ministry. The best formula for success in church growth is based on the combined effort of the pastor and the church members.

\section{Contributions Acknowledged}

Church-growth theory promotes several precepts with which I agree wholeheartedly. Certainly, proclaimers of the gospel should concentrate on the receptive elements in each community. While these should be cultivated, others should not be neglected. This theory which advocates winning people in groups has biblical precedence,i.e., the 
jailer's family (Acts 16), and the household of Stephanas ( 1 Cor 1:16). Why not seek to win entire groups instead of concentrating only on individuals within groups, as has been done traditionally? Furthermore, one can only agree that churches should replant themselves as they grow, thus extending their mission to greater numbers of people and communities.

No true growth takes place in Christian churches without the presence and work of the Holy Spirit. Church growth in the New Testament sense calls for bold goals and thorough planning. The Church Growth Movement encourages strategic planning and a thrust in evangelism. Generally, Christians have lacked initiative and the acting out of bold plans for church growth. According to Ellen G. White, "our ideas are altogether too narrow. God calls for continual advancement in the work of diffusing light. We must study improved ways and means of reaching the people."

As the Holy Spirit was the Guide, the Teacher, and the Comforter (John 16) for the New Testament Church, so also is He the driving force for the Church today. Christians can afford to make grander goals and bolder plans for outreach and church growth than they generally have done so far. The contributions and challenges of the

${ }^{1}$ Ellen G. White, Christian Service (Washington, D.C.: General Conference of Seventh-day Adventists, 1947), p. 110 . 
Church Growth Movement in this respect should be acknowledged and appreciated for what they are.

\section{Seventh-day Adventists} and Church Growth

Seventh-day Adventists have in recent years shown considerable interest in church growth. This section introduces the main SDA principles of church growth, the mu1ti-dimensional church-growth view, the outreach through institutions, and a new direction in church growth.

The Seventh-day Adventist Theological Seminary in Berrien Springs, Michigan, has set up the Institute of Church Ministry which conducts research in areas related to nurture, outreach, and effectiveness of the church's ministry. Each year a major seminar on church growth is held on the campus of Andrews University. Several small excursions are held elsewhere throughout North America, and even in other countries, with instructors from the Seminary and the General Conference of the Seventh-day Adventist Church in attendance. Frequently, leading figures in the Church Growth Movement have been invited as guest speakers.

\section{The Caring Church}

The Seventh-day Adventist Church has adopted the Caring Church concept. It represents the caring concern for the spiritual welfare of individuals both within and 
outside the church. The five underlying principles of this concern are:

1. a "Christians must mingle with people and effect positive influence on others.

b Christians must all mingle. The Spirit-filled ministry applied to laity and clergy alike.

c Christians must mingle with all kinds of people." Seventh-day Adventists believe they have been given "an everlasting gospel to proclaim to those who dwell on earth, to every nation and tribe and tongue and people" (Rev 14:6).

2. The emphasis is on church mission in the sense of reaching out to others with the gospel of Jesus Christ and providing them with spiritual nurture and Christian fellowship. "The caring church judges every church activity by whether it leads people to spiritual growth and eternal life." To accomplish this task, "the congregation must assign primary importance to the gospel commission."

3. The church is viewed as holistic in its ministry. One ministry should not be neglected due to overemphasis on another.

4. The church's focus should be on people.

5. The church must recognize "people flow." "People generally go from one activity to another in a logical sequence, developing interest and commitment as they move along. When a church 
understands that orderly process and develops programs that cooperate with it, the pathway from unbelief to salvation is easier to follow, and the result is a higher degree of success."

\section{Multi-dimensional Church Growth}

Oosterwal sees church growth as a multi-dimensional phenomena.

The Church of Jesus Christ has many dimensions: it is God's messenger and instrument of His grace; a body of believers and an organization; a system of belief and sign of God's kingdom. In fact, the New Testament uses a hundred images and metaphores to describe this multi-dimensional nature of the church. Each of these dimensions needs the other and supports the other;

challenges the other and corrects the other. Together, they all form an indivisible whole. Church"growth, therefore, is also a multi-dimensional phenomenon, and should always be approached holistically.

According to Roger L. Dudley and Des Cummings, Jr.,

"The growing church is the caring church--the one that finds and meets the needs of the people around it." ${ }^{3}$ It is their contention that as one must both exhale and inhale in order to maintain his physical we11-being, so also must the church be involved in both outreach and

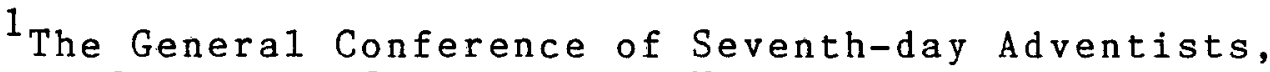
The Caring Church: A Strategy for North America (Washington, D. C.: The General Conference of Seventhday Adventists, 1983).

${ }^{2}$ Gottfried Oosterwal, "Introduction" for MSSN 600 Seminar in Church Growth, Andrews University, Berrien Springs, Michigan, 1984. (Mimeographed.)

${ }^{3}$ Roger Dudley and Des Cummings, Jr., Adventures in Church Growth (Washington, D. C.: Review \& Herald Publishing Association, 1983), pp. 10-11. 
nurture. On this view it is "a false dichotomy to set evangelism above body-building ministries. Both are absolutely essential. . . It is not outreach versus nurture, but rather nurture to make outreach possible and to mature the spiritual lives of the new believers."

Outreach through Institutions

The history of Adventist missions reveals that Adventists began their work in many countries by establishing schools and other institutions. Frequently, this led to a reliance on institutions as the chief instruments for church growth.

Seventh-day Adventists are known as a missionaryminded church. For many years they have been among those denominations sending large numbers of missionaries to other lands. However, this was not always:so, and the number of missionaries is now declining, in part, because of increased indigenization of the church in other countries.

As Adventist missionaries in the late 1800 s opened up mission work in many countries, they approached their mission, at first, as evangelists. Enthusiasm for spreading the gospel ran high in Adventist circles. Richard Schwarz refers to the missionary fervor among Adventists around the turn of the century as 'Mission

$1_{\text {Ibid., p. } 27 .}$ 
Advance. ${ }^{1}$ Soon, however, SDA missionaries adopted the traditional missionary strategy of the mainline churches, that of establishing and operating Christian schools, not only as opening wedges but also as the chief method of outreach. This trend was abetted in many countries by government aid to the schools. It provided much needed funds which missionaries of most faiths welcomed.

$$
\text { According to George R. Knight, }
$$

Adventists began to establish schools around the world so that workers could be trained in their home fields. By 1900 , therefore, not only had Adventist educational institutions greatly expanded in qumber, but the system also had been internationalized.

Knight further states:

The magnitude of this whole process was compounded by unprecedented institutional development during the 1890s. Besides churches and schools, Adventists developed hospitals, publishing houses and eventually (to a lesser extent) health food factories in the United States and overseas. Thus the schools were called upon to supply ever larger numbers of institutional workers, in addition to evangelistic workers.

What began as a 'Mission Advance' in a fervent desire to speedily proclaim the gospel to as many people as possible, soon slowed down as missionaries occupied themselves with matters of operating and maintaining institutions of various kinds. Adventist mission has

${ }^{1}$ Richard W. Schwarz, Light Bearers to the Remnant (Mountain View, California: Pacific Press Publishing Association, 1979), p. 214.

2 George R. Knight, "Spiritual Revival and Educational Experience," Adventist Review, March 29, 1984 , p. 11 .

$$
{ }^{3} \text { Ibid., p. } 7 .
$$


increasingly become institutionalized. With increased attention to institutions, there is generally a tendency to neglect the work of direct evangelism and sometimes even the provision of spiritual nurture to the believers. A case in point is the SDA mission in China. Before the Communist take-over (in 1948), 57.7 percent of the mission funds for China were reportedly invested in institutions, another 40 percent went to house missionaries, and only 2.3 percent to local churches and evangelism. When missionaries had to leave the country, the institutions were taken over by the government. Fortunately, the church survived the adversity. It is not possible for the SDA Church in China to operate institutions of any kind now. Presently, it is experiencing growth "with thousands of baptisms and numerous chapels built, owing to lay witnessing." ${ }^{2}$ This is evidence of the possibilities inherent in grass-roots and home-church evangelism.

Properly conducted institutions have their place in mission. The

"stated purpose of Battle Creek College was to train for mission service at home and in foreign fields. The first great motivation for Adventist schooling had been

${ }^{1}$ David Lin, "Years of Heartbreak: Lessons for Missions by a China Insider," Spectrum 7, no. 3 (1975): 25. Mr. Lin was the Secretary of the China Division of the Seventh-day Adventist Church at the time of the Communist take-over.

2 Eugene F. Durand, "Around the Wor $1 \mathrm{~d}$ in $1984, "$ Adventist Review, December 27,1984, p. 7 . 
rooted in mission. The same was true in the 1890 s of the second great thrust of Adventist education."

McGavran points out that the mainline churches sending missionaries to countries around the world followed the same pattern in carrying out their foreign missions. In spite of their diversity in doctrines, they all began their missions more or less the same way. They "carried on schools as an essential part of their evangelistic work." ${ }^{2}$ It was believed that the "correct way to Christianize" was "through prolonged schooling." It was held that the "chief task of missions and the only sound way to proceed" was through "the establishment of mission stations, dispensaries, hospitals, schools, and--in connection with them--churches."

McGavran refers to this approach to mission as the "school-approach church growth." Speaking of the school-approach in Zimbabwe and Zambia, he calls for new kinds of church growth in these countries. "A simplistic view which imagines that the church will grow according to the present pattern is not merely useless: it is dangerous." 6 Zeroing in on the school-approach, McGavran

${ }^{1}$ Knight, "Spiritual Revival," p. 11. Battle Creek College was a SDA college, established in 1874, in Battle Creek, Michigan.

${ }^{2}$ McGavran, Understanding Church Growth (1980 edition), p. 13 .

$$
\begin{array}{ll}
{ }^{3} \text { Ibid. } & { }^{4} \text { Ibid., p. } 14 . \\
{ }^{5} \text { Ibid., p. 13. } & { }^{6} \text { Ibid., p. } 15 .
\end{array}
$$


delivers his judgment: "Any policy that leaves churches and mission satisfied with the glacial advance which is a11 the school-approach can deliver, is suicidal."

However, the school-approach should be given credit for its contributions to church growth when circumstances are ripe for this kind of outreach emphasis. Presently, the emphasis on Christian education in the SDA Church in Iceland does not seem to be the most productive method of church growth.

Having committed itself and its mission purpose to maintain institutions, educational and medical, these became so demanding that they absorbed almost all the resources of the church. This seems to have been at the expense of other branches of the ministry. Little has been left for the more direct kinds of evangelistic outreach. Furthermore, big institutions tend to extend their roots of influence to ensure self-perpetuation. An institution may develop to the point where it exists for its own sake. When this happens to a denominational institution, the church's ministry is likely to suffer. Grimley and Robinson discuss the school-approach issue in their study of church growth in Nigeria. They enumerate some advantages to this type of outreach, i.e., the creation of an atmosphere conducive to Christian growth and understanding after conversion. Among the 
negative aspects, they emphasize the dangers of the church not seeking converts from the masses; the efforts and the resources of the Church being concentrated on a few; and the great difficulty in reversing the school-approach once it has been initiated. "The schools continually grow and expand, demanding increasingly more personnel and resources."

Changing the Course?

Christian churches have always had the dual responsibility of nurturing and encouraging those within their fold and conducting outreach programs. In the history of christianity are many examples of such extreme concentration on one of these poles that the other is neglected. Likewise, the focus of the Adventist Church may be so much directed to one form of outreach (institutions, i.e. hospitals and schools) that other forms of outreach suffer (i.e. public evangelism and the training of lay-people for soulwinning activities).

The big question for SDA church leaders to ponder at this time is how they are going to involve the laypeople in an active outreach ministry. Des Cummings, Jr., and Roger Dudley in an interview with Peter Wagner expressed the general frustration felt among SDA pastors

${ }^{1}$ John B. Grimley and Gordon E. Robinson, Church Growth in Central and Southern Nigeria (Grand Rapids, Michigan: William B. Eerdmans Publishing Company, 1966), p. 321 . 
over the non-involvement of the laity in personal. ministry. They said: "In our studies of the Seventh-day Adventist pastors, the number one frustration is how to motivate the laity into ministry. How do you bring them back from a position where, obviously over time, they have been taught to sit back and let the pastor do it?" ${ }^{1}$ The answer to this question may be found in the proper training of the laity; the pastor leading the people into experiencing the thrill of giving Bible studies and personal testimonies for their faith; and the delegation of responsibility.

The leadership of the Seventh-day Adventist Church is now realizing the potential for greater church growth latent in the largely untapped resources of the talents and spiritual gifts among the laity. The SDA churchgrowth strategists are increasingly turning their attention to the laity.

\section{Lessons for Adventists in Iceland}

The Seventh-day Adventist Church in Iceland is in urgent need of a new direction, a different emphasis, in its outreach program if positive, steady growth is to become a reality in future years. Perhaps, a look at what growing churches elsewhere are doing could serve as a starting point.

\footnotetext{
${ }^{1}$ Northern Light, 34 (May 1984):3.
} 
Browsing through church-growth literature one's attention is soon drawn to the prominence given to small groups in present day church-growth strategy. Leaders of growing churches are quick to point to the creation of small Bible study groups and fellowship groups as an important basis for planting new churches. Lyle E. Schaller, an author of many books on church life and growth, writes:

Thousands of congregations are intentionally organized around the development of a large and ever-growing number of small groups such as Bible study groups, adult Sunday school classes, circles in the women's organization, youth groups, prayer circles, recreational teams, hobby groups, and mission task forces.

This is one of the healthiest and most productive organizing principles on this list. It is widely used in rapidly growing and strongly evangelistic urban churches. The larger the congregation and the more central this organizing principle is in the life of that congregation, the more essential it is that the church be adequately staffed to nurture, reinforce and maintain the group life.

James H. Montgomery and Donald A. McGavran continue

in the same vain:

Many of our churches today grew out of home Bible studies conducted by ministers and in most cases by laymen. Existing churches are growing because their members are engaged in evangelistic Bible studies in offices, campuses and homes. It is one of the surest ways of carrying out the Great Commission and having rapid church growth.

${ }^{1}$ Lyle E. Schaller, Assimilating New Members (Nashville, Tennessee: Abirigdon Press, 1978), pp. 29-30.

2 James H. Montgomery and Donald A. McGavran, The Discipling of a Nation (Pasadena, California: Global Church Growth Bulletin, Publishers, 1980), p. 61. 
Montgomery and McGavran counsel church leaders to learn from what Seventh-day Adventists are doing in the Philippines. "They have become the largest (Protestant) denomination in the country and add more new members each year than many denominations have gained in their whole history in the Philippines:" These church-growth specialists place their finger on what they consider the key to the success of Adventists in the Philippines:

Few others have been as successful as Adventists in mobilizing and training their laity for personal work, house-to-house visitation and Bible marking classes. . - Each new convert is immediately coached on some key verses and sent out to begin witnessing.

Atheistic organizations have also realized the importance of forming small groups to increase their numbers. Writing about Communism, Douglas Hyde maintains that the "Party's organization, as is well known, is based upon small groups or 'cells'. These are its 'basic units'. Through them the Party does its work at grassroots level. Or, to change the metaphor, they are Communism's cutting edge."

Another imperative for successful church-growth strategy is the planting of new churches. Emphasizing the importance of planting new churches, Montgomery and McGavran again point to the Adventist growth in the

$$
\begin{aligned}
& { }^{1} \text { Ibid. } \\
& { }^{2} \text { Ibid., p. } 112 . \\
& { }^{3} \text { Douglas Hyde, Dedication and Leadership (South }
\end{aligned}
$$
Bend, Indiana: Notre Dame University, 1971), p. 143. 
Philippines, maintaining that it is based on what they refer to as "church planting priorities."

An Adventist pioneer, Ellen G. White, presents Adventists with this challenge regarding the planting of new churches:

There was spread out before me city after city in need of evangelistic labors. If diligent effort had been given to the work of making known the truth for this time in the cities that are unwarned, they would not be as impenitent as they are. From the light that has been given me I know that we might have had today thousands more rejoicing in the truth if the work had been carried forwąrd as the situation demands, in many aggressive lines.

Furthermore, White states: "The places in which the truth has never been proclaimed are the best places in which to work. The truth is to take possession of the will of those who have never before heard it...."

Charles L. Chaney, a prominent leader in the church-growth movement, also promotes the strategy of planting new churches:

With very few exceptions, the rate at which a church can win people from the world to faith in Christ, baptize them, and incorporate them into its fellowship

${ }^{1}$ The Discipling of a Nation, p. 110.

${ }^{2}$ Ellen G. White, Letter 94a, June 6, 1909 , addressed to "Brethren and Sisters in Washington" while Mrs. White was in Washington (Berrien Springs, Michigan: Ellen G. White Estate).

${ }^{3}$ Ellen G. White, Letter 106, May 20, 1903, written at Healdsburg, California, and addressed to "The General Conference Committee" of the Seventh-day Adventists (Berrien Springs, Michigan: E1len G. White Estate). 
will significantly increase when that church begins to meet in more than one place.

Perhaps the experience of the Church of the

Nazarene offers a lesson Adventists in Iceland would do well to consider. There are some similarities between the two churches as far as their emphasis on outreach is concerned.

The Church of the Nazarene had its beginning in the United States of America in 1895, when Dr. Phineas F. Bresee launched his personal ministry among people in the West, organizing them into church fellowships. In the first thirteen years, 228 congregations were organized, and the first twenty-five years of the denomination saw a twelve-fold growth. "A notable feature of this crusade was its massive involvement of lay-people who had been trained in personal evangelism, revival campaigns and church planting."

However, this phenomenal growth rate later began to slow down, and in the 1970s it was "grinding to a halt." Dr. Raymond W. Hurn, Director of the Church Extension Ministries for the Church of the Nazarene, explains the cause for the negative development:

${ }^{1}$ Charles L. Chaney and Ron S. Lewis, Design for Church Growth (Nashville, Tennessee: Broadman Press, 1977), p. 143.

2 Global Church Growth Bulletin, vol. 19, no. 1 , 1982 , p. 160. "It's Back to Church Planting for the Nazarenes" by Raymond W. Hurn. 
What had gone wrong? Later reflection would reveal that a subtle shift in denominational priorities had begun to occur. Whereas early-day district superintendents had risen to prominence as church planting evangelists, their modern counterparts had their energies drained away in maintenance of denominational machinery. . . It wasn't until the denomination returned to the method that produced phenomenal growth in the first 50 years that their downward trend began to be reversed. If denominations all over the world will learn this same lesson, the discipling of whole peoples and countries will not be far behind.

For the first twenty-five years, the Church of the Nazarene had an average annual growth rate of 50 percent; during the next twenty-five years the average annual growth rate dropped to 9.5 percent. But by 1978 and 1979 the annual growth rate had plummeted down to 1.5 2 percent.

Most towns in Iceland do not have an Adventist presence. For the city of Reykjavik and its suburbs, there is only one church building and one congregation. The church building is located in an old section near the center of the city. As the city and its suburbs continue to expand away from the Adventist Church center, more and more of the population live in increasingly more distant places. Other denominations cope with this population movement by expanding their church activities to where the people live. The Lutheran State Church has faithfully followed this practice. The Pentecostal Church has

\footnotetext{
${ }^{1}$ Ibid.

2 Ibid.
} 
already established an extension center in the large and populous Breidholt, one of the newest sections of the city. The Catholic Church has secured land in Breidholt, where it will soon build another church.

Present1y, the Seventh-day Adventist Church has failed to follow suit. It seems obvious that any churchgrowth strategy implemented by the SDA Church in the city of Reykjavik should have on its agenda the planting of new churches, not only within the city but also in several suburbs and nearby towns. 


\section{THEOLOGICAL CONSIDERATIONS}

FOR CHURCH GROWTH

This chapter concerns certain theological implications of church-growth theory. Individual sections focus on such subjects as: theological justification for church growth; quantitative growth and qualitative growth; God's work and man's work in church growth; and the role of the Holy Spirit in church growth.

\section{Justification for Church Growth}

The Scripture deals some with the subject of growth and decline of the Christian Church. Reading the Bible from Genesis to Revelation, one can hardly fail to observe the importance given to the increase of God's people both in numbers and in Christian virtue.

The Lord's command in the Great Commission (Matt 28:19-20)--"Make disciples of all nations"--presupposes that the greater the number of nations represented by God's people, the more disciples there will be. This premise becomes even more evident as greater numbers of people from each nation become disciples. Fidelity in discipleship is also called for: "Teaching them to observe 
all that I have commanded you." It is not surprising, therefore, that the parting words of Jesus Christ, as Matthew recorded them, have become the marching orders for the Church Growth Movement.

Go therefore and make disciples of all nations, baptizing them in the name of the Father and of the Son and of the Holy Spirit, teaching them to observe all that I have commanded you. (Matt 28:19-20)

The idea of growth was introduced by the Creator Himself at the beginning of mankind. Addressing Adam and Eve, God instructed them: "Be fruitful and multiply, and fill the earth. . ." (Gen $1: 28$ ). When man sinned by rebelling against God's authority, he separated himself from God (Isa 59:2). Naturally, God no longer favored the increase of people who were defiant of Him.

Fortunately, God had a plan through which salvation from sins and eternal death (John $3: 16$ ) is made available to all sinners. To accomplish this mission of salvation, God calls individuals to actively witness about His love for humankind, His salvific acts, and eschatological 1 events. It is to this effect that God constantly calls individuals to accept His offer of grace and to live righteously in an evil word. This again implies growth; the more, the better.

Elsewhere, the Scriptures give further evidence of God's desire for a multitude of loyal subjects. To

${ }^{1}$ See Gen $12: 3 ; 1$ Kgs $8: 41-43,60$; Matt 24 and 25. 
Abraham He declared: "Look toward heaven, and number the stars, if you are able to number them. . so shall your descendents be" (Gen 15:5). This statement might be an indication of church-growth sentiment. One should keep in mind that God here was calling a nation into existence which was to grow not only in numbers but also in grace and dedication to God.

Blauw calls attention to the "striking peculiarity that both the synoptic Gospels and the Gospel of John culminate in the pronouncement of the resurrection and the call to mission emerging from it." ${ }^{1}$ He further comments: "In this 'going forth' the whole apostleship of the Christian church is clearly indicated; the making of disciples can happen only in a movement of the disciples of Christ towards al1 nations."

God Himself, the Creator and the Redeemer, is the pioneer missionary, the proclaimer of salvation to lost people. Not only did He introduce His plan of salvation for lost mankind as soon as man had strayed away from Him (Gen 3:15), but God also became man's substitute in death (John $3: 16$ ). In His death He would draw all men to Himself (John 12:32).

\section{Johannes Blauw, The Missionary Nature of the} Church (Grand Rapids, Michigan: William B. Eerdmans Publishing Company, 1962) p. 83.

$$
{ }^{2} \text { Ibid., p. } 86 \text {. }
$$


It is this drawing of people that church growth is ali about. And it is for this purpose that the Christian church exists. The apostle Peter gives a vivid description of God's church, a description of what its members once were, and what they are now.

But you are a chosen race, a royal priesthood, a holy nation, God's own people, that you may declare the wonderful deeds of him who called you out of darkness into this marvelous 1ight. Once you were no people but now you are God's people; once you had not received mercy but now you have received mercy. ( 1 Pet 2:9-10)

These descriptive phrases, "a chosen race, a royal priesthood, a holy nation, God's own people," reveal how precious the church is in God's sight. Blauw maintains that Christians are a chosen race for a specific purpose, "to proclaim the great acts of God in the world." The disciples of Christ in all ages endeavor to make known to others God's acts in creation, His acts of deliverance in times of crises, and the work of redemption through Jesus Christ. Looking to the future, they also warn mankind of judgment and the impending end of the world.

Furthermore, the members of the Christian Church are said to be "a royal priesthood," thus establishing the priesthood of the believers. When Christians make their baptismal covenant with the Lord, they are baptized, not to become just another member of the church, but for service. This service is demonstrated by the active involvement in the church's proclamation of the good news

${ }^{1}$ Ibid., p. 29 
of salvation made available to all people. Those who receive and accept God's grace receive and accept the priesthood of the believers and begin to serve others. Blauw suggests that "the Gentiles, unholy in themselves, have been sanctified by coming to Christ. By this means they have separated themselves from others, the disobedient, and now stand in a positive relation to God." 1 This represents growth in the Kingdom of God. Peter's descriptive language is impressive in the light of the background of the Christians he is addressing. Formerly they were in "darkness" and "were no people" and "had not received mercy." Al1 that was past experience. They were now in "his marvelous light" as "God's own people."

This experience must have been quite visible to many outside the congregation who must also have desired to have this joy in the Lord, for Luke comments: "And the Lord added to their number day by day those who were being saved" (Acts 2:47). The apost1e Paul traveled widely in many countries and labored hard in raising new churches (Acts 13 to 21). But Paul sought to do more than plant churches and swell the ranks of Christians. Through his letters he constantly endeavored to improve the spiritual experience of the believers. "Be fruitful in holiness" (Rom 6:22), he wrote to the Christians in Rome; and he

$$
1_{\text {Ibid., p. } 131}
$$


instructed the saints in Ephesus: "grow up in every way into him who is the head, into Christ" (Eph 4:15). The believers in Thessalonica received the message: "May the God of peace himself sanctify you wholly; and may your spirit and soul and body be kept sound and blameless at the coming of your Lord Jesus Christ ( 1 Thess 5:23). Peter also emphasized the point that Christians must experience growth in their collective virtues. "So put away all malice and all guile and insincerity and envy and all slander. Like newborn babes, long for the pure spiritual milk, that by it you may grow up to salvation; for you have tasted the kindness of the Lord" (1 Pet $2: 1-3)$. He further wrote: "But grow in the grace and knowledge of our Lord and Savior Jesus Christ" (2 Pet $3: 18)$.

\section{Qualitative Growth and Quantitative Growth}

The focus of this section is the relationship that exists between the concepts of quantitative growth and qualitative growth. The question is sometimes asked: Is the persuance of the one more important than the other in achieving church growth?

Some church leaders go all out in their drive to increase the number of parishioners. Others contend it is not numbers that matter but the quality of discipleship.

The authors of the Lausanne Covenant emphasize: "We have sometimes pursued church growth at the expense of 
church depth and divorced evangelism from Christian nurture." But there need not be a pursuance of the one at the expense of the other. In fact, each can complement the other, as Oosterwal points out: "Qualitative growth leads to quantitative growth." In order to grow in numbers, the presence of virtuous discipleship is necessary .

Ralph Winter continues in the same vain:

Every task has dimensions of both quality and quantity. - A1l quantitative measures are measurements of certain qualities. . . Highly important qualities have measurable dimensions. The proper way to look at quantitative measurements is to regard them--properly handled--as reliable indications of qualities.

In church growth, quantity and quality go together. One without the other is incomplete. But while the numbering of disciples is an objective process and usually not a difficult task, the measuring of Christian character is more difficult for it is likely to be a highly subjective exercise.

There are certain dangers inherent in attempts to measure the spirituality of the community of faith. While

${ }^{1}$ J.D. Douglas, ed., Let the Earth Hear His Voice (Minneapolis, Minnesota: Wor1d Wide Publications, 1975), p. 245 .

${ }^{2}$ Gottfried Oosterwal, "The Seventh-day Adventist Church in the World Today," in Servants for Christ, ed. Robert E. Firth (Berrien Springs, Michigan: Andrews University Press, 1980), p. 6 .

${ }^{3}$ Ralph Winter, Penetrating the Last Frontier (South Pasadena, California: William Carey Library, 1979), p. 178 . 
some may be inclined to go too far in assessing the Christian experience of a congregation, others tend to succumb to the opposite danger of too relaxed an attitude towards the Christian standard upheld by a church. Israel learned from hard experience what difficulties the "mixed multitude" (Exod 12:38) that followed out of Egypt could inflict upon the nation. Moses referred to them as "the rabble" (Num 11:4). Later, "all those of foreign descent" were separated from Israel (Neh 13:3). God desired to have His people free from complaining, rebellious attitude of people who were not truly loyal to Him.

A. R. Tippett writes: "Quantitatively, the church is expected to grow in bulk and strength." ${ }^{1}$ But he stresses the point that the "motive of numbering is pastoral care." "Mere numerical growth" without repenting, believing, and confession "is in vain."

Speaking of both numerical increase and spiritual growth, Orlando Costas writes:

The term "growth" suggests mobility and change; it indicates a dynamic reality. Where there is growth, there is increase, expansion, development, and multiplication or reproduction. Where there is growth there is also mutation, transformation, renewal, and creativity. There is thus no growth without change. Where there is no growth, there is stagnation, inertia, illness, and potential decay. Immobility and stasis

${ }^{1}$ A. R. Tippett, Church Growth and the Word of God (Grand Rapids, Michigan: William B. Eerdmans Publishing Company, 1970) p. 25.

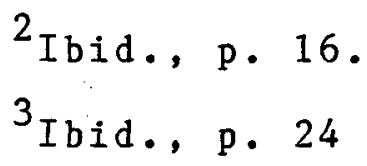


are warping lights; they are signs of the absence of growth.

According to God's Word, He expects the content of the Christian experience to grow day by day. He also expects that the number of the members of His church continue to increase till the end of time.

A congregation that is devoid of spiritual experience is empty and unattractive. It has lost its appeal. On the other hand, a growing church serves its intended purpose in this world as it receives new members and nurtures and guides them into ever richer experience and joy in the Lord. Such a congregation will have many ready and waiting for the return of the Lord when He comes to receive His people.

\section{God's Work and Man's Work in Church Growth}

Christians acknowledge that salvation of sinners comes from God. But some are perplexed over the question of what constitutes God's responsibility and what man's duty in the proclamation of the gospel. In this section attention is focused on this issue.

Dr. John C. Ryland (a Baptist minister in England, died 1792) is quoted as saying: "Young man sit down: when God pleases to convert the heathen, He will do so without

10rlando E. Costas, "A Wholistic Concept of Church Growth," in Exploring Church Growth, ed., Wilbert R. Shenk (Grand Rapids, Michigan: Eerdmans, 1983), p. 96. 
your aid or mine." ${ }^{1}$ However, mission strategists must be ever aware of certain dangers that are likely to result from such a view. One is the tendency to leave al1 the work of salvation for others entirely to God. Some may think there is nothing they can do about the salvation of others. According to this view, God has predestined the fate of each individual. This is determinism.

Certainly God is omnipotent. He is also omniscient and omnipresent. But until one truly understands what the Gospel Commission is all about, he/she may not be able to solve the apparent contradiction between God's sovereignty and the responsibility God places upon the sinful to bring other sinners to Christ. It is one thing to be aware of God's sovereignty, and quite another to accept God's invitation to become His co-laborer for the salvation of sinners. In His plan of salvation, the omnipotent God has seen fit to give certain tasks and responsibilities to human beings. The proclamation of the Gospel has been entrusted to humankind.

On the other hand, there are those who act as if the eternal welfare of their neighbors depended entirely upon their efforts. They stop at nothing until such "Iost" ones have been brought into church fellowship, as if belonging to a church were assurance of salvation. This is naturalism.

${ }^{1}$ F. D. Walker, William Carey (Chicago: Moody Press, 1925), p. 54 . 
William Carey contends that "if it is the duty of all men to believe the Gospe1. . then it is the duty of those who are entrusted with the Gospel to endeavor to make it known among a11 nations."

It may seem there is not much a sinful human being can do for another sinful being. However, we might take a clue from Israel's experience. During Israel's wilderness wanderings, the presence of God was constantly visible, in form of a pillar of cloud by day and pillar of fire by night. One might draw the conclusion that Israel was in no need of additional help or guidance in the wilderness, least of all from a sinful man, and a Midianite at that. Yet, when Hobab the Midianite visited the camp, he was recruited by Moses to serve as a guide through the desert (Num 10:29-32). This incident seems to underscore the responsibility of God's people to seek the best human help available for every undertaking. Human beings are called to work with God. This is particularly true in the proclamation of the Gospel.

Preaching the Gospel means bringing good news to people, but it also involves the task of warning them of coming judgment and destruction of this world. The prophet Ezekiel speaks in no uncertain terms of man's responsibility to warn others.

The word of the Lord came to me: 'Son of Man, speak to your people and say to them, If I bring the sword upon

${ }^{1}$ Ibid., p. 53 
a land, and the people of the land take a man from among them, and make him their watchman; and if he sees the sword coming upon the land and blows the trumpet and warns the people; then if any one who hears the sound of the trumpet does not take warning, and the sword comes and takes him away, his blood shall be upon his own head. He heard the sound of the trumpet, and did not take warning; his blood shall be upon himself. But if he had taken warning, he would have saved his life. But if the watchman sees the sword coming and does not blow the trumpet, so that the people are not warned, and the sword comes, and take any one of them; that man is taken away in his iniquity, but his blood I will require at the watchman's hand.

So you, son of man, I have made a watchman for the house of Israel; whenever you hear a word from my mouth, you shall give them warning from me. If I say to the wicked, 0 wicked man, you shall surely die, and you do not speak to warn the wicked to turn from his way, that wicked man shall die in his iniquity, but his blood I will require at your hand. But if you warn the wicked to turn from his way, and he does not turn from his way; he shall die in his iniquity, but you will have saved your 1ife. (Ezek 33:1-9)

Not all people are responsive to the proclamation of the Gospel all the time. But in most places, most of the time, there are some segments of each society receptive to the Gospe1. The sovereign Lord has commissioned His disciples in all ages to teach, to baptize, to make disciples "to the end of the earth."

The Church Growth Movement has taken this profound truth of God's sovereignty and translated it into a dynamic missionary axiom: 'conceptrate on the responsive elements of society!'

Church-growth theory promotes the strategy of leading people to Christ while they are winnable. Glasser

${ }^{1}$ Arthur F. Glasser, "Church Growth and Theology," in God, Man and Church Growth, ed. Alan R. Tippett (Grand Rapids, Michigan: William B. Eerdmans Publishing Company, 1976), p. 57 . 
capitalizes on this strategy in his treatment of God's sovereignty and man's responsibility:

So then, we are deeply persuaded that God is sovereign in His dealing with men. He makes them winnable. There is a time when His Spirit is peculiarly active in the hearts of men. They become 'ripe unto harvest.' It is the task of $\mathrm{His}$ reapers to translate this reality into a strategy for mission.

God desires to save all sinners. He has made all provisions necessary for man to have eternal life. Man can contribute nothing to his own salvation except to accept God's gift of eternal life. As individuals accept Jesus Christ as their Savior and become His disciples, they in turn are given the responsibility of proclaiming the Gospel of salvation to others. Thus humans become the bearers of good news. It is in this sense that God and humans work together for the salvation of all people.

\section{$\frac{\text { The Role of the Holy Spirit }}{\text { in Church Growth }}$}

The Holy Spirit plays a vital role in the spiritual health of the Christian Church as well as in preparing and leading the church in mission advance. In fact, the church cannot experience growth without the presence and influence of the Spirit of God.

The Spirit of God was present and actively engaged in the creation of the world (Gen 1:2). This observation takes on even greater significance in the light of His

${ }^{1}$ Ibid., p. 58 . 
activities in New Testament times, and ever since. As Christ ascended to heaven His first act as King in glory "was the creation of the church by the sending forth of the Holy Spirit." 1

Furthermore, in Boer's words, "He is the originator and principle of the new life in Christ. . . In recreation as in creation, the life-giving principle is the Holy Spirit of God." ${ }^{2}$ Boer also correctly states that the "correlation between the Spirit as Creator and the Spirit as Redeemer is much overlooked in theology." ${ }^{3}$ In a beautiful way, Boer asserts:

The Creator, still cherishing his Creation, though fallen, has become Restorer, Healer, Reconciler. His instrument is Christ, his effectuator is the Redeemer Spirit. The Creator Spirit, while fully retaining his integrity as Creator, has also become the Redeemer Spirit.

It is in this capacity, as Redeemer, that the Spirit plays a critical role in church growth.

But as church leaders occupy themselves with the study of church growth, they can become so enthusiastic about measurements, demographic studies, and analysis that the part of the divine may sometimes be left out. Yet,

\section{${ }^{1}$ Arthur F. Glasser and Donald McGavran,} Contemporary Theologies of Mission (Grand Rapids, Michigan: Baker Book House, 1983), p. 40.

2 Harry R. Boer, "The Holy Spirit and Church Growth" in Exploring Church Growth, ed. Wilbert R. Shenk (Grand Rapids, Michigan: William B. Eerdmans Publishing Company, 1983), p. 250 .

${ }^{3}$ Ibid. ${ }^{4}$ Douglas, ed., p. 247 . 
the Lord is very emphatic in His declaration: "Apart from me you can do nothing" (John 15:5).

The necessity for this dependence on the Holy

Spirit for outreach and church growth is further

emphasized in the Lausanne Covenant: "The Holy Spirit is a missionary spirit; thus evangelism should arise spontaneously from a Spirit-filled church. A church that is not a missionary church is contradicting itself and quenching the Spirit."

With the descent of the Spirit upon the disciples on the day of Pentecost, the missionary work began in earnest. Now, as then, the Spirit brings revival among the people of God, producing repentance and confession. Renewed in power of heart and mind and missionary fervor, the people are given the basis for church growth.

The Spirit wrought a remarkable change in the lives of the disciples on the day of Pentecost. During the relatively short time since the death of their Master, they had more or less kept to themselves. They may have feared for their lives, and their courage for outreach was at an all-time low. They used the time for reflection and prayer. Then suddenly, according to Christ's promises of providing them with another Counselor (John 14 to 16), they were empowered by the Holy Spirit (Acts 2). Gone were their fears and hesitations. They now became bold

$$
{ }^{1} \text { Douglas, ed., p. } 247 .
$$


witnesses for their Lord and Savior. They commanded respect and their proclamations and influence spread like wildfire "to the end of the earth."

John T. Seamands aptly describes the consequences

of the Spirit's descent upon the disciples:

The secret of this dynamic lay movement which led to spectacular church growth was that Christ, through the Holy Spirit, had transformed their lives and endued them with courage and power to witness effectively for their Lord. Without this enduement they would have failed. With it, nothing could stop them.

The Spirit leads, instructs, admonishes, and gives gifts and power to human beings who place themselves under His control. In this way the Spirit was given opportunity to play a major role in the outreach and growth of the early church. Furthermore, Paul reminded the elders of the church at Ephesus that the Holy Spirit had made them guardians of the flock (Acts 20:28). And Scripture reveals how closely human beings are to work together with the Spirit in the upbuilding and strengthening of the Christian Church: "It has seemed good to the Holy Spirit and to us to lay upon you no greater burden than these necessary things" (Acts 15:28). Melvin Hodges points out that as the Spirit sent forth the disciples, "converts were won and churches

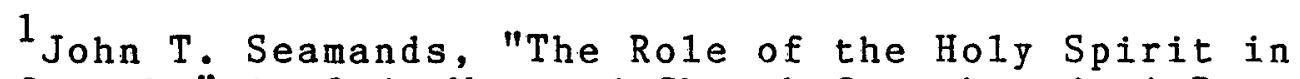
Church Growth," in God, Man and Church Growth, ed. A.R. Tippett (Grand Rapids, Michigan: William B. Eerdmans Publishing Company, 1973), p. 103. 
established as naturally as night follows day. It could be no other way."

Luke's account (Acts 16:6-15) of the Spirit's interference with Paul's travel plans during one of his missionary journeys reveals to what extent the Holy Spirit will go in working with, and on behalf of, God's people. The Spirit guided Paul to places and people where, obviously, his ministry would be most fruitful.

Scripture shows that the apostolic Church was totally dependent upon the Holy Spirit in molding the character of the disciples and equipping them for service, then in leading the Church in a great missionary advance in many countries. So it should be now, and to the end of time.

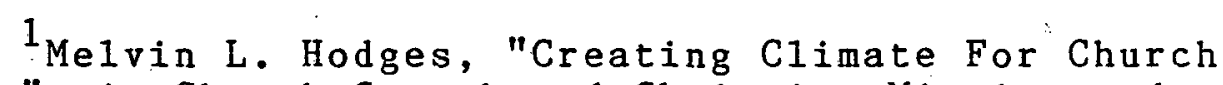
Growth," in Church Growth and Christian Mission, ed. Donald McGavran (New York: Harper and Row, 1965), p. 30. 
CHAPTER III

\section{ICELAND - HISTORICAL BACKGROUND}

\section{The Country and the People}

Introduction

Iceland, frequently referred to as "the saga island," the "dreamland of the north," or "the land of the midnight sun," is one of the great stepping stones between Europe and North America. A sparsely populated country of 40,000 square miles, it lies in the North Atlantic barely touching the Arctic Circle, and measuring 298 miles from east to west and 194 miles from north to south.

Geographically, it is closer to the American continent, but its people and culture must be considered European. Icelanders have an old and a remarkable history. It is a story of Vikings, of hardship, and of struggle for survival against the elements of nature, plagues, and foreign oppression. Today, however, Icelanders are an independent nation governed according to the principles of a democratic republic.

According to the 1982 census, the population of Iceland was 229,187 , most of whom 1 ive in the coastal areas. The interior of the country is mostly mountains and deserts. While the country is rather poor in natural 
resources, the abundance of fish in the ocean surrounding the island provides the basis for the economy. The sea is the country's goldmine. The many rivers and the abundance of water provide the power for the production of all the electricity the country needs. Also, the seemingly limitless source of underground hot water has been tapped for various uses by most of the population, i.e., the heating of homes and greenhouses and for industrial purposes.

\section{First Settlers}

The island, windswept and almost destitute of trees, has a rugged beauty manifested in the stately mountains, the green valleys, the lakes, and waterfalls that, nevertheless, appeals to many. More than a millennium ago it attracted many of the Nordic Vikings who emigrated to Iceland from Norway, Sweden, and the Celtic countries. Ingolfur Arnarson is considered to have been the first permanent settler in Iceland. Arriving in A.D. 874, he settled in what is now Reykjavik, the capital city of Iceland.

There is, however, ample evidence of Christian hermits and monks from Ireland living in Iceland prior to the arrival of the Vikings. These individuals seem

${ }^{1}$ Knut Gjerset, History of Iceland (New York: The MacMillan Company, 1924), p. 12 . 
to have left hastily, perhaps because they did not desire to mingle with the heathen warriors.

\section{The Beliefs of the Vikings}

Most of the settlers were either heathen

worshippers or were believers in their own strength. One settler believed in both Christ and Thor. Helgi the Lean was a man of mixed faith; he seems to have believed in Christ except when it came to travels on the seas and other hard undertakings, then he set his trust on Thor. Although a few settlers were said to be Christians, like Audur djupudga (the deep-minded) ${ }^{3}$ and Ketill fiflski (the fool, thus nicknamed. when he became a Christian), the impact of Christianity at the time of settlement seems to have been minimal. The Sagas bluntly make the following statement about the first few Christian settlers and their influence: "But it was seldom adhered to by their descendants for the sons of them built temples and offered sacrifices and the country was wholly pagan for almost 120 years."

Place names in Iceland indicate the existence of temples (hof) during the period of settlement. These temples were, in most cases, dedicated to the worship of

${ }^{1}$ Islendingasogur, vol. 1 (Reykjavik, Iceland: Islendingasagnautgafan, 1946), pp. 1-2.

$$
\begin{array}{ll}
{ }^{2} \text { Ibid., p. 154. } & { }^{3} \text { Ibid., p. } 88 . \\
{ }^{4} \text { Ibid., p. 196. } & { }^{5} \text { Ibid., p. } 234 .
\end{array}
$$


Thor, the god of thunder, who among the Asar (the Scandinavian gods) was the most revered in Iceland at the time. Occasional references are made in the Sagas to human sacrifices in connection with Thor worship.

There is still to be seen the judgment ring where men were sentenced to sacrifice; in this circle stands Thor's stone, on which the backs of men used for sacrifice were ${ }_{1}$ broken; and the colour of the blood can still be seen.

Names of places and persons derived from Thor still abound.

As the Vikings continued their expeditions on the continent of Europe, they came into close contact with Christians. According to later developments, they seem to have begun to compare their own religion to that of the Christians. The Vikings were fearless, battle-hardened warriors who plundered, burned, and killed as they struck in hundreds of places throughout the continent. Confronted with the gentleness of Christianity and the saving Christ in contrast with their own cruel divinities, some were impressed. Gjerset writes:

As the Norsemen were fatalists believing that whatever happened was unavoidable, they did not feel inclined to wage any determined fight in behalf of their old deities. If Christ was destined to triumph, it was decreed by fate. Many already believed that the old gods were fighting a losing battle. There was a growing ${ }_{2}$ feeling that something new and better was coming.

${ }^{1}$ Islendingasogur, vol. 3 (Reykjavik, Iceland: Islendingasagnautgafan, 1946), p. 14 .

${ }^{2}$ Gjerset, p. 49. 
In the Book of Settlements, the following incident

is recorded about Thorkell Mani, the Law-Speaker

(Logsogumadur) in Iceland from 970 to 985:

In his last sickness he caused himself to be carried out into the sunshine, where he recommended himself to the god who had created the sun. But he also lived as pure a tife as any Christian who has the purest morals.

The Christianization of Icelanders

Towards the end of the tenth century, missionaries were sent to Iceland by Ring 01af Tryggvason of Norway who actively sought to convert people to Christianity, by force if necessary. Stefnir Thorgilsson came to Iceland in A.D. 996 but made little headway. He succeeded, however, in arousing the wrath of the Icelanders by pulling down some of their temples and burning images and gods. Banished from the island, he had to return to Norway. In 997 Thangbrandur, Ring 01af's chaplain, was dispatched to Iceland. He met with some success, although his methods were not always Christlike, as the following account describes so vividly:

\section{Islendingasogur, vol. $1, \mathrm{p} .33$.}

2 Thangbrand's missionary activities in Iceland are described in several accounts: Rristnisaga, Islendingabok, Laxdaelasaga. Also, according to Thorvald's Saga, written by Gunnlaugur Leifsson in the early 13th century, it was Thorvald Rodransson "the farfarer" who made the first attempt to preach the Christian gospel in Iceland. He arrived in Iceland about A.D. 981. However, after four years of mostly unsuccessful labor he had to leave the country. 
At Stafafell they met a man by the name of Thorkell who was so violently opposed to Christianity that he challenged Thangbrand to a duel. The doughty missionary advanced to the combat with a crucifix attached to his shield and slew his antagonist, a sort of missionary work quite in his style, nor was it the last time that he resorted to this sort of argument. At Arnartaksheidi his assistant Gudleif Arason slew another opponent, Galdra-hedin, and at Fljotshlid the poet Veturiidi, who ventured to compose lampoons about them, suffered the same fate. Torvald Veili, who gathered a band and planned to attack them, was also slain. But in spite of his violent methods, duals and homicides, Thangbrand was able to continue his labors from 997 till 999, and many leading chieftains were baptized.

The Icelandic Parliament, Althing, first called together at Thingvel1ir in A.D. 930 is, perhaps, the oldest parliament in the world. The chieftains met from all over Iceland to make provision for central government, to co-ordinate their laws and regulations, and to make judgments in disputes. This annual event lasted two weeks and quickly became the center of the national life.

The year 1000 marks a special milestone in the national experience. Althing decided that the Christian faith should henceforth be the religion of all Icelanders. Reminiscent of King Nebuchadnezzar's decree (Dan 3 and 6) 1500 years earlier which ordered all the Ring's subjects to worship the God of Daniel and his companions, so the Icelandic chieftains, a majority of whom were worshippers of Thor, decided to adopt the Christian religion. However, this did not come about without dramatic tension and a struggle.

$$
1_{\text {Gjerset, p. } 59 .}
$$


When Thangbrandur returned to Norway in 999 , he reported his missionary experience in Iceland in such negative terms to King 0laf, that the king became very angry and ordered that all non-Christian Icelanders who at the time happened to be at the seaport of Nidaros should be seized and executed. However,

Several influential Christian Icelanders, among them were Kjartan Olafsson, and also Gizur the White and Hjalti Skeggjason, who had just arrived from Iceland, pleaded with the king to show greater forebearance. They promised that all heathen Icelanders in Nidaros should receive baptism, and undertook to have Christianity fully established in Iceland. This wise counsel appeased the king. The heathen Icelanders were baptized, and Gizur and Hjalti remained at the king's court till the summer of the year 1000, when they 2 returned home to carry out their important mission. ${ }^{2}$

\section{Confrontation at Althing}

Thus the stage was set for a dramatic confrontation 3

at Althing between the forces of Christ and Thor, a1though the Christian chieftain-priests (godar) numbered only one-fourth of the total number of the chieftainpriests. With both sides at Althing we11 represented and ready for an armed fight, the situation was critical. Unless a compromise could be made, civil war was imminent. Then the leading godi (Law Speaker) among the Christians, Sidu-Ha1lur, made a clever decision. He suggested that

\footnotetext{
${ }^{1}$ Islendingasogur, vo1. 1, pp. 266-267.

${ }^{2}$ Gjerset, pp. 61-62.

${ }^{3}$ Althing was the term used for the annual outdoor law assembly. The Icelandic parliament has ever since
} retained this name. 
the leading godi among the worshipers of Thor, Thorgeir Ljovsvetningagodi, who also happened to be the Law-Speaker at this Althing, consider the Christian case. Whatever his judgment would be, it would be binding for all Icelanders. The question was: Should Icelanders become Christians or continue in their old tradition? Thorgeir accepted the challenge and eventually pronounced his judgment after a silent meditation under his robe on the subject for a whole night and a day. The two armies, spoiling for a fight, meanwhile waited anxiously for his decision.

As Thorgeir mounted the Law-rock, he addressed the Assemb1y: "Let us avoid extremes, and take the middle course; let us all have one law and one faith." ${ }^{1}$ The Assembly readily agreed and left the decision to him. He then made his pronouncement that all Icelanders should become Christians and be baptized at the first opportunity. However, the practice of heathen worship in secrecy was not to be punishable. The exposure of infants and the eating of horseflesh was to be permitted as before.

The Althing accepted Thorgeir's decision, civil war was averted, and the transition from one religion to another was peaceful. In fact, it seems that most of the

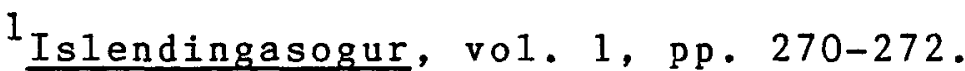


heathen were baptized on their homeward journey, or 1 immediately upon arriving home.

It can hardly be said that a genuine conversion was experienced by the people of Iceland under these circumstance. It was more a commonsense arrangement or a political settlement than a change of heart. With the armies of King $01 a f$ in Norway ready to pounce upon all heathen Icelanders who might resist Christian conversion, and with the king still holding several Icelandic chiefs hostage in Norway awaiting the outcome at Althing, the Icelanders really had no alternative.

\section{The Formative Period}

There is, however, more to the Christian experience than simply making a political decision. As far as the Icelanders were concerned, not much was accomplished among them to advance the cause of Christianity or Christian worship during the next dozen years or so after the momentous events at Althing. The task of making the new religion take permanent root in Iceland awaited another King 0laf who ascended to the throne in Norway in 1016 , and who later became known as 0laf the Saint.

He found in his own country that almost all the Christianity that his namesake had forced on it twenty years before had not unnaturally disappeared. Those that remained Christian were merely so in name. Much

\section{${ }^{1}$ Ibid.}

2 Heimskringla (Everyman's Library), pp. 117-396. (New York: E. P. Dutton and Company, n.d.). 
the same must have occurred in Iceland, which had few priests and places of worship, and apparently not any teachers. Nevertheless, the seed had been sown at last, though the ground was stony and many briars grew strong1y.

King 0laf, the Saint, set about changing the situation to a trend in favor of a vigorous Christianization of Iceland. He enlisted the help of the Law-Speaker of Althing, Skapti Thoroddsson, and it was he who saw to it that the recognition of pagan practices were dropped. From then on the Christian faith came into greater prominence in Iceland.

The next 250 years were definitely a formative period for the young nation, with the church (the Roman Catholic profession of faith) playing a critical role in the formation of the national culture. Although the Christianization of Iceland was largely accomplished through Norwegian influence, the Icelanders were free from foreign domination until 1262-64 when the commonwealth ended and Norwegian rule was accepted. Later, Denmark came to dominance over Norway in 1380, and Iceland also passed under Danish rule. Iceland remained under Danish rule until it finally declared its independence in 1944 .

\section{Plagues and Natural Disasters}

For several hundred years, the nation went through a series of disasters caused by frequent earthquakes and

${ }^{1}$ John C. F. Hood, Icelandic Church Saga (Westport, Conn.: Greenwood Press, Publishers, 1981), pp. 34-35. 
volcanic activities in different places. These led to famines and great losses in human life and livestock. Plagues also drastically reduced the population at times. In the fourteenth century there were at least eight disastrous earthquakes. The Great Plague ravaged the country during $1402-4$ and again in 1494. The volcanic eruptions of $1618-19,1625,1636$, and 1660 caused great destruction of land and property as well as a heavy loss of human 1ife. Major earthquakes occurred again in 1614, 1633, 1657, and 1661. Then during the years of 1579 and 1614-27, the nation suffered from a series of raids by English, Spanish, and Algerian pirates. According to a national census, the population of Iceland in 1703 was 50,444. This number was drastically reduced by the smallpox plague of 1707 in which 18,000 people died. Great volcanic eruptions and earthquakes destroyed many farms and cattle during the years from 1726 to 1757. This caused a famine in which thousands of people perished. In 1783, a devastating eruption destroyed 38 farms. The following year (1784), an even greater havoc was wrought by an earthquake that wrecked 133 farms and leveled 1,700 houses. More than 9,000 individuals died and loss in livestock was heavy.

1 This account is based on information gleaned from John C. F. Hood's list of highlights and events in the history of Iceland. See Hood, pp. 223-225. 
The struggle for survival as a nation, the. struggle against the natural elements, and isolation through the centuries has undoubtedly left its mark on the people of Iceland. They are a rather reserved people when it comes to expressing emotions and personal feelings, but they are outspoken and bold when they believe they have a just cause to defend or promote.

\section{Iceland Today}

Today, Iceland is a modern country whose people enjoy all the technological conveniences of our day. The standard of living has lately been among the highest in the world. Icelanders are enlightened people with 100 percent literacy rate. There are good communications throughout the country as well as with other countries. Major crimes are still rare in the country. It maintains a society where education is provided free on all levels, and socialized medicine provides virtually free medical service to its citizens.

\section{From Catholicism to Lutheranism}

Iceland may have switched from Thor worship to Roman Catholicism in the year 1000 by force, as already described, but the nation was to experience get another "conversion" before it was all over. Church historian John C. F. Hood briefly describes developments in Reformation Iceland: 
The years 1540-51 saw the passing of the Icelandic Church from the Roman obedience and its adoption of Lutheran reforms in religion, forcibly sponsored by the Danish administration. This political and ecclesiastical change took effect in the southern and northern dioceses in successive stages and was followed by a period of religious reconstruction latent in the earlier stages.

The Reformation in Iceland climaxed with the arrest and execution (by beheading) of the Roman Catholic bishop, Jon Arason, and his two sons in 1550. Although there certainly. were some signs of a genuine trend toward a true reformation in religious matters, the fact, nevertheless, remains that another confession of faith was again more or less forced upon the people of Iceland.

\section{Witchcraft and Superstition}

Another dark chapter in the national experience concerned the superstitious beliefs which eventually led to the so-called witchcraft burnings of about a score of individuals from 1625 to 1690.2 This imaginary crime was zealously prosecuted by some of the judges at the time. To this obsession with sorcery and the powers of darkness add the grim inheritance of pagan stories of ghosts, dangerous ogres, and beings who were believed to reside in rocks and hills (the hidden or unseen people = huldufolk).

$$
\begin{aligned}
& { }^{1} \text { Hood, p. } 142 \\
& { }^{2} \text { 0lafur Davidsson, Galdur og Galdramal a Islandi }
\end{aligned}
$$
(Reykjavik, Iceland: Solufelag, 1940-43), p. 80. See Magnus Shephensen, Island $i$ det 18de Aanhundrede (Copenhagen, Denmark: Den Gyldendahl Boghandlinge Forlag, 1808), pp. 165-185. See also Th. Thoroddsen, Landfraedisaga Islands, $2: 20 \mathrm{ff}$. 
During the long winter nights of the artic island, people occupied themselves with the kind of storytelling that chilled the most courageous souls and evoked fears of darkness and places identified with such beings.

The Supernatural and Spiritism

This background serves, perhaps, to explain the widespread interest among Icelanders in the occult, the supernatural, and the dead. According to a systematic random sample of the Icelandic population taken in 1974-75, 64 percent claimed to have had experience of the supernatural; 52 percent visited fortune tellers; 41 percent visited faith healers; 30 percent claimed to have felt the presence of a deceased person; 36 percent were convinced that they had dreamed about events that later occurred; and 56 percent claimed they had actually communicated with the dead. The survey showed that only 8 percent were regular readers of the Bible.

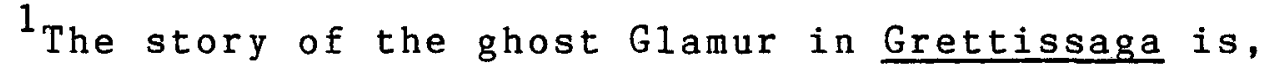
perhaps, the most famous. Other accounts of this nature abound in Icelandic literature and are widely read and referred to today. Other Sagas containing ghost stories are Egilssaga, Eyrbyggjasaga, Hardarsaga, Laxdaelasaga, and Njalssaga.

${ }^{2}$ Erlendur Haraldssom, "National survey of psychical experiences and attitudes towards the paranormal in Iceland," in Research in Parapsychology 1976, ed. J. D. Morris, W. G. Roll, and R. I. Morris (Metuchen, New Jersey: Scarecrow Press, 1977), pp. 182-186. This research was based on $M=902$, a response rate of $80 \%$. 
The high interest in the "afterlife" is further witnessed in the much-read obituaries that appear daily in the Icelandic newspapers. The obituary, written by one who knew the deceased well, is published in the local papers (frequent1y several obituaries appear about the same individual). Typically, an eulogy of the deceased is followed by an exposition of belief in personal immortality stating, for example, "He has now embarked upon a far journey to perform a higher work and greater

responsibilities." Frequently, the writer addresses the deceased as if he were present, alive, and fully conscious.

\section{The State Church}

In the Lutheran State Church also referred to as the National Church, people are of greatly variant persuasions. The Lutheran State Church encompasses comfortably the spiritualists, the fatalists, the rationalists, the unitarians, and the Lutheran fundamentalists, as well as those of the charismatic 1

nature. About 97 percent of the population belong to the Lutheran State Church, and about half of the remainder adhere to other Christian churches. The rest, perhaps 2,000-3,000 people, do not belong to any religious organization.

${ }^{1}$ Johannes Nordal and Valdimar Kristinsson, eds., Iceland 874-1974 (Reykjavik, Iceland: The Central Bank of Iceland, 1975), p. 32 . 
Few people attend church regularly in the Lutheran State Church. William H. Swatos, Jr., correctly refers to the occasional church attendance of Icelanders as 1 pilgrimages. While the churches are nearly empty most Sundays, they are usually full on special days, i.e., Easter, Christmas, and New Year's, or at funerals, weddings, and confirmations. Although Icelanders are hardly pluralistic in their religious interests, they are, however, tolerant of diverse religious views. Other Christian churches so far have not taken advantage of this religious tolerance to give the Lutheran State Church any serious competition.

The smaller denominations in Iceland, i.e., the Seventh-day Adventists, the Pentecostal Church, the Jehovah's Witnesses, the Roman Catholic Church (the most prominent minorities) and others, enjog complete freedom of worship and speech, as well as freedom to promulgate their doctrines. However, the Lutheran State Church has a virtual monopoly of the use of the government-operated radio and television services, for the broadcasting of church services. Seventh-day Adventists and the Pentecostal Church have had once-a-year access to the

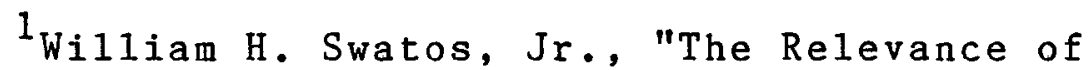
Religion: Iceland and Secularization Theory," in Journal for the Scientific Study of Religion 23 (March 1984): 32-38. Here Swatos has written a compact yet comprehensive article that has a bearing on church and religion in Iceland. 
radio for a nationwide broadcast of a church service.

These churches seldom have appeared on television. The state is responsible for the training of the ministers (prestar) for the Lutheran State Church. These ministers also receive their salaries from the government. Occasionally, they contend one with another over a pastorate that needs a new pastor; and sometimes a parish is so hotly contested that the congregation may split into factions, each supporting a favorite candidate. However, these feverish activities seem to indicate greater political or social fervor than religious interest. Nevertheless, interest in religion may be on the rise in Iceland. This is so if the increased enrollment of pre-ministeral students in the Theological Seminary at the University of Iceland is any indicator. In recent years the number of Seminary students has increased beyond the possibilities for pastoral appointments for all 1 graduates.

The Seventh-day Adventist Church in Iceland

The First Seventh-day Adventists in Iceland

The first Seventh-day Adventist known to have visited Iceland was 0 . J. Rost, a Norwegian minister, who

$$
{ }^{1} \text { Ibid., p. } 34 \text {. }
$$

"Iceland Conference," SDA Encyclopedia, 1976 ed. 10:614. See also J. C. Raft, "Iceland," in Review and Hera1d, February 11, 1915. 
sailed around the island in the summer of 1893. Stopping at various places he shared his faith with individuals and tested the prospects for future missionary activities. In the fishing town of Eskifjordur on the eastern coast', Rost was able to convince the Lutheran minister of his duty to keep the seventh day holy as the Biblical Sabbath. "Although this minister never became a member of the Seventh-day Adventist Church, he kept the Sabbath to the end of his days and in spite of opposition from his own church, retained his ministerial position."

\section{David Ostlund}

The pioneering work of establishing the Seventh-day Adventist church in Iceland was given to David Ostlund from Sweden, who, in November, 1897, was sent to Iceland by the Denmark Conference. ${ }^{2}$ A printer by trade and an energetic individual, Ostlund quickly set about publishing and distributing denominational literature in the vernacular.

In 1898 , within a year of his arrival in Iceland, Ostlund had published two books in Icelandic, The Second

\section{${ }^{1}$ Ibid.}

2Ibid. See also Bjorgvin Snorrason, "Pastor David Ostlund and the Beginning of the Seventh-day Adventist Church in Iceland" (M.A. thesis, Andrews University, The School of Graduate Studies, Berrien Springs, Michigan, 1975). Snorrason has done a thorough research on Ostlund's life and work in Iceland and has written a very interesting account of the beginning of the SDA work in Iceland. 
Coming of Christ, by James White, and Steps to Christ, by Ellen G. White. In 1900, having established his own printing press, he launched a new magazine, a semimonthly called "Fraekorn" (Seed), which for some time enjoyed the widest circulation of any paper in the country. Other publications were to follow in later years.

Nils Andreasen, a colporteur from Sweden, came to Iceland in 1903 and pioneered as a canvasser unti1 1916. The first Seventh-day Adventist Church was organized on May 19, 1906, in Reykjavik. A church building which was erected in 1905 was destroyed by fire in 1910, then rebuilt and dedicated in 1912 .

David Ostlund, a good student of the Icelandic language and culture, quickly adapted to the Icelandic way of life. This ability enhanced his work and effectiveness as a Seventh-day Adventist missionary in Iceland. Only five weeks after his arrival in the country, Ostlund preached his first sermon in the vernacular.

Ostlund's quick mastery of the Icelandic language was a great help to him as soon he was engaged in verbal duels with prominent theologians who opposed him "both by lectures and articles." ${ }^{4}$ The newspapers of the time gave Ostlund favorable reports as a public speaker.

David Ostlund the Norwegian Seventh-day Adventist who is now staying here and preaches every Sunday, most often at the Good-Templar's, is thought to be an
1 Ibid.
${ }^{2}$ Ibid
${ }^{3}$ Snorrason, p. 12
${ }^{4}$ Ibid., p. 18. 
excellent orator, hence multitudes throng to listen to him. Mr. Ostlund has learned Icelandic remarkably well in a very short time. He is a young man, well educated and a true gentleman. If his doctrine was not so unacceptable and peculiar as it is, then men of $\mathrm{Mr}$. Ostlund's chapacter would be very successful in soul-hunting.

Snorrason draws attention to the fact that in lectures and in articles 0stlund took on the onslaught of newly introduced schools of thought in Iceland--"the rational criticism of Scripture" and "the scientific hostility toward the Bible doctrine of creation." ${ }^{2}$ Foremost spokesman for these was Professor Jon Helgason of the Theological department of the University of Iceland. Later, Helgason became the Bishop of Iceland. It seems the critics met their match in David Ostlund.

\section{Crisis}

The Adventist Church grew slowly at first. However, by May 1909 , J. C. Raft was able to report to the General Conference that the SDA membership in Iceland stood at forty, besides the fifteen who were Sabbathkeepers but who had not as yet received baptism. Of the forty members, thirty-eight had been baptized during the last four years (1905-08). Just when the church was

\footnotetext{
1"Editorial," Thjodolfur, January 22, 1898, p.20. ${ }^{2}$ Snorrason, p. $18 \mathrm{ff}$.

${ }^{3}$ J. C. Rafts, "Iceland," General Conference
} Bulletin (May 1909), p. 127. 
becoming firmly established and the prospects for future growth were bright, adversity set in.

During all his years as an SDA missionary in

Iceland, Ostlund received only half salary from the SDA church. The Nordic Union expected him to make up the difference by selling Adventist literature. Whereas colporteur work did not appeal to Ostlund, he ventured into other lines of occupation such as insurance and real-estate for additional income. A series of financial losses eventually led 0stlund to embezzle funds entrusted to him, and he found himself a fugitive as he fled to the United States to avoid imprisonment.

\section{J. O1sen Replaces Ostlund}

When the Nordic Union settled his debt, Ostlund returned to Iceland. However, the Nordic Union decided to send another missionary to lead the church in Iceland. 0 . J. 01sen of Norway arrived in Iceland in August 1911. Ostlund, who had returned against the counsel of the Nordic Union, still considered himself the leader of the Seventh-day Adventist Church in Iceland. This caused the church to split into two parties, and for almost three

$$
\begin{aligned}
& { }^{1} \text { Snorrason, p. } 43 . \\
& { }^{2} \text { Ibid., p. } 44 . \\
& { }^{3} \text { Ibid., p. 50. See also Gudni Kristjansson, "Early }
\end{aligned}
$$
History and Development of the Seventh-day Adventist Church in Iceland" (M.A. thesis, Andrews University, The School of Graduate Studies, Berrien Springs, Michigan, 1977), p. 5 . 
years two rival SDA churches existed in Iceland. The branch which followed Ostlund was referred to as "The First Church of Seventh-day Adventists," the other as "The Nordic Union Church." ${ }^{1}$ According to Snorrason, Ostlund ceased to conduct Sabbath School, ceased to observe the Sabbath from sunset to sunset, and even rejected the church's teaching concerning the Spirit of Prophecy. In 1915 Ostlund left the country permanently and eventually his group dissolved.

As 0 . J. Olsen proceeded to take up the leadership of the SDA church in Iceland, he discovered that he had a determined competitor in 0stlund. Theg held separate 3 evangelistic meetings; they conducted a public "paper war" in the newspaper Visir; and they fought for official recognition by the ministry of church affairs. Eventually, 01sen emerged as the winner on all counts and became the undisputed and recognized leader of the SDA church in Iceland.

01sen soon mastered the language and launched enthusiastically into the evangelism which was to take him into many corners of the country. He baptized people and organized companies and churches in several places. The first group of believers to organize outside Reykjavik, the capital, lived in the town of Flateyri in the

$$
\begin{array}{ll}
{ }^{1} \text { Snorrason, pp. 50-64. } & { }^{2} \text { Ibid., p. } 66 . \\
{ }^{3} \text { Kristjansson, pp. } 18-19 . & { }^{4} \text { Ibid. }
\end{array}
$$


northwest. Nine individuals there united with the church and built a place of worship.

In 1915, 01sen baptized twenty-six individuals in Hafnarfjordur, a town 10 kilometers from the capital, and a congregation was organized there on April 17 of the same year. The work in this town seems to have been vigorous at first, as considerable interest was created in spite of opposition. Olsen took up residency here for one winter, and the congregation built its own house of worship, called Salem. However, by 1921 there was "no record of activity there, and Salem was in the process of being sold." ${ }^{3}$ There has been no SDA congregation in Hafnarfjordur for more than half a century.

\section{Petur Sigurdsson}

While interest in Hafnarfjordur was being cultivated by 01sen, a sma11 commuity on the southern coast at Eyrarbakki received the attention of another SDA evangelist, Petur Sigurdsson. In 1917, the baptism of nine individuals and the formation of a congregation of about eighteen believers at Eyrarbakki were reported. Sigurdsson spent no more than two years at Eyrarbakki,

${ }^{1}$ Braedrabandid, nos. $6-7,1972, \mathrm{p} .4$. This is the official paper, usualiy a monthly publication, of the Iceland Conference of Seventh-day Adventists.

${ }^{2}$ Kristiansson, p. 29.

${ }^{3}$ Ibid., pp. 42, 44. Salem was sold in 1922.

${ }^{4}$ Ibid., p. 32 . 
for in 1918 he was sent to break new ground in the northwest. Although a few Seventh-day Adventists remained at Eyrarbakki, they diminished in number through the years, and no Adventist congregation has been there for several decades.

From 1918 to 1920, Sigurdsson held evangelistic meetings in the northwest in the towns of Hnifsdalur, Isafjordur, and Bolungarvik. Large audiences attended in all three places, and congregations were organized. In 1919 twelve new believers were baptized in Isafjordur and Hnifsdalur. In 1921 Gudmundur Palsson, who labored in Sugandafjordur and Onundarfjordur, reported that "a few believers were located in Onundarfjordur who had been baptized in 1913." 2 In Bolungarvik a group of twenty-two believers was formed by Sigurdsson in 1920. Some of these individuals were baptized by 01sen the following year. 0lsen built a house for the use of the congregation in Bolungarvik. This house was known as Kirkjubaer (church house). During the vice-presidency of 0 . Frenning (1933-36), while Olsen was in Norway, this house of worship was sold. This sale was a great disappointment to Olsen who, upon his return to Iceland in 1936, saw opportunities for its use. For the past several

$$
\begin{aligned}
& { }^{1} \text { Ibid., p. } 36 . \\
& { }^{3} \text { Ibid., p. } 57 . \\
& { }^{4} \text { Braedrabandid no. } 6-7,1972, \text { p. } 4 .
\end{aligned}
$$


decades, no Adventist presence has been known in these towns of the northwest.

\section{Reykjavik Church Building}

In the early 1920s plans were laid and fundraising conducted for the construction of a church building in Reykjavik. This church was to be large enough to house al1 the meetings as well as mission offices and a health clinic. The task was completed in 1925.

\section{Vestmannaeyjar}

The next target for evangelism was Vestmannaeyjar off the southern coast of Iceland. There 01sen held meetings from late 1922 to 1923 with hundreds of people in attendance. In 1923 alone, fifty-eight individuals were baptized, and a church was organized on January 26, 1924 . Wherever 0lsen labored for any length of time, he erected buildings to accommodate the church activities. In Vestmannaeyjar he constructed the Badhusid in 1923 to serve as a residence for his family, as a meetingplace for the new congregation, and as a health clinic as well. This house, strategically located in the very center of town, was sold in 1951. However, in 1925 the church members themselves raised funds and constructed a church

$$
\begin{aligned}
& { }^{1} \text { Kristjansson, p. } 42 \\
& { }^{2} \text { Ibid., p. } 50 . \\
& { }^{3} \text { Ibid., pp. } 47,49 .
\end{aligned}
$$


1

building which has since served sufficiently as a meetingplace. Later, a school building was erected adjacent to the church.

Early in 1926 , or as soon as the new church building was completed in Reykjavik, 01sen began evangelistic meetings which were well attended. This effort resulted in 2 forty-six baptisms. In the fall of 1926 and the winter of 1927, Olsen held meetings in both new church buildings in Vestmannaeyjar and Reykjavik, and added another fortyfive individuals to the church membership.

\section{Olsen's Method of Outreach}

Gudni Rristjansson has written an interesting account of the life and work of 0 . J. 01sen in Iceland. He makes the following observation about 01sen's missionary strategy for Iceland: "In 1926 01sen developed a plan to spread the Advent message to all the major towns of the northern coast, move eastward, and slowly go around the entire coast of Iceland."

1 Braedrabandid, January 1976 , p. 16.

${ }^{2}$ Kristjansson, p. 56 .

3 Ibid., p. 58 .

${ }^{4}$ In addition to the above frequently referred-to report by Kristjansson, the reader is directed to another research report by same author, "Personal Aspects of 0laf J. Olsen's Missionary Life" (A term paper, Andrews University, School of Graduate Studies, Berrien Springs, Michigan, 1977). p. 57 .

${ }^{5}$ Kristjansson, "Early History and Development," 
Siglufjordur Church

Olsen began to implement his outreach to the rest of the country as he held meetings at the northern town of Siglufjordur during the winter of 1928-29. His labors were fruitful, and in 1929 he organized a church of fifteen members. During the summer he with Snorri Mikaelsson, a carpenter, and other church members built a for most of its history, and evangelistic outreach in later years was minimal. Church activities decreased steadily in the 1950 s as some church members moved to other parts of the country. In 1962 the church building, which had not been used for meetings for years, was sold. In 1970 the church organization at Siglufjordur was dissolved by conference constituency action.

\section{Akureyri Church}

From Siglufjordur, 01sen moved to Akureyri, the capital of the north, where he held meetings in the winter of 1929-30. Although 01sen considered this the most difficult town in Iceland to evangelize, he gathered a group of ten or twelve individuals to form a Sabbath

${ }^{1}$ Steinthor Thordarson, "The Seventh-day Adventist Church in Iceland Since 1928 " (M.A. thesis, Andrews University, The School of Graduate Studies, Berrien Springs, Michigan, 1973), pp. 34-35.

"Constituency Report," Braedrabandid, no. 5, 1970. 
School early in 1930. 1 Three years later (1933), after 01af Frenning labored there during the winter of 1932-33, a church was organized at Akureyri. In the summer of 1933, 01sen returned to Akureyri with Snorri Mikaelsson, 0laf Frenning, who the same year was elected as the conference vice-president, and Magnus Helgason, the conference treasurer, to build a church which was and still is in the center of this town of 14,000 people. Ear1y in the 1940 s church activities began to decline, and by 1947 the building was rented to one SDA family. Later, in 1953, the church building was sold. Today, it is owned and used by the town's band and a male choir.

\section{Skagastrond Church}

Another northern town, Skagastrond, also received the Advent message. Early in the 1940s Mrs. Anna Gisladottir, a resident of Skagastrond, came to Reykjavik to take lessons in sewing. Her instructor was a Seventhday Adventist lady. When Gisladottir returned home, she was a baptized Seventh-day Adventist, and she also won all the members of her household to her new-found faith. Later, other families and individuals in the area accepted the Adventist faith and joined the fellowship. A church was organized in 1952. Most of the time this church has

\footnotetext{
${ }^{1}$ Thordarson; pp. 26-27.

2 Ibid., p. 29.

3 Ibid., p. 37.
} 
been without a pastor. Presently, only a handful of elderly SDA church members remain at Skagastrond.

\section{Faskrudsfjordur Church}

Gudmundur Palsson, a licensed minister who entered mission work in 1914, came in 1931 to the small town of Faskrudsfjordur on the east coast. In 1942 a church was organized and members met in the home of the church elder. Through the years, the number of church members has steadily declined, mostly due to individuals moving to other towns. Presently, five elderly SDA members live at Faskrudsf jordur.

\section{Arnes Church}

By the gear 1945, several Seventh-day Adventists were scattered in various towns and the nearby countryside on the southern coast, beyond the mountains east of Reykjavik. 0. J. Olsen organized these individuals into church fellowship in 1945. However, during Johannes Jensen's tenure as conference president (1947-49), the congregation was dissolved.

1 Braedrabandid, no. 7-8, 1935, p. 34 .

2 Braedrabandid, no. 3, 1945.

${ }^{3}$ Sigfus Hallgrimsson, a pioneer educator and ordained minister, now retired. Private interview, Reykjavik, Iceland, in March 1973. 
The second organization of church members in this 1 area took place at Hlidardalsskoli in 1954. This reorganization of the local church was necessitated because the boarding school, which had been in operation for four years, with its faculty and staff members had increased the number of Adventists in the area. Arnes church now constitutes the second largest congregation in Iceland. A church center has been acquired in the town of Selfoss where services are held regularly. This church has normally received ministerial services from either the conference headquarters or the faculty of Hlidardalsskoli. More recent1y, however (in 1983), a young man has been appointed as the pastor of the Arnes church.

\section{Sudurnes Church}

The Sudurnes Church in the town of Keflavik in the southwest of Iceland was organized in 1947 with thirteen charter members. Gudmundur Palsson had labored in the area for seven years. Previously in 1916, 01sen had preached several times in the towns of Keflavik and Gardur. Over a twenty-year span, including the seven years prior to the organization of the church, the group met regularly in the home of 01 afur Ingimundarson, the church treasurer from the beginning (and still is at the time of this writing). In 1962 the group was too large to

\footnotetext{
${ }^{1}$ Braedrabandid, no. 4, 1954 .

2 Braedrabandid, no. 5, 1948 , p. 2 .
} 
be accommodated in the home, therefore, a hall was rented for all the church activities until they could be moved into the newly built church center in 1967 . $^{1}$ Accommodating three large halls, a children's Sabbath School room, young people's room, Dorcas rooms, offices, and a kitchen, the church was dedicated December 1970. Presently, the church membership is approximately forty.

\section{Church Schools}

The history of SDA church schools in Iceland is a rather sporadic one. David Ostlund opened a nine-grade church school in Reykjavik in 1905, with three we112

qualified teachers. This school, however, did not operate more than two or three years. Another school for the children of Reykjavik church opened in 1928 and, again, closed two years later. The next school opening in the Reykjavik church took place in $1942^{5}$ and lasted twentyfour years. A fourth attempt was made in 1976 when the Reykjavik church school opened once more and has remained until the present. Presently, the construction of a new

\footnotetext{
1 Braedrabandid, no. 1,1971, p. 2 .

${ }^{2}$ Snorrason, pp. 36-37.

${ }^{3}$ Julius Gudmundsson, president of Iceland
} Conference of Seventh-day Adventists from 1949 to 1968, to Steinthor Thordarson, July 1973.

${ }^{4}$ Hallgrimsson, interview, 1973.

5 Braedrabandid, no. 3, 1944, p. 12. 
school building is being planned. Land has been secured and financing of the project is well under way.

The Vestmannaeyjar Church opened its own school in 1928 which flourished for half a century. Due to decreasing numbers of school-age children in the church, it ceased operation in 1980 as a regular church school. Presently, the church uses the facilities as an activity center (skoladagheimili) where young school-age children can receive help for homework while their parents are still at work.

The Keflavik church opened a pre-school with fiftyfive children five to six years old in 1969. It became a popular venture as it met a felt need in the community. Attendance increased each year and in 1972 the town authorities approached the Adventists with an offer. The school would enroll all six-year-old children in the town of Keflavik (population 7,000). The town authorities would be responsible for all expenses involved in running. the school, including the teachers' salaries, supplies, and equipment, as well as rent for the facilities and the expense for utilities. The Adventists were to have complete freedom in running the school according to their

${ }^{1}$ Many school children in Iceland attend regular school either in the morning only or in the afternoon only, thus creating a problem for working parents. Skoladagheimili helps to meet this need. See Braedrabandid, September, 1983, p. 16. 
ideas, and all the teachers could be Seventh-day Adventists, if so desired.

The offer was accepted, a written agreement was signed by both parties, and four teachers were hired to perform the task of training the approximately 150 children. The arrangement continued for several years until the town authorities were able to accommodate this age group in their own enlarged school facilities. This experience indicates, perhaps, the goodwill and respect the Seventh-day Adventists enjoyed from the public. A regular church school begun in Keflavik in 1976, however, closed in 1983 due to lack of teachers.

Through the jears, but not continuously, an elementary church school has been operated on the premises of Hlidardalsskoli (a SDA boarding school on the secondary level) for the benefit of children of faculty and staff members of the secondary school. Sometimes children from nearby towns in the Arnes church district also attended. In 1976 to 1978 children living outside the school premises were brought daily to the school by a special bus. Presently, this church school is closed, but a few children from Arnes church commute to the church school in Regkjavik, a distance of about 50 kilometers.

\footnotetext{
$1_{\text {Thordarson, p. } 20 .}$
} 


\section{Secondary School}

Soon after World War II, plans were laid for the construction of Hlidardalsskoli, a co-educational boarding school on the secondary level at a site approximately 30 miles east of Reykjavik. The property of 30,000 acres is in the midst of an extensive area of mountain and lava fields and contains about 100 acres of tillable land. The constituency session of the Iceland Conference held in Reykjavik in 1947 decided to build the school. In the same action deciding the project, the purposes for the school were clearly stated. This action refers to the institution as "a mission school" to be established for the purpose of training poung people "to become missionary workers" in Iceland and abroad. The construction and operation of this institution was undertaken by a constituency that in 1950 numbered 324 (in 1983 the membership was 543 ).

1 "Since we are instructed by the Word of God and the Spirit of Prophecy that the young are to receive in our own schools the education they need for their daily life and to do the work of redeeming souls in other countries, it is resolved: that a mission school be established in Iceland on the land which the conference committee has bought this year; that the aim of the school be to educate the young to become missionary workers, and to give instruction which enables them to take up the various tasks of 1 ife and strengthens them against the many temptations of modern times, and also prepare them for "Gagnfraedaprof' (General Certificate of Education)." Iceland Conference of Seventh-day Adventists (Reykjavik, Iceland), Minutes of meetings of the Conference Committee, May 1947.

${ }^{2}$ General Conference of Seventh-day Adventists, Annua1 Statistical Report 1950 (a1so 1983). 
The school, which opened in 1950 with nineteen 1

students, was established to meet the educational and spiritual needs of SDA youth in Iceland. In most years, grades 7 through 10 were available to students in attendance.

Among the more than one thousand students who have attended Hlidardalsskoli are many individuals who have taken up positions of leadership in the SDA church and in society. Several students, some of whom were not Adventists when they first enrolled in the school, have become teachers and ministers in the SDA church. While non-Adventist students were not to be excluded from admission, it was not expected that they should ever outnumber Adventist students. Within a few years, however, there were more applications for admission than the school could accommodate. A new dormitory was built in 1959 , which made it possible to double the enroliment. Subsequently, as many as eighty or more students were in attendance each year. From 1977, students were also admitted for grade 11 , and from 1978 for grade 12. Due to decreasing enrollment these two grades were discontinued in 1982 .

As the number of prospective Adventist students of the appropriate age to attend Hlidardalsskoli each year was insufficient to fill the school, the increased $10: 588$.

I"Iceland Conference," SDA Encyclopedia, 1976 ed., 
enrollment was made up of non-Adventist students. Through the years this has caused much discussion in Adventist circles, and many have voiced their displeasure over the admission of so many non-Adventists students.

The average student ratio during the thirty-two years of operation from 1950-1982 was roughly 25 percent Adventists to 75 percent non-Adventists (see table 5 in appendix $C$ ). For twenty-five of the thirty-two years Adventist students were in the minority.

SDA parents and church leaders viewed this student ratio as detrimental to the spiritual life among the students. Writing in Braedrabandid in 1976, conference president Sigurdur Bjarnason summarized these concerns and outlined the steps being taken to remedy the situation.

There has always been a considerable number of non-Adventist students at Hlidardalsskoli. As the gap between the church's standard on one side and the standard of the world on the other side has constantly widened, the presence of such students has increasingly become a problem for the school. In later years Adventist students have been rather few. We realize that Christian education means salvation for our children and youth. We have asked ourselves if the presence of many non-Adventist students in the school and their influence on the school-life worked against this goal.

Shortly before the recent conference constituency meeting the Education Director of the General Conference, Dr. W. J. Brown, and the Education Director of the Northern Europe-West Africa Division, Hugh I. Dunton, came to this country as requested by the conference committee. They attended meetings of the Hlidardalsskoli board and the conference committee where matters of interest to Hlidardalsskoli were discussed.

After a careful consideration it was decided to reduce, step by step, the number of non-Adventist students so that henceforth their number should never be more than 
10 percent of the total number of students, and Adventist ${ }_{1}$ youth could thus always form a decisive majority.

Furthermore, in his report to the 1976 constituency meeting, President Bjarnason spoke of the new plan to have Hlidardalsskoli concentrate its services upon the youth of the church.

Plans have now been laid to make the school (Hlidardalsskoli) a church school, that is to say, that it will first of all serve the children of the church, and the aim is that non-Adventist students will not be more than 10 percent of the total number of students.

The unfavorable ratio of the SDA students to non-Adventist students has been the topic of discussion at several constituency meetings in Iceland. In his threeyear report to the constituency session in Reykjavik, Apri1 7-11, 1982, president Snorrason made the following comments:

On the other hand, the experience of past years has brought to light how difficult it is to create financial basis for such a small school and also maintain a favorable ratio between youth. from Adventist homes and youth from other homes.

There has also been brought forth a very stern warning about the unfortunate influence from the undesirable ratios between those who come from Christian homes and the others who have almost no knowledge of Christianity or an upbringing under Christian influences.

Furthermore, the faculty of Hlidardalsskoli has become increasingly concerned about the adverse effect

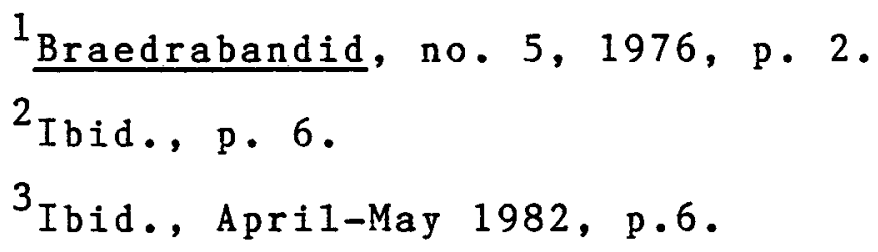


this unfavorable student ratio has had on Adventist students (see appendix $B$ on a letter to the school board from the faculty).

The expressed concern about student ratio coupled with decreased student enrollment in boarding schools in Iceland due to increased school facilities in town led to the reduction in the student body of Hlidardalsskoli. In the autumn of 1984 , the total enrollment was twenty-nine students, seven of whom were from an Adventist background. of the twenty-nine, six were former students. Presently, only grades 8 and 9 are being maintained.

Diminishing enrollment at the school has led to a reduction in operating funds. Regular subsidies and appropriations from the Northern Europe Division have enabled the conference leaders to keep the school going. In addition, the government has given a grant to the school each year. In 1981 this grant was Ikr. 84,000, or the equivalent of one salary. This was increased in 1982 to Ikr. 204,522, which at the time equaled 1.9 salaries. Donations from church members in 1981 were Ikr.

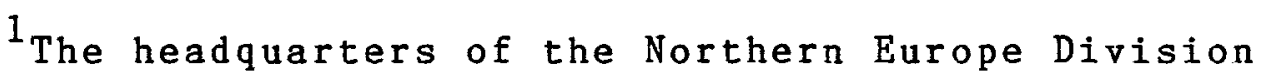
of the Seventh-day Adventist Church is in St. Albans, England.

2 Braedrabandid, no. 3, 1981 , p. 9; no. 6, 1981 , pp. 12-13; March 1982, p. 11 .

${ }^{3}$ A11 computations for salaries in this section are based on what constituted a 100-percent salary. Due to the unstable economy in Iceland caused by high inflation 
95,535, the equivalent of 1.4 salaries, and in $1982 \mathrm{Ikr}$. 138,689 , the equivalent of 1.3 salaries.

In 1981 the net operating loss without subsidies was Ikr. 818,124 (after government grant but before members' donations have been entered as income). This equaled 11.6 salaries.

In 1982 the net operating loss without subsidies was Ikr. 548,329 (government grant has been entered as income but not donations from members). This would represent five salaries.

The school's financial statements show that the combined net operating loss for the two fiscal years (1980-81 and 1981-82) exceeded the total salaries and related expenses paid to the staff and faculty for the same period. In comparison, the total salaries paid in

and frequent devaluations of the Icelandic krona, I have chosen to represent financial figures in terms of 100-percent salaries, as they are in any given period in the Iceland Conference of the Seventh-day Adventist Church.

${ }^{1}$ A11 figures are based on the Financial Statements for Iceland Conference and Hlidardalsskoli for the years of 1981 and 1982 .

2 During the 1980-1981 school year there was an emergency repair made on the heating plant at the cost of Ikr. 222,855. The Northern European Division provided a special appropriation of Ikr. 103,208 to help meet this unexpected expense. Deducting the balance of the emergency repair expense from the net operating loss for the year would still leave a loss equal to 9.9 salaries.

${ }^{3}$ Salaries were greatly increased in 1982. Ikr. 109,199 represented a 100 percent salary during fiscal year 1981-82. 
1982 to all ful1-time and part-time workers in the conference (not including staff and faculty of Hlidardalsskoli) was Ikr. 877,288. Translated into salaries, this amount covered 6.8 fulltime workers each on 100 percent salary.

\section{Conference Administration}

As mentioned above, 0 . J. O1sen became the leader of the Iceland Mission in 1911. In 1930, Iceland Mission and the Faeroe Islands Mission were combined as one field and organized as the Iceland -Faeroe Island Conference. At this time 0 . J. Olsen became the conference president for the enlarged field, in which capacity he served until 1947.

The Faeroe Islands were separated from Iceland in 1947. After this organizational change, the field has always been referred to as the Iceland Conference of Seventh-day Adventists. Organizational1y, the Iceland Conference is an attached field with direct access to the administration of the Northern Europe Division of the SDA Church, St. Albans, England. The conference president usually attends the spring and autumn meetings of the Northern Europe Division.

It has been pointed out that when 0 . J. O1sen had effectively taken over the leadership of the Iceland Mission from David Ostlund, he occupied himself mainly with outreach endeavors by holding evangelistic meetings 
in many towns around the country. He continued this work vigorously for about two decades with the assistance of energetic helpers such as Petur Sigurdsson, Niels Andreasen, and Gudmundur Palsson. These assistants usually did the preparatory work of visiting people, giving Bible studies to interested individuals distributing literature, and even holding evangelistic meetings.

After the groundwork had been laid by these individuals, 0lsen would arrive to baptize those who were ready to join the church. This was frequently followed by the organization of a church. This proved to be a wise strategy as it steadily added to the membership of the new, fledgling church. It also provided the members of the church with a new and worthwhile cause with which to occupy themselves after the tumultuous years of transition of leadership from Ostlund to Olsen. The preparatory work for the churches in Hafnarfjordur and Vestmannaeyjar was done by 01sen himself.

The list of churches and companies shown in table 1 reveals to what extent the SDA church spread in Iceland in the first part of the century.

Of the fourteen churches and companies listed seven had a church building or a house of worship constructed by 01sen. However, a few years after the groups were organized, some of them began to decline and eventually were dissolved organizational1y. These 
churches included those at Flateyri, Bolungarvik, Hnifsdalur, Isafjordur, Akureyri, Siglufjordur, Eyrarbakki, and Hafnarfjordur. Perhaps this is due to lack of necessary follow-up and nurture. Ministerial workers usually stayed only a brief time in each place before going on to other assignments.

Another possible explanation for the disintegration of the churches along the coastline could be the church leaders' pre-occupation with Christian education, for these absorbed the energies and resources of the church. The successful operation of Vestmannaeyjar church school (opened in 1928) and of Reykjavik church school (re-opened in 1946) increasingly occupied church leaders with matters of Christian education. Evidently, the gradual switch in emphasis in church activities from public evangelism towards schools and Christian education was made at the expense of church growth.

0. J. 01sen led out in the SDA Church in Iceland for thirty-six years. During all those years one finds no record of a national being ordained to the gospel ministry during 01sen's tenure. The first national to be ordained was Julius Gudmundsson who was ordained in 1949, two years after 01 sen left the helm.

Furthermore, there is no record in conference committee actions or the church papers of individuals being set aside for training for future leadership positions. When 01sen left (in 1947), leadership was 
TABLE 1

FORMER AND PRESENT SDA CHURCHES IN ICELAND

\begin{tabular}{|c|c|c|c|c|}
\hline Town & $\begin{array}{c}\text { Church } \\
\text { Organized }\end{array}$ & $\begin{array}{c}\text { House } \\
\text { of } \\
\text { Worship } \\
\end{array}$ & $\begin{array}{c}\text { Building } \\
\text { Sold }\end{array}$ & $\begin{array}{c}\text { Present } \\
\text { Situation } \\
\end{array}$ \\
\hline Reykjavik & 1906 & Yes & & $\begin{array}{c}\text { Organized } \\
\text { church }\end{array}$ \\
\hline Flateyri & 1913 & Yes & Yes & No church \\
\hline Hafnarfjordur & 1915 & Yes & Yes & No church \\
\hline Eyrarbakki & 1917 & No & & No church \\
\hline Hnifsdalur & 1919 & No & & No church \\
\hline Isaf jordur & 1919 & No & & No church \\
\hline Bolungarvik & 1920 & Yes & Yes & No church \\
\hline Vestmannaey jar & 1924 & Yes & & $\begin{array}{l}\text { Organized } \\
\text { church }\end{array}$ \\
\hline Siglufjordur & 1929 & Yes & Yes & No church \\
\hline Akureyri & 1933 & Yes & Yes & Company \\
\hline Faskrudsf jordur & 1942 & No & & Company \\
\hline Arnes ${ }^{1}$ & 1945 & Yes & & $\begin{array}{l}\text { Organized } \\
\text { church }\end{array}$ \\
\hline Sudurnes ${ }^{2}$ & 1947 & Yes & & $\begin{array}{l}\text { Organized } \\
\text { church }\end{array}$ \\
\hline Skagastrond & 1952 & No & & Company \\
\hline
\end{tabular}

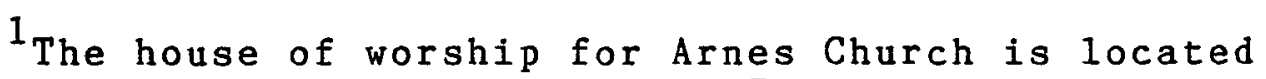
in the town of Selfoss, in southern Iceland.

2 The Sudurnes Church is located in the town of Reflavik, in the southwest. 
given to another foreigner, Johannes Jensen from Denmark. During the last two decades the conference has given financial support towards the training of several workers, and seven individuals have been ordained to the gospel ministry •

From 1947 to 1949, Johannes Jensen was the president of Iceland Conference. The first Icelander to serve in this capacity was Julius Gudmundsson, from 1949 to 1968 , or 19 years. A Norwegian, Svein B. Johansen, was president from 1968 to 1973; and another Icelander, Sigurdur Bjarnason, served as president from 1973 to 1980. The present conference president is Erling B. Snorrason who assumed the leadership in 1980 .

The history of the SDA conference in Iceland reveals that a vigorous work of evangelism, especially during the second and third decade, led to the organization of several churches and companies. Later, eight congregations were dissolved, and houses of worship in five places were sold. This deterioration in Adventist presence around the country probably can be attributed to a lack of spiritual nurture and follow-up ministry for these congregations.

Growth Figures

From 1906 to 1927 a new church was organized on the average of one every 2.6 years; from 1928 to 1950 there was an average of 4.6 years between the organization of 
new churches. However, since 1950, only one new church has been organized, the Skagastrond church, in 1952 . Since then, or for thirty-two years, no new church has been organized in the Iceland Conference (see figure 1).

Church membership figures for the thirty-four years from 1950-1984 show that on the average 6.4 individuals were added to the church annually (a total of 219). This figure does not adequately reflect missing and apostatized members. The membership records of the conference contain dozens of names of individuals who no longer attend the Seventh-day Adventist church or adhere to its principles.

At a meeting in the Iceland Conference in October 1983 (which I attended in preparation for the survey), the ministers, all of whom attended, agreed that hardly more than 200 of the church members 1 isted attend church regularly. This means that less than half the number of baptized Seventh-day Adventists presently attend church regularly. (Note SDA membership graph in figure 2.)

Although the official membership in the Iceland Conference in 1982 was $546^{2}$ (notice reduction from

${ }^{1}$ Conference President ErIing B. Snorrason reported to the constituency session of the SDA Church in March 1982 that "The number of church members at this time is, according to church records, 549 (1981 figure). We are very much aware of the fact, which hurts and saddens, that a large group included in this figure is made up of inactive members. . . " Braedrabandid, March 1982 , p. 6 .

2 This is according to the Statistical Report of the General Conference of the Seventh-day Adventist Church for 1982 . 


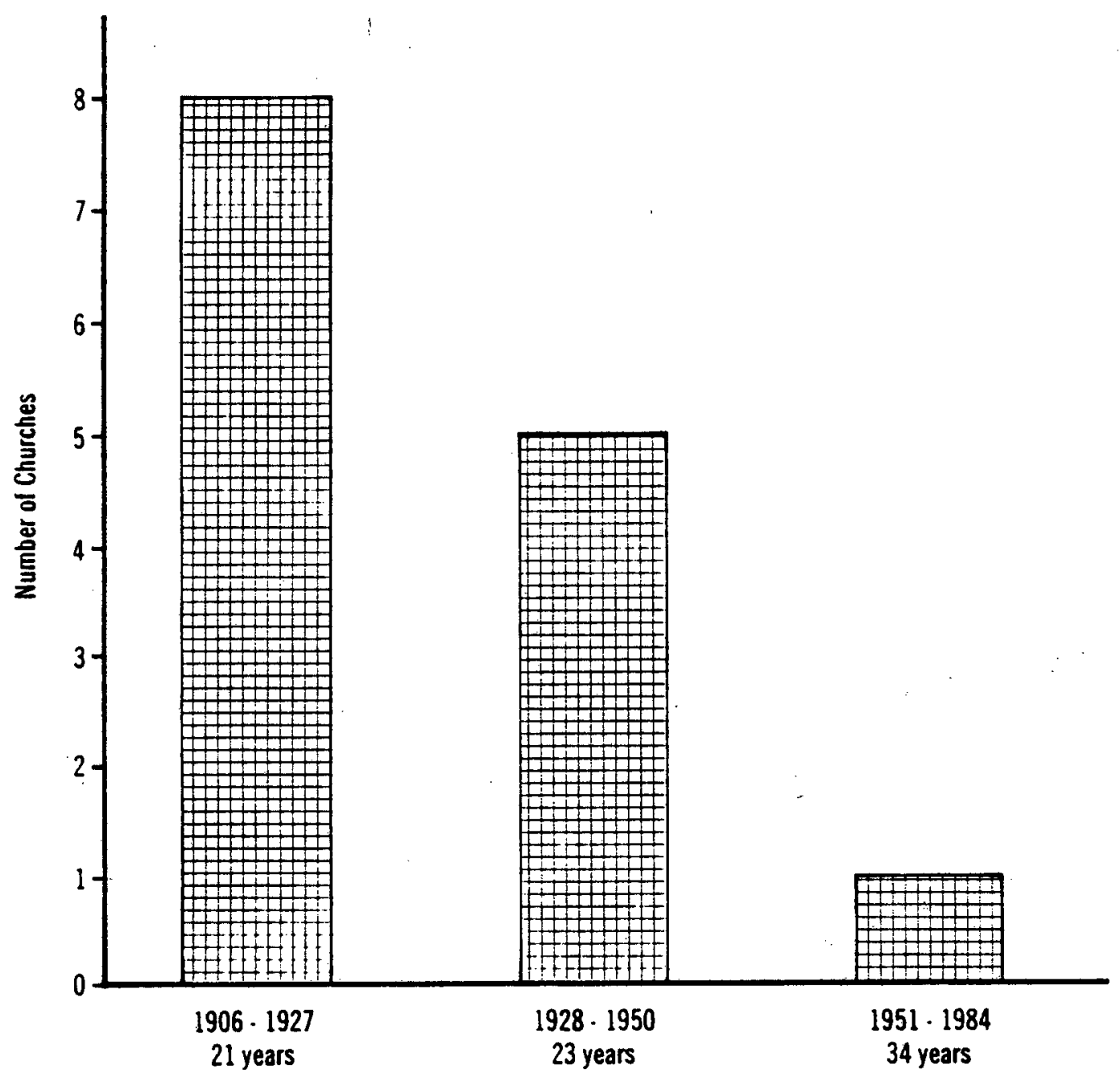

Fig. 1. Number of churches prganized during each of
three time periods. previous year), the number of delegates authorized (a total of 35) to represent the local churches at the 1982 constituency meeting indicates that the number of active

${ }^{1}$ In 1928 the shift to a school approach church growth began with the opening of two church schools. Late in 1950 the secondary school, Hiidardalsskoli, began as we11. 
church members in Iceland is closer to $300^{1}$ (see table 2).

A better way to visualize the growth and decline of SDA church membership in Iceland is to note the line graph in figure 2 .

The Icelandic Bureau of Statistics publishes annually the membership figures for the various denominations in Iceland (see table 3). According to the 1983 report, the SDA Church is the fourth largest denomination in Iceland. Formerly, when Adventists pursued a vigorous

TABLE 2

ICELAND CONFERENCE MEMBERSHIP 1950-1983

\begin{tabular}{|c|c|c|c|c|}
\hline $\begin{array}{ll}\text { Yr. } & \text { No. } \\
1950 & -324\end{array}$ & $\begin{array}{lr}\text { Yr. } & \text { No. } \\
1957 & 366\end{array}$ & $\begin{array}{lr}\text { Yr. } & \text { No. } \\
1964-453\end{array}$ & $\begin{array}{l}\text { Yr. } \\
1971-492\end{array}$ & $\begin{array}{lr}\text { Yr. } & \text { No. } \\
1978-537\end{array}$ \\
\hline $1951-360$ & $1958-374$ & $1965-454$ & $1972-501$ & $1979-540$ \\
\hline $1952-366$ & $1959-403$ & $1966-455$ & $1973-505$ & $1980-541$ \\
\hline $1953-364$ & $1960-416$ & $1967-456$ & $1974-498$ & $1981-549$ \\
\hline $1954-367$ & $1961-431$ & $1968-461$ & $1975-498$ & $1982-546$ \\
\hline $1955-376$ & $1962-436$ & $1969-466$ & $1976-508$ & $1983-543$ \\
\hline $1956-367$ & $1963-444$ & $1970-476$ & $1977-526$ & \\
\hline
\end{tabular}

SOURCE: General Conference of Seventh-day Adventists, Statistical Reports. (Washington, D.C.: Review and Herald Publishing Association, 1950-1983).

${ }^{1}$ In the absence of reliable membership figures for individual churches, I have resorted to approximating the figures by looking at the number of delegates each church was authorized to send to the 1982 constituency session. 


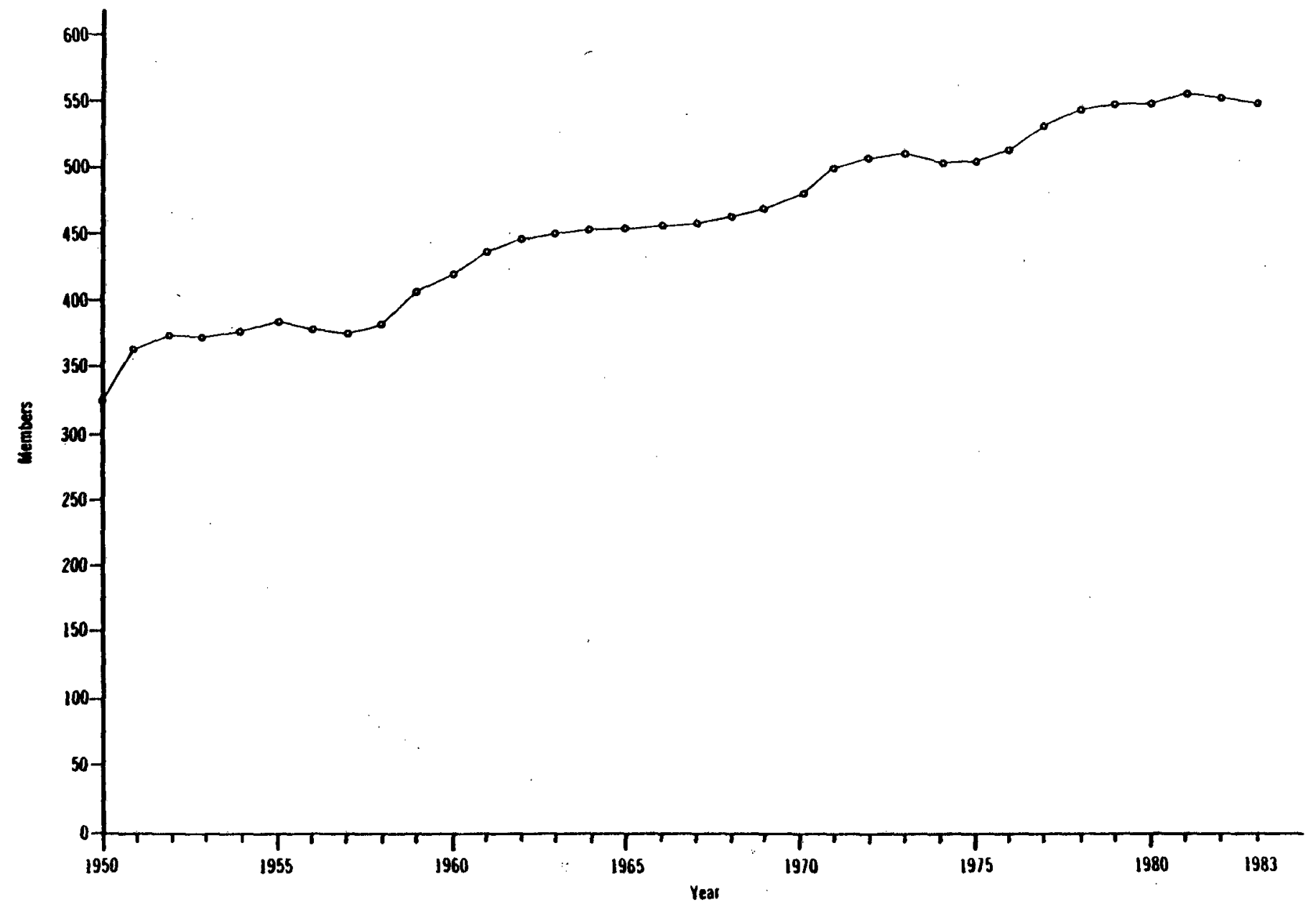

Fig. 2. Graph lines indicating rise and fall of Icelandic S.D.A. membership. 
TABLE 3

MEMBERSHIP NUMBERS IN DENOMINATIONS IN ICEL_AND

(Numbers given for years since 1860 as indicated)

\begin{tabular}{|c|c|c|c|c|c|c|c|c|c|c|c|c|c|c|c|c|}
\hline Denomination & 1860 & 1901 & 1930 & 1960 & 1964 & 1973 & 1974 & 1975 & 1976 & 1977 & 1978 & 1979 & 1980 & 1981 & 1982 & 1983 \\
\hline $\begin{array}{l}\text { Lutheran } \\
\text { State Church } 6\end{array}$ & 66985 & 78311 & 107369 & 171632 & 185878 & 207594 & 210795 & & 214514 & 215900 & 217428 & 219530 & 221847 & 224457 & 227756 & 230504 \\
\hline Cathollc Church & 2 & 27 & 191 & 897 & 1008 & . 1309 & 1361 & & 1433 & 1487 & 1543 & 1571 & 1614 & 1661 & 1696 & 1633 \\
\hline S.D. Adventists & $\mathbf{s}$ & 6 & 421 & 533 & 551 & 635 & 639 & & 646 & 664 & 665 & 665 & 659 & 666 & 675 & 681 \\
\hline Pentecostal Ch. & 0 & 0 & 7 & 530 & 550 & 613 & 627 & & 638 & 652 & 650 & 660 & 691 & 704 & 734 & 722 \\
\hline $\begin{array}{l}\text { P1ymouth } \\
\text { Brethren }\end{array}$ & 0 & 0 & 68 & 75 & & 59 & 60 & & 60 & 56 & 57 & 59 & 56 & 54 & 51 & 50 \\
\hline Jehovah's Witn. & 0 & 0 & 0 & 56 & & 251 & 269 & & 301 & 290 & 297 & 306 & 319 & 328 & 332 & 343 \\
\hline Bahai & 0 & 0 & 0 & 0 & 0 & 59 & 71 & & 112 & 135 & 174 & 216 & 227 & 243 & 269 & 286 \\
\hline Asa Fafth ${ }^{2}$ & 0 & 0 & 0 & 0 & 0 & 58 & 70 & & 77 & 68 & 72 & 68 & 67 & 68 & 69 & 68 \\
\hline $\begin{array}{l}\text { Others \& } \\
\text { Unspecif. }\end{array}$ & 0 & 51 & 24 & 37 & 239 & 204 & 255 & & 227 & 230 & 388 & 554 & 578 & 622 & 553 & 661 \\
\hline $\begin{array}{l}\text { Outside Re. } \\
\text { Comm. }\end{array}$ & 0 & 61 & 781 & 1920 & 2004 & 2288 & 2395 & & 2537 & 2573 & 2643 & 2710 & 2727 & 2805 & 2845 & 2946 \\
\hline
\end{tabular}

Source: Hagtidindi, Reykjavik, Iceland: Hagstofa Islands. This is the annual statistical report published by the Bureau of Statistics. These figures include children who are considered to be of the same faith as their mother. Such a reckoning 1s 11kely to 1nflate the real membership figures (see table 2 for SDA figures).

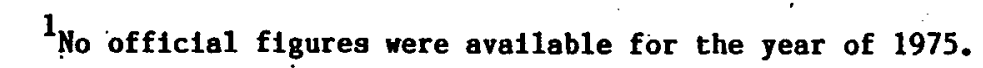

This group consists of Individuals who seek to revive and promote the worship of the gods, asar, of the vikings of old. 
sense. Their emphasis is on personal visitations and, in the case of Bahai, fellowship groups and personal discussions have priority over everything else. The Pentecostal Church has no schools but operates an institution for alcoholics. The Jehovah's Witnesses and Bahai maintain no institutions.

\section{Evangelistic Campaigns}

Evangelistic meetings have been conducted regularly through the years by national ministers. These are

TABLE 4

COMPARISONS OF CHURCH GROWTH IN DENOMINATIONS IN ICELAND

\begin{tabular}{lccc}
\hline \hline \multirow{2}{*}{ Denominations } & \multicolumn{3}{c}{ Percentage of Increase } \\
\cline { 2 - 4 } & $1964-1973$ & $1974-1983$ & 1ast 10 \\
\hline Lutheran State Church & 12 & 11 & 1.1 \\
Catholic Church & 30 & 21 & 2.1 \\
S.D. Adventists & 15 & 7 & .7 \\
Pentecostal Church & 11 & 18 & 1.8 \\
Plymouth Brethren & $*$ & -15 & \\
Jehovah's Witnesses & $*$ & 37 & 3.7 \\
Bahai & $*$ & 385 & 38.5 \\
Asa Faith & $*$ & 17 & 1.7 \\
Others \& Unspecified & -15 & 224 & 22.4 \\
Outside Rel. Communities & 14 & 29 & 2.9 \\
\hline
\end{tabular}

Source: Hagtidindi, Reykjavik, Iceland: Hagstofa Islands.

* Missing figures were either non-existent or unavilable. 
usually held during the fall and winter seasons when people are more accessable than at other seasons. Generally speaking, Lutherans in Iceland do not easily change their profession of faith. Yet, some non-Lutheran denominations enjoy a higher growth rate than others (see table 4). Most additions to membership in the nonLutheran churches come from the Lutheran State Church.

In an attempt to boost the rate of growth in the Adventist church, conference leaders for three decades consistently have called on foreign evangelists to conduct evangelistic campaigns in Iceland. Most of these have been held in the capital city. Guest speakers usually stay for two or three months each time. Visiting evangelists since 1948 have been the following: 1948 - Axel Varmer of Denmark began public meetings which were continued by Johannes Jensen, also a Dane, who at the time was the conference president.

1953 - The conference executive committee of the Icelandic Conference requested the Northern European Division to send "a really good preacher" to come to Iceland to conduct public evangelistic meetings.

1955 - Lamont Murdoch, a British minister, was sent in response to above request. He held meetings in a

I Braedrabandid, no. 4, 1949, p. 2 .

${ }^{2}$ Iceland Conference of Seventh-day Adventists (Reykjavik, Iceland), Minutes of Meetings of the Iceland Conference Committee, September 28, 1953 and December 22, 1953 . 
large cinema, Stjornubio, in Reykjavik.

Disappointment was expressed over the meager 1

results.

1958 - O. J. 01sen, an Icelandic-speaking Norwegian and a 59 pioneer worker in Iceland, returned from retirement abroad to hold meetings in Reykjavik. ${ }^{2}$

1963 - 0. J. 01sen returned again to conduct autumn 64 meetings in Reykjavik and Keflavik. Then he held winter meetings in Vestmannaeyjar.

1965 - 0. J. Olsen çonducted winter meetings in Reykjavik. "Only a few ready to follow the message immediately."

1970 - Eric Erenius from Sweden planned a series of meetings in Reykjavik. However, he became seriously ill before the meetings began and had to cancel them.

The conference constituency in session in 1970 voted "to endeavor to secure an evangelist from

${ }^{1}$ Braedrabandid, no. $1,1956, \mathrm{p} .3$; and no. 10,1956 , p. 4

${ }^{2}$ Iceland Conference of Seventh-day Adventists (Iceland, Reykjavik), Minutes of Meetings of the Iceland Conference Committee, May 29, 1959 and March 31, 1959.

3 Braedrabandid, no. 11-12, 1963, p.2; and no. $11-12,1963$, p. 1 .

${ }^{4}$ Braedrabandid, no. $6-7,1965$, p. 3 .

${ }^{5}$ Ibid., no. 11,1969, p. 5. 
overseas to do outreach work in this country by conducting public meetings, as soon as possible."

1972 - Fall meetings were held in Reykjavik and Keflavik by Kenneth Wright from Australia. His lectures were characterized by an emphasis on archeology. The largest meeting halls in both places were secured. Attendance in Reykjavik the first night was 2200 , and in Keflavik 220. Three baptisms are credited to these meetings.

1980 - David Lawson, also sent by the Northern European Division, conducted evangelistic meetings in Frikirkjan in Reykjavik in February and March. Four individuals were baptized.

1981 - Don Lowe of Northern European Division and Martin Bell of the British Union of the SDA Church visited Vestmannaeyjar for one week in preparation for a planned campaign a year later.

1982 - Don Lowe conducted meetings in Vestmannaeyjar. Bengt Lillas, a Swedish-speaking Finn, held meetings at Selfoss in February.

\footnotetext{
I Ibid., no. 7, 1970, p. 19.

${ }^{2}$ Ibid., no. 8-10, 1972 , p. 2 .

${ }^{3}$ Ibid., no. 12, 1979, p. 13; and no. 3-4, 1980, p. 16.

${ }^{4}$ Ibid., no. 6,1981, p. 15 .

${ }^{5}$ Ibid., no. 1,1982, p. 15.

${ }^{6}$ Ibid.
} 
Dr. John Berglund, the Northern European Division

Health Director, conducted meetings in Reykjavik in September and October.

1985 - David Lawson conducted another series of public evangelistic meetings in Reykjavik in February and March. This time the meetings were held in the Icelandic Opera House (Gamla Bio).

Church records provide scant information about the contribution of these guest evangelists to numerical increase in membership. One is left with the impression that the series of evangelistic meetings listed above have not, in spite of financial expenditure, accomplished much in terms of church growth. Public evangelism and its contribution to church growth in Iceland is be considered further under "Public meetings," pp. 133-134.

\section{Other Forms of Outreach}

The Seventh-day Adventist Church in Iceland has in past decades introduced several other kinds of outreach ministries.

\section{Publishing Work}

Literature evangelism has a long history in SDA Church in Iceland. The first book, Steps to Christ, by E. G. White, was published in the vernacular in 1898 by David 0stlund. More books in the vernacular followed later and

$$
{ }^{1} \text { Ibid., p. } 14 \text {. }
$$


through the decades colporteurs have diligently distributed these throughout the country. Some were message books, other's were children's books, i.e., Bedtime Stories. Most book titles published during the first half of the century are now out of print.

In the early 1960 s the four-volume set, Footprints of Jesus, by W. L. Emmerson, printed in color, proved to be a successful item for house-to-house sales. Next followed the ten-volume set Bible Story, by A. S. Maxwell. These volumes were printed one by one for more than a decade, or from 1968. A major single-volume publication is The Great Controversy, by E. G. White, published in 1976 .

A two-volume abridged edition of Testimonies for the Church, by E. G. White, was published in 1976-78. Other titles by the same author published in the vernacular are My Life Today (1980), Marantha (1984), and Counsels on Stewardship (1984). The latest book authored by E. G. White, to be translated into Icelandic, is Desire of Ages. It is presently being prepared for publication. The ten-volume set, My Bible Friends, by E. G. Degering, was published as five volumes in 1982 .

Some of the above titles were published mainly for the benefit of church members, in which case the number of books sold can only be a few hundred, as there are hardly more than 500 Adventists. However, other titles published for a wider circulation have sold by the thousands. The 
children's books have been especially popular. Literature evangelists, mostly students, usually cover the entire country each summer. SDA publications are generally well received by the public.

\section{Bible Correspondence School}

The Bible Correspondence School was begun in 1948 by Axel Varmer. It presently offers six courses on Bible subjects. A course on health and healthful living is in preparation.

Although thousands of individuals have responded through the years to invitations to receive course materials, usually only a few dozen students are active at any given time.

\section{Radio Ministry}

The on 1y radio station in Iceland is under the control of the government. The Lutheran State Church broadcasts its Sunday worship services regularly. Other churches such as the SDA church and the Pentecostal church are permitted one such broadcast each year. Adventists have broadcast one religious service each year 1

since 1962. These broadcasts have generally been well received by the people of the country, but as they are limited to one each year, the potential for outreach through this avenue is very limited.

1 Braedrabandid, no. $7-8,1964$, p. 7 . 
Book and Healthfood Store

Fraekornid is a SDA book and healthfood store strategically located near the center of the capital, Reykjavik. It is financially viable and has a good potential for outreach, as the store meets certain felt needs of its customers, many of whom are non-Adventists.

Telephone Answering Service

A telephone service that is a 24-hour-a-day venture sponsored by the churches in Sudurnes and Vestmannaejjar since 1982 offers a taped recording of scripture and a short meditation. The focus is on meeting the spiritual needs of callers and on offering encouragement.

\section{A Summer Health Resort}

A summer health resort began operation at Hlidardalsskoli in July 1953. This venture was strongly health-oriented at its inception, but later developed into a vacation resort. With declining attendarce, it eventual1y closed down in 1967.

\section{Relief Work}

Poverty is almost non-existent in Iceland. In most cases, relief work in Iceland means providing clothes and financial help when homes burn or volcanic activities occur. However, the Dorcas societies have frequently sent large shipments of clothes to aid people in other countries. 
Closely related to the Dorcas work is the annual Ingathering campaign when funds are raised to help finance the extensive welfare, educational, and medical work the church operates in many countries around the world. This fund-raising program has a long and successful history in Iceland. Each summer groups of church workers and laypeople travel for about two weeks to every village and town in Iceland distributing the fundraising magazine, Kristileg Menning.

Icelanders are receptive to appeals for financial support for worthy causes. About 25,000 copies of Kristileg Menning are distributed annually, which means that the majority of Icelandic homes receive it.

\section{Five-day Plan for Smokers}

The Five-day Plan to aid smokers stop smoking was launched in Iceland in February, 1973. In the following decade dozens of seminars have been held throughout the country. Right from the beginning organizations concerned with public health have consistently supported this program. It found popular support among the public.

The one individual who has promoted this program for the church in Iceland more than anyone else is Jon H.

${ }^{1}$ My first contact with the SDA church was through an "Ingathering" visit. The magaine promoted the new boarding school, H1idardalsskoli, which caught my interest. This eventually led to my attending the school and later joining the church. 
Jonsson, an ordained SDA minister. He reports: "In the long run, there are slightly more than 50 percent of participants who permanently refrain from smoking."

\section{Gift Bible Plan}

The Gift Bible Plan was first introduced in 1967 at Akureyri. Eventually, this program led several individuals to join the SDA Church. It requires that visitations be made consistently to persons interested in the Adventist message. This is one way of taking advantage of the materials offered by the Bible Correspondence School. However, the giving of Bibles along with the BCS courses has now discontinued.

\section{Vacation Bible School}

The Vacation Bible School was also introduced in 1967 at Akureyri and was well received by children and their parents. The following year it was introduced to SDA lay-people in a summer-camp setting at Hiidardalsskoli with more than 150 children, mostly non-Adventist, attending. It proved to have great appeal to children and their parents. However, as the VBS program was not adopted by the SDA churches on a permanent basis, it was discontinued. The interest and enthusiasm generated among non-Adventists by the VBS program, indicates that this is still another useful agency for outreach.

\footnotetext{
${ }^{1}$ Braedrabandid, no. 4, 1982, p. 20.
} 
Summer Camp for Children

However, the VBS program did spark the annual children's summer camp at Hlidardalsskoli. Since 1974, approximately 180 children, most of whom are non-Adventists, attend each summer.

In 1974, President Bjarnason commented on the summer-camp program: "This seems to be a very good method for outreach." ${ }^{1}$ And in 1982, President Snorrason added: "Clearly, the summer camps provide the churches with an excellent work, an opportunity we cannot afford to overlook." ${ }^{2}$

Little has been done, however, to follow up on contact opportunities and goodwill created by the summer camps. Aside from Pathfinder work conducted by the Sudurnes Church for several years for summer-camp children in the towns of Reflavik and Grindavik, few other contacts have been made. Recently these popular Pathfinder clubs were discontinued due to a lack of leaders.

The Children's Storyhour

The children's storyhour (this is not a radio program) conducted in the Thordarsons home was a strong feature in their outreach program at Akureyri in 1966-70, and also for the Jonssons in the mid-seventies in the same town. This storyhour program was conducted for one hour

\footnotetext{
${ }^{1}$ Braedrabandid, no. $8-9,1974$, p. 1 .

2 Ibid., no. 4, 1982, p. 18.
} 
each Sunday afternoon and mostly followed the SDA. Sabbath School program for children. Usually between 60 to 100 children attended.

According to Jon H. Jonsson, "The storyhour seems to be very popular. Obviously, this is the kind of work that has great potential." However, this type of outreach has not been utilized to any degree elsewhere in the country, and presently no minister is located at Akureyri to continue the children's storyhour there.

\section{Summary}

During the second and third decade of this century, Seventh-day Adventists in Iceland conducted a vigorous program of public evangelism which led to the organization of eight new churches and companies (Reykjavik church had been organized previously to this). Five more churches were organized in the next two decades.

After Christian education became the dominant outreach program in Iceland Conference, from 1950, the rate of growth diminished markedly. Organization of a new congregation has not taken place since 1952. Of nine SDA houses of worship around the country, five have been sold without replacement.

The Seventh-day Adventist Church used to be the second largest denomination in Iceland, but is now the

Braedrabandid, no. 4, 1976, p. 15. 
fourth largest. Most other denominations presentiy enjoy a higher rate of growth than Adventists. 
CHAPTER IV

SDA CHURCH GROWTH IN ICELAND

\section{Introduction}

This chapter describes the findings from empirical research that focused on church growth in the Seventh-day Adventist Church in Iceland since 1950. The three major 1

parts include: (1) a survey of the experiences and attitudes of Seventh-day Adventists in Iceland; (2) an evaluation of the church growth function of Hlidardalsskoli (a SDA boarding school on secondary level; and (3), an evaluation of other methods employed by the church to achieve growth.

To accomplish this task, a survey instrument was prepared from two existing surveys, the Caring Church Surver and the New Member Survey, developed by the Institute of Church Ministry at Andrews University for use in North America. A few questions used in the two surveys were dropped and others added in order to make the new survey more appropriate for the Icelandic setting. The new survey gathered 78 items of information.

\footnotetext{
$1_{\text {This survey appears in appendix } A .}$
} 
The intended use of the survey instrument was to give an insight into the composition and background of the SDA membership in the Iceland Conference and to show what factors contributed to influence members to join the SDA Church. It was anticipated that by responding to the survey questions, participants would evaluate their own spiritual life and express their perceptions of the SDA Church, the pastoral ministry, and the effectiveness of present church-growth emphasis.

Further research was conducted in conference records, the official church paper, Braedrabandid, the minutes of the conference executive committee from 1950 to 1980 , and the roster of students attending Hlidardalsskoli since its beginning.

\section{Setting for the Survey}

The survey was conducted on October 8,1983 , during the period between the Sabbath School and the 11 o'clock worship service. Supplies for the survey were sent to the four churches that conduct Sabbath services regularly Reykjavik, Arnes, Sudurnes, and Vestmannaeyjar--and to the companies at Akureyri in North Iceland and at Faskrudsfjordur on the east coast.

The total attendance in the churches on 0ctober 8 was approximately 180. According to information obtained from those who conducted the survey, the attendance in each place was about average for Sabbath attendance. At a 
preparatory meeting with the Seventh-day Adventist ministers in Iceland in October, 1983, I was informed that approximately 200 church members could be considered regular church goers. The official church membership in Iceland in 1983 was 543.

The number of usable surveys returned was 137 ; this breaks down as follows: Reykjavik Church, 61; Arnes Church, 27; Sudurnes Church, 20; Vestmannaeyjar Church, 15; Conference Church (represented by the participating members at Akureyri and Faskrudsfjordur), 14 .

\section{How the Survey Was Conducted}

The individual selected to conduct the survey in each church or company received a letter (see appendix B) containing the following instructions:

1. Announce to the congregations that the conference executive committee had wholehearted $1 \mathrm{y}$ endorsed this survey and voted its approval.

2. Indicate that al1 the ministers in the conference were in full support of the project.

3. Explain the purpose of the research project and the function of the survey instrument--that it is an endeavor to obtain an $x$-ray picture, as it were, of the spiritual and social status of the church and its members and the attitude of the members toward matters of importance to the life and growth of the church. 
4. Explain that the survey could lead to a better ministry for the church members, more vigorous church life, and more powerful soulwinning work.

5. Explain that participants should not write their names on the survey (this would ensure each respondent of his or her anonymity).

6. Encourage members to respond honestly and sincerely so the survey may provide an accurate picture.

7. Encourage all to answer each question simultaneously. This enables the leader to explain each question only once.

8. Explain that the survey is intended to be answered only by baptized members in good and regular standing.

9. On the last page have the people write two or three words in each line, whatever first comes to their minds, but, as a leader, avoid giving examples as to how people could answer the questions.

10. Conduct the survey simultaneously in the following places: Akureyri, Faskrudsfjordur, Vestmannaejjar, Reflavik, Reykjavik, Selfossi, and Hlidardalsskoli.

11. Expect the findings to be published in Braedrabandid next Spring.

12. Have enough pencils on hand to enable all present to reply simultaneously.

${ }^{1}$ In April 1984, a copy of the survey results were sent to the conference president representing all the churches together. 
13. As soon as the survey is completed, gather all the papers and seal in a large envelope in the presence of the church.

14. Rindly send the papers to the researcher at the conference office, Skolavordustig 16, Reykjavik, as soon as possible.

Whereas Icelanders are unfamiliar with surveys, it was felt necessary to have the people deal with each question simultaneously to enable the leader to explain each question only once, thus reducing time needed for the survey. I personally conducted the survey in Reykjavik Church which is the largest SDA congregation in Iceland. Completing the survey took 28 minutes there, and generally took less than 30 minutes in the other churches as well. At, the end of the survey several elderly individuals complained that the time was too short for them to think through each answer. These persons would like to have taken the survey home and return it later. This possibility had previously been discussed among the ministers and ruled out as impractical.

Many church members in Iceland frequently visit churches other than their own on Sabbath. Therefore, it was considered important to conduct the survey at the same time in all the churches to prevent a possible inflation of numbers. Al1 who conducted the survey reported that the process was smooth and orderly. 
Whereas this kind of undertaking is rather unusual in Iceland and, as far as the Seventh-day Adventist Church is concerned, it had never taken place before, the task was approached with apprehension. However, the enthusiastic co-operation of the people, the ministers, and other church leaders greatly facilitated the taking of the survey.

\section{Procedure for Analyzing Data}

All the survey materials were promptly returned in their sealed envelopes to the conference office. I brought them to the campus of Andrews University where the survey data were fed into a computer for analysis and study. This computer analysis is based on the Andrews University Statistical Tallying Program: "TALLY.STATL". The help and counsel of computer consultants was enlisted. The format chosen for the computer print-out was to a large degree in keeping with that of the Institute of Church Ministry for the Caring Church Survey.

Present survey is a study of trends in the church life and in the views and attitudes of church members relative to growth and well-being in the church. In this context the church members' perceptions of their church, their own spiritual experiences, and their ministry inside and outside the church fellowship are sought. Individual responses brought out by the survey are likely to be subjective. One individual may, perhaps, consider his/her 
own activity in the church as a considerable contribution to its ministry, while another individual contributing similar service may consider his/her contribution as minimal. Still, the members' perceptions are important for a study of this nature.

Where participants in the survey were given several choices for their answers (i.e. on a scale of 1 to 5 ), responses number 1 and 2 are generally considered negative, and responses number 4 and 5 are considered positive.

The profile (see appendix A) reveals the actual number as well as percentage of respondents who selected each possible choice in the survey. All percentages have been rounded out. From 10 to 20 percent, and sometimes more, of the participants did not respond to many questions. In spite of this, it is felt that this is an accurate indicator of the trends and conditions in the Seventh-day Adventist Church in Iceland today as these are perceived by the members.

\section{Limitations}

As referred to above, two existing questionnaires were followed in the preparation of this survey. The questionnaire does not test for certain normal variations, i.e. income and occupation. It was felt to be too offensive to ask respondents about their income, and to state one's occupation would, in the small SDA 
congregations in Iceland, amount to giving his/her

identity. However, age, sex, and education in Adventist institutions of respondents was tested for.

Total education is probably one of the most important variables in helping researchers understand the social location of the cohort of people under study. The questionnaire followed did not test for level of education achieved outside Adventist circles. Unfortunately, this is an oversight in this qustionnaire.

Attitudes towards the SDA Church on the part of the wider community were not studied. Such a study might prove to be profitable for the church.

It should be kept in mind that this survey reflects only the views and experiences of those church members in the Iceland Conference of Seventh-day Adventists who attended church on October 8, 1983, the day the survey was taken.

\section{$\frac{\text { Members' Receptivity }}{\text { of Survey }}$}

The survey was well received by church members and there was a good spirit prevailing during the proceedings. Immediately after the survey, as well as during the following days, many individuals expressed their interest in and appreciation for the survey. These individuals are eagerly waiting to read the final results.

However, the survey brought out various spiritual and social needs of the church members in Iceland. It 
also indicated that the majority of Adventists desire to be more active in witnessing for their faith. This should be an encouragement to the church leaders.

Several important conclusions can be drawn from the study of the church's history and the survey. These findings seem to indicate decline in church growth and serve as a challenge for improved church growth--depending on how the findings are received by those who make up the church today.

\section{What the Survey Reveals}

Tenure of Membership

Church-attending Adventists in Iceland are a rather mature group of people with 74 percent having been members more than ten years ( 54 percent more than twenty years). Only 3 percent are in their first year of membership, and 10 percent have been members five years or less. The remaining 15 percent have been members from six to ten years (see figure 3 ).

This trend towards increased membership tenure becomes evident in most of the SDA churches in Iceland. The one clear exception is Sudurnes Church. Individuals in this church who have been baptized church members for five years or less make up 25 percent of the membership. Each of the remaining three categories also has 25 percent of the membership, thus making all age-groups well represented. 

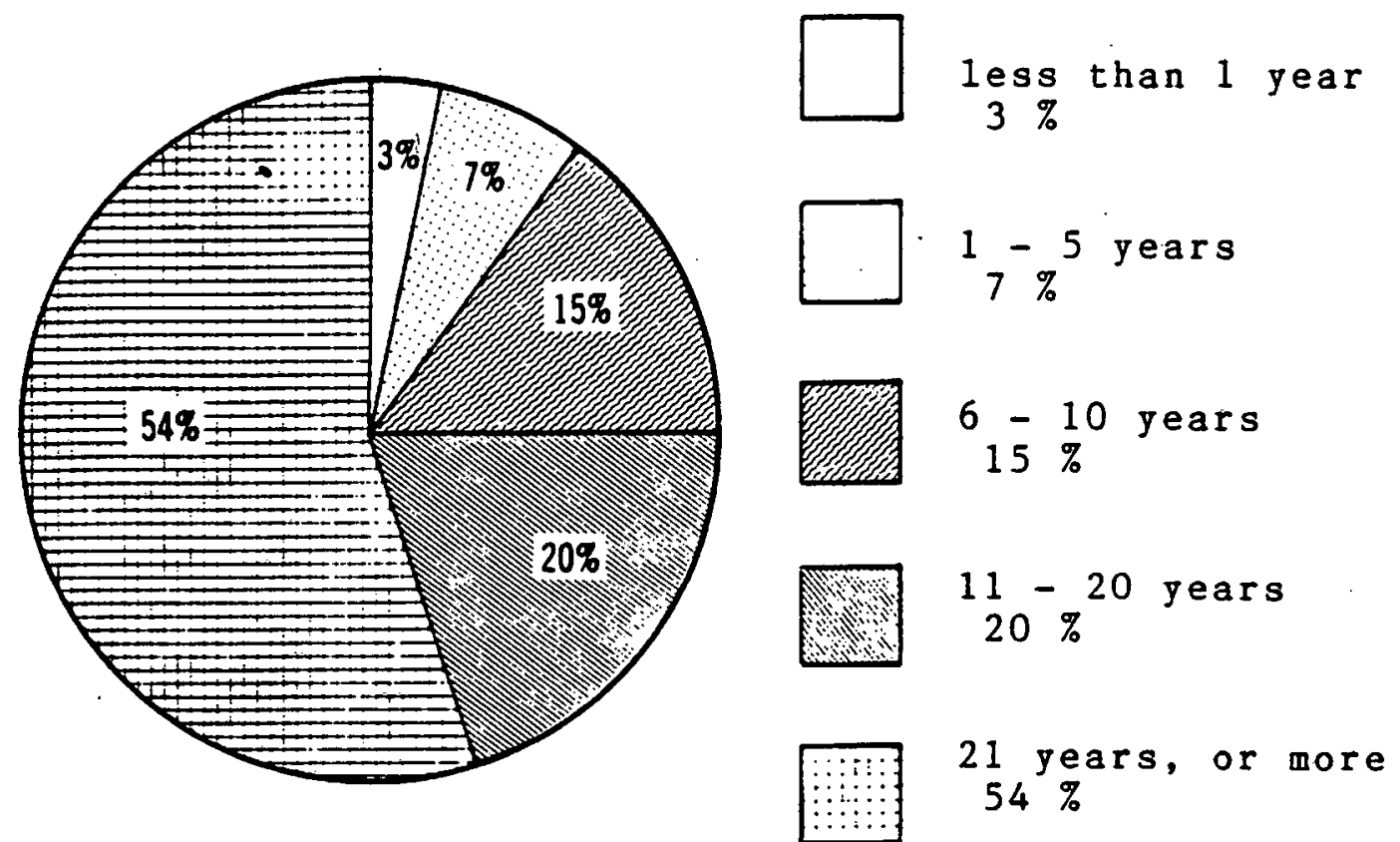

Fig. 3. Tenure of Membership

In the Reykjavik Church, which is the largest congregation, 64 percent have been members twenty-one years or longer. Combining these with those who have been church members eleven to twenty years increases the total to 75 percent.

However, all the respondents ( 100 percent) in the Vestmannaeyjar Church have been members of the SDA Church eleven years or longer. In the Conference Church, 36 percent of the respondents have been Adventists six to ten years, and no one present for this survey has been a church member five years or less.

Three percent of the respondents indicated they had joined the SDA Church within the previous twelve months. At first glance this seems to indicate increased 
accessions to membership in this one year over the four preceding years ( $7 \%$ of respondents have been members $1-5$ years), when the average annual percentage of accessions indicated by the survey was 1.75 percent. However, the official membership records show a net loss of three members (from 549 members in 1981 to 546 members in 1982) for the twelve month period.

From 1978 to 1983 the average annual net increase in membership was 2.4 new members. Whereas the membership records do not adequately reflect missing and apostatized members, there are indications that accessions to membership in the SDA Church in Iceland do not keep pace with deaths, apostasies, and transfers.

\section{Distribution of Respondents by Age}

A study of the statistics on $S D A$ church members in Iceland, according to age groups, gives the following profile: The smallest age group, 8 percent, is made up of individuals who are 19 years of age and younger. Twenty-three percent are members who are 20-35 years of age; 28 percent are $36-50$ years of age; 23 percent are 51-65 years of age, and 17 percent are 66 years or older.

With 8 percent of church members forming the youngest age group ( 19 years or younger) and 40 percent

${ }^{1}$ General Conference of Seventh-day Adventists, Statistical Report (Washington, D.C.: Review and Herald Publishing Association, 1981-1982.

2 Braedrabandid, March 1982, p. 6 . 
being 51 years, or older, the present membership seems to be developing into a congregation of elderly people ${ }^{1}$ (see fig. 4).
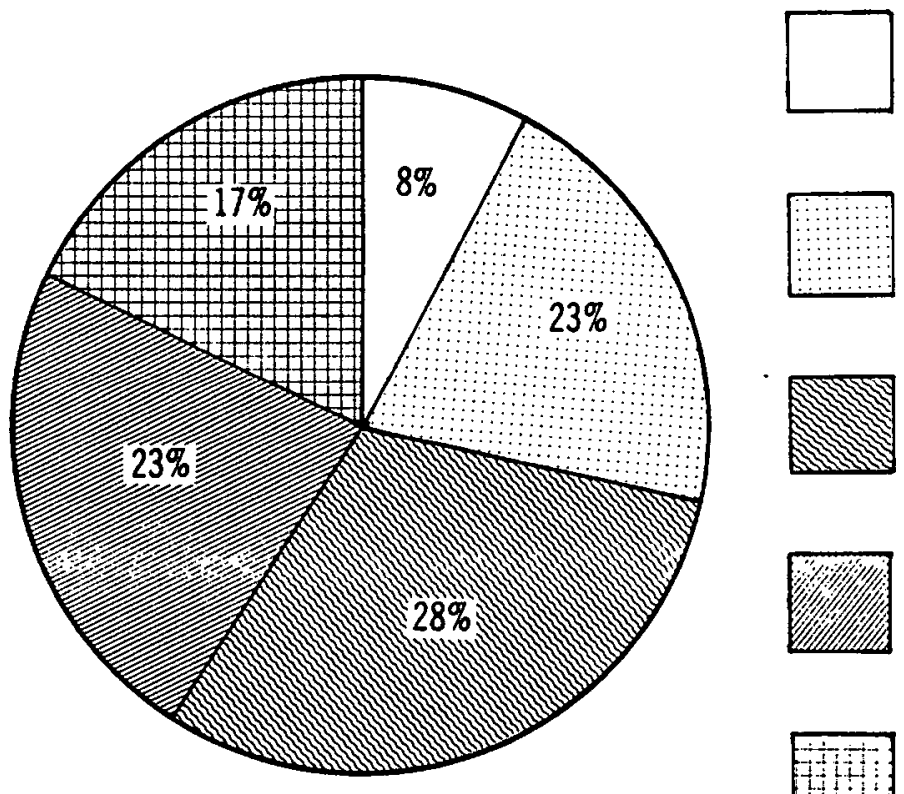

19 years of age or younger $8 \%$

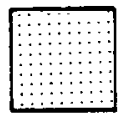

$20-35$ years of age $23 \%$

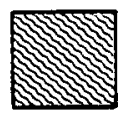

$36-50$ years of age $28 \%$

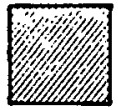

$51-65$ years of age $23 \%$

66 years, or more $17 \%$

Fig. 4. Distribution of Respondents by Age.

Sex and Marital Status

Of those who responded to the survey, 58 percent were females and 42 percent were males (see fig. 5). Furthermore, the church membership is made up primarily of married people, 74 percent; while unmarried individuals, 18 percent; 7 percent widows and widowers; and 1 percent divorced or separated make up the remainder.

1 This reality was indicated by the conference president, Erling $B$. Snorrason, when he reported to the constituency from the general meeting of the church, called in June 1981, to discuss the future of Hlidardalsskoli. He stated: "People expressed far greater concerns about the diminishing enrollment at the school. If nothing changes, the number of teenagers of the age to attend Hlidardalsskoli in coming years is less than 20 , 


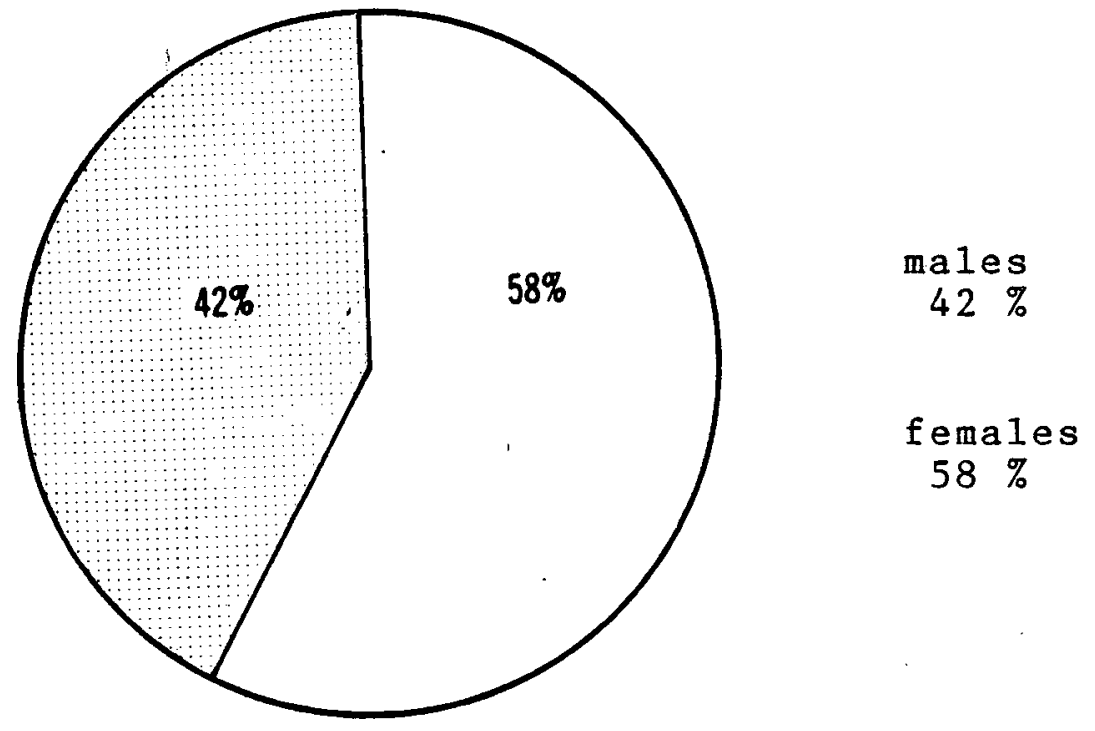

Fig. 5. Male-Female Distribution of Respondents

Adventist Background of Members

Response to the question, "Was at least one of your parents a Seventh-day Adventist during your first 12 years?" indicates that 59 percent of Seventh-day Adventists in Iceland had an Adventist background before joining the church, while 41 percent came from a non-Adventist background (see fig. 6). of individuals 19 years and younger--

64 percent had an Adventist parent; of individuals $20-35$ years of age--

61 percent had an Adventist parent;

and some years only about 15," Braedrabandid, no. 3, 1981, p. 8 . 
of individuals 36 - 50 years of age--

64 percent had an Adventist parent;

of individuals $51-65$ years of age--

66 percent had an Adventist parent;

of individuals 66 years and older--

30 percent had an Adventist parent.

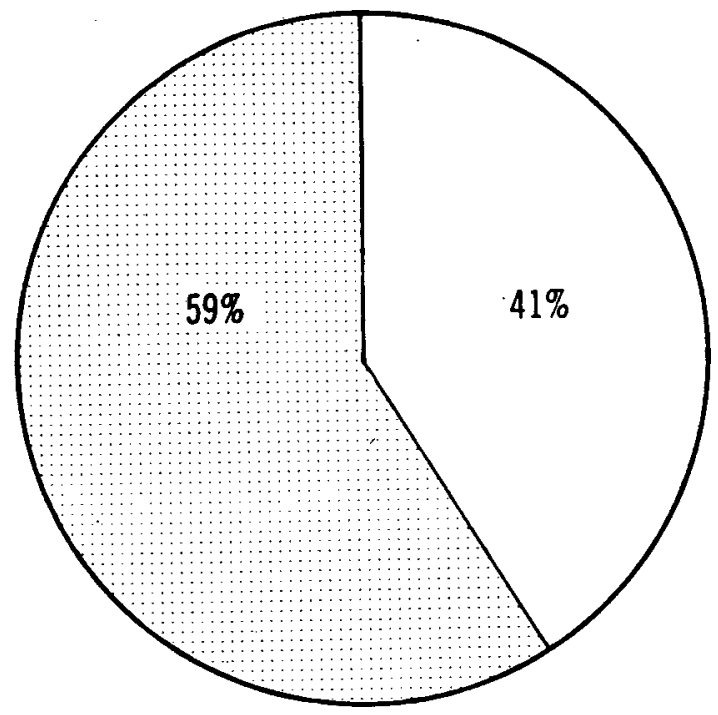

At least one SDA parent $59 \%$

No SDA parents

$41 \%$

Fig. 6. Adventist Background of Members

These figures reveal that growth in the Seventh-day Adventist Church in Iceland is largely biological growth; that almost two-thirds of the members under 66 years of age were raised in an Adventist atmosphere. Consequently, this indicates that one-third of those who presently are members joined the church through the various outreach programs. This also seems to indicate that one must go back several decades into the history of the church in 
Iceland to find a period when conversion growth and not biological growth was the greatest contribution to the increase in church membership.

In the churches of Reykjavik, Arnes and

Vestmannaeyjar, 56 percent of the members, 78 percent, and 87 percent, respectively, were raised in an Adventist atmosphere. In contrast, 30 percent of the members in Sudurnes Church come from an Adventist background.

\section{Educationa1 Background of Members}

Fourteen percent of respondents attended church school in grades one to three, and 17 percent attended in grades four to six.

Adventist education in Iceland on the elementary level has not been provided continuously in every church except in Vestmannaeyjar. This may have contributed to the fact that 47 percent of the church members never attended an SDA church school (grades one to six).

As stated in chapter 3 , the Vestmannaeyjar Church school was recently closed down after more than half a century of operation. The Sudurnes church school and the Arnes church school struggled for survival in recent years but are now closed. Sudurnes church school was closed because of the unavailability of a teacher. The Regkjavik church school, which was closed from 1966 to 1976, remains the on1y functioning church school. 
The survey further indicates that 28 percent of the church members never attended church schools in grades seven to ten, while 41 percent attended these grades for one or more years. Twenty percent of the church members attended grades eleven to fourteen in SDA schools (some may have attended schools on this level in other countries). Twelve percent indicated they had pursued studies in SDA schools one or more years beyond the fourteenth grade.

\section{Influential Factors That Led People to Join the Church}

Respondents were asked to rank order several suggested factors that influenced them to join the SDA church. The factors rated as the most influential are shown in table 5 listed below. Choices 4 and 5 representing "fair amount" and "great deal" of influence, respectively, are combined in the list of percentages.

These factors are described briefly as follows:

\section{$\underline{\text { SDA parent }}$}

It has already been shown that children of church members have for several decades made up the majority of those who joined the church. Fifty-four percent of the

- ${ }^{1}$ Some respondents credited two or more factors for influencing them to the same degree, i.e., one may have given both a parent and a pastor the credit for "great deal" of influence, while another may have granted the same amount of influence to, say, public meetings, SDA 
TABLE 5

FACTORS INFLUENCING DECISION TO JOIN CHURCH

(Churches with Highest and Lowest Percentages Shown)

\begin{tabular}{|c|c|c|c|c|c|}
\hline Factors & $\begin{array}{c}\text { Average } \\
\%\end{array}$ & \multicolumn{2}{|c|}{$\begin{array}{l}\text { Church with Highest \% } \\
\text { Church }\end{array}$} & \multicolumn{2}{|c|}{$\begin{array}{l}\text { Church with Lowest \% } \\
\text { Church }\end{array}$} \\
\hline SDA parent & 54 & Vestm. & 87 & Conference & 21 \\
\hline Pastor & 40 & Sudurnes & 50 & Arnes & 26 \\
\hline Public meeting & 33 & Sudurnes & 55 & Vestm. & 7 \\
\hline SDA book/pamphlet & 32 & Conference & 42 & Vestm. & 27 \\
\hline Hlidardalsskoli & 32 & Arnes & 51 & Reykjavik & 20 \\
\hline $\begin{array}{l}\text { Church member } \\
\text { I knew well }\end{array}$ & 30 & Sudurnes & 50 & Vestm. & 7 \\
\hline $\begin{array}{l}\text { Bible study } \\
\text { in home }\end{array}$ & 26 & Conference & 36 & Vestm. & 13 \\
\hline SDA church school & 25 & Vestm. & 67 & Sudurnes & 15 \\
\hline $\begin{array}{l}\text { SDA relative- } \\
\text { not parent }\end{array}$ & 19 & Vestm. & 33 & Conference & 14 \\
\hline $\begin{array}{l}\text { Bible Corres- } \\
\text { pondence School }\end{array}$ & 11 & Rvk., Vestm. & 13 & Sudurnes & 10 \\
\hline
\end{tabular}

respondents place their own parents at the top of the list of factors influencing them to join the church. This finding is supported by the 59 percent of respondents who had at least one Adventist parent during his/her first twelve years in life.

Pastor

With 40 percent the pastor ranks as the second highest in the order of factors influencing people to join the SDA Church. This finding may be of special intrest to

books and pamphlets, and Bible studies in the home. Therefore, total percentages do not add up. 
Adventists in Iceland, who, until recently, have not benefitted from the continuous presence of a pastor. Since 1970 the Sudurnes Church has had a pastor on a regular basis; Vestmannaeyjar Church has not had a full-time pastor for two decades, and through the years, the Arnes Church has benefitted mostly from whatever ministerial services could be rendered by the faculty of H1idardalssko1i. In 1976 and 1977, a ful1-time pastor served Arnes Church, and again since 1982. In the largest church, Reykjavik, the pastorate was usually the responsibility of the conference president. This arrangement ended in 1980 when the Reykjavik Church received a fu11-time pastor.

In view of the limited pastoral care given to the congregations in the past, the high ranking of the pastor as an influencing factor seems to indicate the potential the local pastor may have for boosting church growth. One can only speculate on what further increase in membership there might have been if each church had enjoyed the services of a resident, fu11-time pastor for several decades. Furthermore, one can hardly fail to notice that in the one church (Sudurnes Church) which has had a ful1-time pastor for the longest continuous period--since 1970--fully 50 percent of the members give the pastor considerable credit for influencing them to join the church. 


\section{Public meetings}

Public meetings are ranked as third most influential ( $33 \%$ ) in encouraging people to join the Seventh-day Adventist Church. This is a noteworthy finding, especially since public evangelistic meetings frequently seem to lack in the necessary preparation and cultivation of interested individuals prior to the meetings, and often fail to have vital follow-up ministry after the meetings as well.

Perhaps the Icelandic ministers have unwittingly adopted the methods of the show-case demonstrations in evangelism conducted in Iceland by several guest 1

evangelists from other countries. To accomplish church growth, the conference leadership seems to have formed the habit of relying on visiting evangelists--who in many cases must speak through interpreters when presenting their lectures.

In spite of the meager results from the evangelistic series conducted by the foreign evangelists, the respondents rank public meetings relatively high in influencing them to join the church. This may indicate that Icelandic ministers who have conducted evangelistic meetings through the years have met with some success. Unfortunately, no records were available on the number of baptisms that can reliably be contributed to public

${ }^{1}$ See 1 ist of guest evangelists, pp. 103-106. 
meetings conducted by local evangelists. However, table 8 in appendix $C$ offers a clue. Here we find that a total of 146 members from non-Adventist background joined the SDA Church in Iceland from 1950 to 1982 without H1idardalsskoli influence. In most cases these individuals have been influenced by public meetings to join the church. Most older members joined the church before guest evangelists began coming to Iceland, and before the secondary school program was well established.

The members of Sudurnes Church placed public meetings at the top of their list ( $55 \%$ ) and this is understandable in the light of their predominantly non-Adventist background (70\%).

SDA books and pamphlets

In terms of influencing people to join the church, SDA books and pamphlets rank as fourth most influential factor (with $32 \%$, combining choices 3 and 4 , representing "fair amount" and "great deal" of influence, respective1y).

Seventh-day Adventists in Iceland have had rather limited access, in the vernacular, to the many SDA books commonly used in some other countries. Accessability has improved in recent years as several books have been 1 published by the church in Icelandic. The Sabbath School Lessons may, perhaps, be a major factor in this

${ }^{1}$ See section on publishing work, pp. 106-108. 
rating (see "A Few Comparisons between Individua1 Churches", pp. 149-154).

Fifty percent of respondents read E. G. White books "sometimes," and 20 percent read them "usually" or "always." In comparison, 39 percent of the respondents read the Bible "sometimes," and 54 percent read it "usua11y" or "always."

The Conference Church, whose members do not benefit from regular church services and pastoral ministry, credit SDA books and pamphlets with exerting second greatest influence ( $42 \%$, with "fair amount" and "great deal" of influence combined) on them to join the SDA Church. For members of the Conference Church, a pastor (43\%) had been the most influential factor in leading them to join the SDA Church.

\section{Hlidardalsskoli}

The secondary school was tied in fourth place with SDA books and pamphlets in the list of factors that led respondents to join the SDA Church.

This co-educational boarding school has long been considered the greatest contributor to church growth in the Seventh-day Adventist Church in Iceland. However, as noted above, participants in the survey rate other factors above it in their experience.

When researching the records of the Iceland Conference, I was impressed by the importance given to the 
role of this educational institution in the plan of the conference for outreach and church growth. Therefore, it is necessary to devote a special section later in this chapter to further discussion about this institution and its effect on church growth.

\section{SDA acquaintances}

The influence of a "church member I knew we1I" places fifth (with $30 \%$ ) in the order of factors that influence people to join the SDA Church. The members of the Sudurnes Church especially seem to exert much influence on their non-Adventist friends to join the church, as 50 percent of the present members state that Seventh-day Adventists they knew well before joining the church had a "fair amount" (30\%) to "great deal" ( $20 \%$ ) of influence on them.

Seven percent of the members of Vestmannaeyjar Church give SDA acquaintances credit for a "great deal" of influence, and none at al1 for a "fair amount" of influence. Still, 60 percent of the members of this church claim they have "many" close non-Adventist friends and 40 percent have "a few." These findings indicate that the Sudurnes Church, whose members come mostly from a non-Adventist background, has greater success in attracting non-Adventists into their church fellowship 
than the Vestmannaeyjar Church whose members come mostly from an Adventist background.

\section{Bible studies}

With 26 percent of the respondents, "Bible studies in my home" ranks in sixth place on the list of factors influencing people to join the SDA Church. In light of the fact that in other countries most individuals receive a series of Bible studies before joining the church, it seems this factor should be rated more highly. However, as most members in Iceland had an Adventist background before baptism, they naturally rated other factors, such as parent, pastor, and SDA books, as exerting greater influence on them to join the church.

Members of the Conference Church rated Bible studies highest ( $36 \%$ ) in influencing them to join the church. These individuals do not have a pastor and do not benefit from the support system a fully functional church can provide.

The low rating accorded "Bible studies" as an instrument of evangelism may also reflect the lack of trained lay-people to give Bible studies. However, the interest in rendering this type of witnessing activity is definitely present among the majority of Adventists in

\footnotetext{
$149 \mathrm{ff}$.

$1_{\text {See }}$ "Comparisons Between Individual Churches," p.
} 
Iceland Because of the possibilities inherent in it, this item is also treated later.

\section{SDA church schools}

The SDA church schools in Iceland have not been operated continuously in every church. Sti11, 25 percent of the members rate the church schools as a significant factor (in seventh place) in their experience leading to their joining the church. This corroborates the experience of members of the Vestmannaeyjar Church, where a school was open for more than half a century; 67 percent (combining "fair amount" and "great deal" of influence) of the members give credit to their church school, placing it next to the top item, "parent" (87\%). On the other hand, members of the Sudurnes Church, where a school has been operated for the least number of years, give 15 percent to this influence factor.

The survey further shows that 56 percent of church members do not have children of school-age. Of parents who have school-age children, 18 percent state their children attend public schools, and 17 percent have their children attend SDA schools.

\section{SDA relative}

Respondents gave SDA relatives, other than parents, a 19 percent rating, placing this item as the eighth on

$1_{\text {See }}$ "Witnessing Activities of Church Members," p. 
the 1 ist of factors influencing people to join the church. Once the respondents had joined the church, support they received from their family members varied considerably. Forty-nine percent agreed (or agreed strongly) with the statement: "My immediate family members strengthen my relationship with God," while 19 percent disagreed.

\section{Bible Correspondence School}

The rating of the Bible Correspondence School in ninth place among factors influencing people to join the SDA Church may be considered rather low with 11 percent. The Bible Correspondence School is most effective in its supporting role to other programs of the church. When these are neglected, are weak, or absent, the Bible Correspondence School becomes less effective. Its effectiveness is enhanced when its correspondence courses are tied in with the various outreach programs of the church, i.e., Daniel and Revelation seminars, healthrelated seminars, Dorcas work, and public evangelism. The Bible Correspondence School materials become especially helpful when they are consistently applied to a vigorous visitation program.

\section{Members' Evaluation of Their Own Spiritual Life}

\section{Church Attendance}

The church members who attended church on the day this survey was taken must be considered diligent church 
goers, for 89 percent usually or always attend Sabbath School, and 81 percent usually or always attend divine service.

Weekly prayer meetings are a regular feature in some churches, while in others prayer meetings have not always been conducted on a regular basis. However, 16 percent claim they always attend prayer meetings, 27 percent usually do so, 29 percent sometimes, and 7 percent never. Prayer meetings in homes are obviously rare events since only 4 percent attend these regularly, and 30 percent do so usually or sometimes.

\section{Family Worship}

Twenty-five percent of Icelandic Adventists conduct family worship daily, and another 13 percent usually do so. It has been shown that when it comes to evaluating their relationship with God, 49 percent consider themselves as having a close relationship with God, while 8 percent have little relationship with God. Seventyseven percent consider themselves to be at peace with God, while 7 percent claim they do not have that peace.

\section{Members' Evaluation of the}

\section{Pastora1 Ministry}

Outreach Emphasis

To the question, "What emphasis does your pastor place on soulwinning?" 40 percent of respondents are of the opinion that their pastor gives high priority to 
soulwinning. Forty-four percent of the respondents think that the conference places little, or too little, emphasis on public evangelism!

Frequent exchange of pulpits by the pastors seems to be popular among the members, as 29 percent desire to have a visiting preacher twice each month, while 39 percent would welcome a visiting speaker once each month.

\section{Pastoral Visitations}

As far as pastoral visitation is concerned, Adventists in Iceland feel that they are neglected. About 35 percent of the respondents claim they are never visited by a pastor, and 51 percent indicate they are seldom visited. Only 3 percent feel they are visited frequently by a pastor. One should be cautious in interpreting these figures, which are likely to be elastic in meaning. One church member may be satisfied with one or two pastoral visits each year and consider this "often," while another church member may not be satisfied with less than a monthly visit on regular basis and still consider this as "sometimes."

Only 4 percent of the respondents felt that the elder1y are sufficiently visited, while 76 percent disagreed with this view. Similarly, only 7 percent think that the young are visited frequently enough, and 66 percent do not think so. Sixty-five percent of the 
respondents in a11 age groups are dissatisfied with the infrequent pastoral visits.

\section{Pastoral Tenure}

When asked how long they wanted their pastors to stay in each parish, 40 percent of the respondents were of the opinion that "a good pastor" should serve the same church from four to seven years; 16 percent wish to limit the tenure to three years or less; and another 16 percent desire to have the same pastor eight to ten years; 15 percent want the pastor to remain more than ten years.

\section{Members' Perceptions of the Church}

Soulwinning

Forty-four percent of the respondents (combining choices 1 and 2) do not consider their church a soulwinning church." Only 15 percent do rate it as a soulwinning church (combining choices 4 and 5 ). Twenty-two percent are of the opinions that individuals brought into the church through evangelistic meetings generally do not remain long in the church.

Standards of the Christian Life

Sixty percent of respondents are of the opinion that the church upholds high standards, and 4 percent disagree with this view. 


\section{Friend1iness}

Fifty-three percent of respondents find the church to be warm and friendly, while 14 percent claim that it is cold and rejecting. And while 8 percent of respondents do not feel at home in the church, there are 73 percent who feel very much at home in the church.

\section{Activating New Members}

Fifty-three percent of respondents think that new members are given ample opportunity to participate in church activities, but 10 percent disagree with this view. And while 16 percent of respondents believe that new members are neglected; 42 percent think the opposite is true.

\section{Young People}

Seventeen percent of the respondents believe the young people in the church are neglected as far as involvement in church activities is concerned, but 47 percent believe the contrary. When the actual number of respondents (115) to this question are broken down further according to age-groups, the results show that four ( $36 \%$ ) of eleven respondents, 19 years and younger, feel that young people are not given enough opportunity to be involved in church affairs; six (21\%) of twenty-eight respondents, who are $20-35$ years old are of same opinion, and twelve (16\%) of seventy-six respondents who are 36 years and older think likewise. 


\section{4}

This indicates that more than one-third of the youngest age group desire to be more actively involved in church activities. The dissatisfaction decreases as the members become older. A plausible explanation for this improvement could be that when the youth enters the older age groups, they are given more opportunity for participation in church affairs. It would seem that the congregations have some untapped resources waiting to be of service.

To the question "What do you think should be done more of, or better, in the church?" work for children and gouth received the second highest number of responses, second after "unity." Coupled with this felt need is the desire for more visitation to the young people ${ }^{1}$.

\section{Sabbath Services}

Fifty-five percent of the respondents consider the Sabbath sermons interesting, but 21 percent indicated they are uncomfortable about bringing a visitor to Sabbath School. It would be worthwhile to discover the reason for this attitude so that steps could be taken for improvement.

Public Image of the Church

Fifty-six percent of the respondents think the public has a high opinion of the Seventh-day Adventist

$$
{ }^{1} \text { See "Pastoral Visitations," p. } 141 .
$$


Church, but 12 percent disagree with this view. Among the church programs that may have enhanced the public image of the church are the annul distribution of the ingathering paper; the services rendered by the Dorcas societies; the schools; and the Five-day Plan for smokers.

\section{Witnessing Activities of Church Members}

\section{Soulwinning}

Most Adventists in Iceland consider themselves i11-prepared for soulwinning activities and desire to do something about it.

Forty-nine percent feel they have little preparation or none at all for this task; only 1 percent felt they were "very well prepared". Nevertheless, 30 percent can speak easily about their faith to others, and 22 percent have engaged in some kind of soulwinning work during the last twelve months. Sixty percent report no soulwinning activity at all.

It should be encouraging to church leaders to learn that 64 percent of the respondents desire to participate in a training seminar for active soulwinning work. The members of Arnes Church are foremost in this respect, for 78 percent desire such training. Eighty percent of the respondents indicate they have not participated in such training during the last ten years. This does not necessarily indicate that in the past church members lacked interest in soulwinning work; it indicates the 
absence of successful or frequent enough training. seminars. The conference records that I studied made no mention of the Spiritual Gifts Inventory (see appendix E), by which church members could be aided in the discovery of their spiritual gifts.

The need for training is further emphasized by the fact that only 13 percent in the Vestmannaeyjar Church, 15 percent in the Arnes Church, and 20 percent in the Reykjavik Church had conducted Bible studies for non-Adventists during the preceding twelve months. In this area, members of the Sudurnes Church (35\%) were most active.

Respondents to the question, "Have you conducted Bible studies with a non-Adventist during the past 12 months?" replied positively according to following age groups.

$$
\begin{aligned}
& 19 \text { years and younger - } 36 \text { percent } \\
& 20 \text { - } 35 \text { years of age - } 19 \text { percent } \\
& 36 \text { - } 50 \text { years of age - } 15 \text { percent } \\
& 51 \text { - } 65 \text { years of age - } 22 \text { percent } \\
& 66 \text { years, and older - } 9 \text { percent. }
\end{aligned}
$$

This makes the youngest age group, which also is the smallest, the most active in the giving of Bible studies to non-Adventists.

Seventy-seven percent of respondents are not consciously responsible for having influenced an individual to join the church during the last three years. 
Nine percent indicate they have had a part in the conversion of one or more individuals. In this connection, it should be noted that 10 percent of respondents indicate they never pray for the conversion of specific people; 45 percent do so sometimes, 12 percent do usually, and 18 percent always do. Furthermore, 20 percent of the respondents have consciously sought to lead a non-Adventist relative to Christ.

To the comprehensive statement, "I help my neighbors with their personal problems," 15 percent state that they do so usually or always, but 17 percent claim they never do. Furthermore, in response to the statement, "I witness in every day activities," 21 percent indicate they usually or always do, and 36 percent do so sometimes. Twelve percent claim they never witness to others. By their own admission, Icelandic Adventists are ill-prepared for soulwinning activities. However, they desire to attend training seminars in order to improve their soulwinning skills. One-third of the respondents believe it is actually easy for them to speak about their faith to others. The youngest church members seem to have been the most active in giving Bible studies to nonAdventists.

\section{Relief and Community Services}

There are two main types of services which the SDA Church in Iceland renders to the community--the Dorcas 
work (welfare and relief) and the Five-day Plan for Smokers.

The four Dorcas societies actively serve specific needs of the people as opportunities present themselves. As social standards in Iceland are high, welfare work is not a major outreach avenue. The help provided is mostly in the form of clothes and financial aid. During the twelve months prior to the survey, 53 percent of the female respondents had participated in Dorcas work. Furthermore, 56 percent of the respondents claim to have participated in the annul Ingathering campaign--the fundraising drive for the support of the world-wide relief, medical, and educational work conducted by the SDA Church.

The Five-day Plan to aid smokers to stop smoking has been well received by the public, as is evidenced by the enrollment of hundreds of smokers in dozens of seminars through the years. As noted above, the long-term results are "slightly more than 50 percent of participants who permanently refrain from smoking." In spite of the popularity of the program, it does not seem to have contributed much to growth in the SDA Church in Iceland (see appendix A on responses to question no. 77 in the profile). The survey further indicates that 1 percent of the respondents have worked for or assisted 
in the Five-day Plan. Still, this program may have helped enhance the public image of the SDA Church.

It seems that such a popular program could serve as an ideal springboard for further outreach for the church. However, the absence of follow-up programs which would serve to bring participants into further contact with the church leaves much to be desired. It would seem that the Five-day Plan could play a significant role in a comprehensive strategy for church growth in Iceland.

\section{A Few Comparisons between} Individual Churches

Focusing on the interests and habits in religious life that characterize the individual congregations may help to identify areas in which they are especially strong or weak. This exercise might serve to encourage church members to maintain their strength in areas where they are strong and to endeavor to improve in areas in which they are weak. The survey reveals that each congregation has its strong points. Self-examination can be a painful experience, but it may help individual congregations toward a more fruitful experience in terms of church growth.

On the question concerning a close relationship with God, members of Reykjavik Church scored highest, 62 percent (combining choices 4 and 5). The Conference Church follows with 58 percent, while the rest of the churches lag behind considerably. However, most Icelandic 
Adventists consider themselves at peace with God--80 to 85 percent of the members of three churches replied positively to this question, and two remaining churches responding positively with 70 and 64 percent.

Members of Vestmannaeyjar Church seem to be the most diligent in attending prayer meetings ( 86 percent usually or always attend). Ninety-six percent of the Arnes Church usually or always attend divine services, while full 100 percent usually or always attend the Sabbath School. Close behind comes the congregation of the Sudurnes Church with 95 percent of its members usually or always in attendance at both the Sabbath School and the divine service.

Describing churches in terms of soulwinning success, 45 percent (combining choices 4 and 5) of the members of Sudurnes Church consider themselves as members of a soulwinning church; 15 percent in the Reykjavik Church consider themselves as part of a soulwinning church. The Arnes Church and the Vestmannaeyjar Church did not score any choices in 4 and 5 .

Ninety-five percent (combining choices 4 and 5 ) of respondents in the Sudurnes Church see themselves as warm and friendly, but members of the other churches see themselves as lagging far behind in this respect. According to other self-evaluations, members of the Sudurnes Church ranked themselves highest in terms of welcoming newcomers and activating new members into the 
church programs. Perhaps this is the result of it being the youngest congregation in terms of membership tenure. Also the fact that more than two-thirds of its members came from a non-Adventist background may be a contributing factor.

The members of Sudurnes Church $(65 \%)$, the Conference Church (64\%), and of Vestmanneyjar Church $(60 \%)$ have the highest percentage of close friends among non-Adventists. Arnes Church and Sudurnes Church have the greatest representation of individuals in the younger age groups and the fewest in the older age groups.

Considering the reading habits of the members of the various congregations, Vestmannaeyjar Church ranks itself at the top with 100 percent of its members reading al1 of the youth paper, and 100 percent reading all or almost all of the church paper. The Sabbath School Lesson seems to command considerably less interest since the percentage of members reading all of the $\underline{\text { SSL }}$ is 60 percent for the Vestmannaeyar Church and less for the other churches. In the Sudurnes and Arnes Churches 30 percent read all of the SSL regularly.

As mentioned above, the members of the Vestmannaeyjar Church rank themselves as the most avid readers of the church's publications ( $100 \%$ read all of the youth paper; 100 percent read all or almost a11, of the church paper, and 73 percent read a11, or almost a11 of the Sabbath School Lessons). They also have a large 
number of non-Adventist friends. However, they do not consider themselves a soulwinning church (see above).

On the other hand, the members of the Sudurnes Church who do not rate themselves as avid readers of the church literature ( $30 \%$ read all of SSL regular1y) also have a large number of non-Adventist friends. They have a considerably higher rate of success in influencing people from a non-Adventist background to join the SDA 1 Church.

The difference between these two congregations in soulwinning experience perhaps could be explained by the fact that the members of Vestmannaeyjar Church, whose membership tenure is higher than in any of the other churches ( $100 \%$ of respondents in Vestmannaeyjar Church have been members 11 years, or longer), have been without a pastor for two decades.

The members are devoted to the church, as is evidenced by their church attendance and avid reading of the church publications, but although they have a large number of non-Adventist friends, they are less involved in witnessing activities. On the other hand, the members of the Sudurnes Church, being younger in the Adventist faith and have had a pastor for fifteen years, are more active

${ }^{1}$ See 1 ist of influence factors on p. 131 ("church member I knew well", 50 percent; "public meetings", 55 percent). 
in witnessing about their faith among their many nonAdventist friends.

This suggested explanation is further supported by the responses given by the members of Arnes Church, 67 percent of whom rate themselves as "not a soulwinning church" (combining choices 1 and 2). Arnes Church has most of the time not had a pastor.

There are certain significant findings which the above comparisons bring into focus.

First, the youngest congregation in terms of membership tenure ( $75 \%$ have been members less than 20 years), whose members come mostly from a non-Adventist background (70\%), and which has had a ful1-time pastor for fifteen years, sees itself as being a warm, friendy, and soulwinning church.

Second, congregations whose majority of members have been Adventists more than twenty years (the average of $84 \%$ in the three remaining organized churches), who come predominantly from an Adventist background (averaging $74 \%$ ), and who have had a full-time pastor five years or less do not consider themselves to be soulwinning churches (on average only $5 \%$ of the members in the three remaining organized churches consider their churches to be soulwinning churches).

Third, it seems that the presence of a full-time pastor can make a significant difference in the 
soulwinning experiences of the Adventist churches in

Iceland.

\section{The Emphasis on Christian Education}

\section{Hlidardalsskoli's Contribution to \\ Church Growth}

A number of non-Adventist individuals have joined the SDA Church while attending Hlidardalsskoli. I am one of these. From time to time, however, church members have asked about the effectiveness of the secondary school in its contribution to church growth. This section presents certain statistical information relative to the contribution of the school to growth in the SDA Church in Iceland.

When one reads through the official church paper, Braedrabandid, covering the thirty-five years the school has been open, one is impressed by the frequency of articles emphasizing the importance of the schools in providing Adventist gouth with Christian education and in accomplishing church growth. Hlidardalsskoli has been promoted by conference leaders as the most successful instrument the church has for adding to its membership. The conference president, Erling B. Snorrason, writes:

The subject of schools has long had a predominant role in the church life and work of Seventh-day Adventists. Without the schools, our work here in this country would not be anywhere near what it is today. It is doubtful that any message of the church could have been 
stronger ${ }_{1}$ or more far-reaching, than the message of the schools.

In another article, Snorrason is even more

emphatic: "This work at Hlidardalsskoli is many times more 2

effective than any public meetings (opinber starfssemi) which, however, ought not to be neglected." This view is not supported by the survey. When asked what influenced them most in joining the church, the respondents ranked the influence of Hlidardalsskoli in the fourth place, together with SDA books and pamphlets and after parent, pastor, and public meetings. The church schools ranked seventh in the list of influential factors.

Table 7 (see appendix $C$ ) contains a numerical list representing all students who attended HIidardalsskoli from 1950 to 1982, a total of 1020 students. Of these, 241 came from an Adventist background (column 2), and 779 students from a non-Adventist background (column 3). For the purposes of this study, an individual was considered to be from an Adventist background when at least one of his/her parents was a practicing baptized Adventist at the time of his/her first gear at Hlidardalsskoli. A student who entered the school as a non-Adventist and was later

$1_{\text {Braedrabandid, February, 1983, p. } 2 .}$

2 Emphasis supplied:

3 Braedrabandid, November, 1981, p. 12.

${ }^{4}$ Two former principals, Gudmundur 01 afsson and Arni Holm, who are well acquainted with most active SDA church 
baptized into church fellowship was considered as having an Adventist background in his/her succeeding years of attendance.

of the 175 students who entered the school with an Adventist background and who were baptized during their years of attendance, 115 , or 66 percent, were still active church members in 1982. It would be reasonable to expect that many of the SDA youth would have been baptized anyway, even if they had not attended H1idardalsskoli. of the 779 students who entered the school as non-Adventists, 48 (6\%) were baptized into the SDA Church. Of these, 19 (40\%) were still active church members in 1982. Fifty of the 244 students from an Adventist background were not baptized during their years of attendance at Hlidardalsskoli.

The conference records show that during the first thirty-two years (1950-1982) that Hlidardalsskoli has been influencing non-Adventist students to join the church (a total of 48 , as mentioned above), there were 146 individuals who joined the church from non-Adventist background through other evangelistic programs. These

members in Iceland helped in the assessment of active members. We went through the entire list of students in attendance from 1950 to 1982 and evaluated, to the best of our knowledge, each name.

1 For the purpose of this study, an individual was considered as active if he/she attended church at least occasionally at the time this study was made. 
individuals never attended Hlidardalsskoli (see table 8 in appendix C)

The average length of stay at the school by students with an Adventist background is 2.6 years (see table 9 in appendix C). On the other hand, the average duration of stay of students with a non-Adventist 1

background is 1.5 years (see table 10 in appendix C). It is obvious that the turn-over of non-Adventist students at the school is rapid, and their brief stay makes it difficult to create a sense of continuity among the students and to maintain traditions and spiritual atmosphere in the school.

\section{Financial Costs}

As has been shown above, the conference leadership has consistently maintained that operating HIidardalsskoli is the best course to pursue in order to achieve church growth. This conviction has been emphasized by the heavy financial subsidies and appropriations granted the school by the conference through the years.

The funds needed to meet the net operating loss of HIidardalsskoli in 1982 could have covered five salaries, say, for new pastors and evangelists. It is reasonable to conclude that, in the absence of the financial losses incurred by the school, at least some of the annual

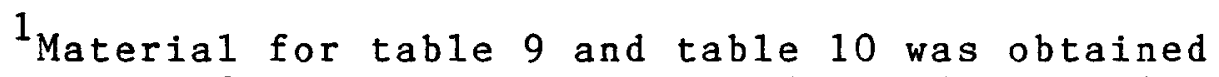
from Gudmundur 0lafsson, who collected the data while he was still a principal of the school. 
subsidies from the conference and the Northern European Division, as well as the donations from the members, could have been used to increase the ministerial force of the conference.

While these funds were being directed to the school to balance the books, the equivalent of 0.2 salary was devoted to evangelism in the conference during 1981, and the equivalent of 0.9 salary in 1982 .

With the low number of students in attendance at the school each year, it is not likely that the need for large subsidies and appropriations will diminish in the near future. Likewise, due to persistent financial losses incurred by the school each year, the conference will continue to have limited funds available for the hiring of additional ministers and evangelists.

It seems that the secondary school has absorbed energies, finances, attention, and other resources of the church at the expense of other, more direct, means of evangelism.

\section{In Retrospect}

It can be reasonably stated that since 1950 Christian education in general and H1idardalsskoli in particular have been considered, by the conference leaders, the most important means for outreach and church growth. Conference records reveal that as the attention 
to the school work increased, the work of evangelism elsewhere in the country decreased considerably.

The priority given to Christian education and the maintenance of educational institutions over other forms of evangelistic activities is understandable in the light of the fact that all the national conference presidents have been individuals whose main profession prior to assuming the leadership was teaching. As conference presidents, they did what they knew best to achieve church growth, that is, by emphasizing Christian education. Gudmundsson, the first national to serve as conference president, was trained as a teacher. Educational work and outreach through school work seem to have been his main burden as a church administrator. He directed the final preparations for and the construction of Hlidardalsskoli from 1949, leading to its opening in 1950, and served as its first principal for a decade while also being the conference president. This indicates his interest in the school and his belief in its potential for outreach.

Fewer than half of the SDA children of school-age living in the city of Reykjavik attend the one remaining Adventist church school. Increased tenure of the Adventist membership in Iceland indicates that there will be fewer young parents whose children could attend the schools. This factor powerfully affects the plans for Christian education in the SDA Church in Iceland and is 
reflected in the reduced number of Adventist youth attending H1idardalsskoli. The situation is paradoxical; a large majority ( 94 percent) of the church members favor keeping the schools open, but few parents send their children to the two schools that do remain open (see appendix A on excerpts from a school survey). This would indicate that the schools are not meeting the felt need. If parents question the quality of education being offered or are dissatisfied with the educational facilities, these issues must be dealt with and the necessary steps taken to win the confidence of the parents.

H1idardalsskoli apparently has contributed less to church growth than has been believed to be the case. Both Adventist and non-Adventist students in attendance have steadily decreased in number, and the Adventist/nonAdventist student ratio continues to be unfavorable to Adventist youth.

Follow-up of former students who have been baptized while attending Hlidardalsskoli has been negligible. The ministers, churches, and conference need to plan adequately to provide these students with the ministry and social fellowship they need.

${ }^{1}$ A11 seven individuals who have served as principals of Hlidardalsskoli were invited to express themselves regarding the effectiveness of the institution in terms of church growth. In their written replies they al1 were of the opinion that the school had contributed to the increase in membership of the church, but some expressed regret about the absence of follow-up ministry for students after they have left the school. 


\section{Church Members Express Their Interests}

Attached to the back of the survey was a page containing questions designed to survey the opinions of church members in five specific areas. No choices of answers were given (only blank lines for responses), and no leads or hints were offered. Participants were invited to express themselves freely, but briefly, about each subject. The list of questions and responses appear below. The figures represent the total number of responses from all the churches.

Questions

Responses

$\underline{\text { Tota1 }}$

1. What is most important to you in the church life?

Togetherness, friendship, open house, social activities.

Sabbath School

Prayer meetings, prayers

Other church meetings

Music, singing

Youth activities

Bible reading

Visits

Working for children

2. What do you think should be done more of, or better, in the church?

Togetherness, unity, expression of love, social activities. 
Questions

Responses

Tota 1

Work for children and youth.

Soulwinning work, public meetings.

Visiting among members, pastoral visits

Praying, prayer meetings.

More reverence in church meetings, better preparation for meetings.

Music

Publish books, pamphlets 2

Better Sabbath School $\quad 1$

Ingathering 1

Keep the lukewarm in the church

Health ministry

Church-school education

Less criticism

Do, more to keep good workers

3. What do you consider important which the conference is presently doing?

Publication of books, colporteur work

Public meetings, soulwinning work

Schools

Relief work, ingathering 
Questions

Responses

Tota1

Togetherness

Hlidardalsskoli

Work for children and youth

Bible Correspondence

School

Hiring of ministers

Church meetings

Getting foreign speakers

4. What do you consider of little use to which the conference presently devotes manpower and finance?

Hlidardalsskoli

Public meetings

Conference overhead

Publication of books

Farm at Hlidardalsskoli 1

Church school

The translation of too many articles in the church paper

The book and health food store

Foreign speakers

5. What should the conference be doing which it is presently not doing?

Public meetings, outreach work, soulwinning work 
Questions

Responses

$\underline{\text { Total }}$

More work for children

and youth

More health ministry

Train people for witnessing work

More music

Lay more emphasis on

H1idardalsskoli

More spiritual nurture

for church members

Publish Sabbath School

lessons for youth

Encourage more visitation

Have summer camps more frequent1y

Turn Hlidardalsskoli into a small church school

Establish day care center (skoladagheimili)

Increase democracy in the church

Get on television

Encourage church members to scatter themselves more around the country

Publish more pamphlets

A few individuals did not respond to any of the questions, and many addressed only some of them. Still, one is left with a clear impression of where the interests of Adventists in Iceland 1ie. 
The most valued ingredients of corporate church life (Question 1) is unity, friendship, and close fellowship ( 49 responses). This is further emphasized by the responses to the second question, "What do you think should be done more of, or better in the church?" which elicited thirty-five statements calling for even closer unity and togetherness.

The Sabbath School rates as the most popular of the regular church meetings ( 37 responses), with prayermeetings receiving a higher rating than other services, including divine services. However, when the scores given to the Sabbath School, prayer meetings, and other services are put together, sixty-four individuals consider church services (meetings) as most important in the church life. This is in harmony with the desire of the church members to experience unity and fellowship. The various church meetings provide one avenue for this experience.

Next on the list of needs and improvements desired, after greater unity and fellowship, is the need for increasing the work for children and youth in the church (15 responses). Furthermore, the church wants to see increased soulwinning work and visitation--by both members and pastors (14 responses each).

Among the projects presently being promoted by the conference, publishing work rates highest (21 responses; see Question 3), followed by public meetings and schools (13 responses each). When asked what the conference 
should be doing "which it is presently not doing?" (Question 5), respondents placed public meetings and related soulwinning activities at the top of the list ( 26 responses).

To the question, "What do gou consider of little use to which the conference presently devotes manpower and finance?" participants responded by placing Hlidardalsskoli at the top of the 1 ist ( 14 responses).

The responses to this last group of questions are in harmony with responses to other questions throughout the survey, and seem to indicate a widespread desire for unity, fellowship, and sharing. These characteristics make strong and healthy organizations; mutual trust, cheerfulness, and sharing of responsibility are honored traits (see appendix $F$ on characteristics of unhealthy and healthy organizations).

In general, Seventh-day Adventists in Iceland seem to be dissatisfied with their present role and performance in the outreach and soulwinning activities of the church. There is, however, a strong desire among them to be trained in witnessing activities. They seem to lack a sense of direction in their mission (see sample of a statement of mission and related material in appendix $D$ ). Given the proper training and opportunity for service in the mission of the church, the lay-people seem to contain a large reservoir of talents, gifts, and interest for mission that waits to be tapped. 


\author{
CHAPTER V \\ SUMMARY, CONCLUSIONS, AND \\ RECOMMENDATIONS
}

\title{
Summary and Conclusions
}

The purpose of this study has been to analyze the growth factors in the SDA Church in Iceland since 1950, with the intention of discovering how a more comprehensive planned program of evangelism could be recommended. After a brief historical sketch of the Icelandic nation, and a short history of the Seventh-day Adventist Church in Iceland, this section of the chapter summarizes the more significant findings of the study and presents the resultant conclusions.

For more than a millennium Icelanders have experienced hardship and adversity brought about by man and nature. In the formative period of the Vikings, armed struggles and bloody vengeance were frequent. Foreign oppression lasting more than six centuries was made doubly difficult by the frequent calamities caused by earthquakes and volcanic eruptions. 
Twice an official religion was forced upon the nation, first the Roman Catholic faith in the year 1000 , then the Lutheran faith in 1550. Surviving against great odds, the nation has emerged from its ordeal as a free, modern society, working hard for economic prosperity and material comfort.

Just about the time the Icelandic nation was gaining increased freedom and forming its own destiny, the Seventh-day Adventist Church obtained a foothold in the country. After a difficult beginning, caused mostly by internal conflict during the transition of leadership from David 0st1und to 0.J. 01sen, membership increased markedly from about 1915 to the late 1920s. Churches and companies were eventually organized in Keflavik (Sudurnes.), Hafnarfjordur, Regkjavik, Flateyri, Bolungarvik, Hnifsdal, Isafjordur, Skagastrond, Siglufjordur, Akureyri, Faskrudsfjordur, Vestmannaeyjar, Eyrarbakki, and Selfoss (Arnes).

For fifty-eight years (1897 to 1949 , and from 1968 to 1973) church leadership was in the hands of foreigners. Nationals have led the church for thirty gears, a period that coincides roughly with the church's experiment with an outreach program in which schools and education were given priority over other methods for promoting church growth.

The summary and conclusions brought out by the study are as follows: 


\section{Principles of Church Growth}

1. Healthy church growth usually takes place when church-growth principles are incorporated in a comprehensive strategy for evangelism, where a careful balance of all branches of the ministry is maintained.

2. To accomplish genuine growth the congregation should assign proper importance to the priesthood of all believers.

3. Church activities should be directed towards leading people to spiritual growth and eternal life.

4. No true growth is realized without the presence and guidance and power of the Holy Spirit.

5. Church growth in the New Testament sense calls for bold goals and thorough planning.

6. Seventh-day Adventists have adopted a holistic view of church growth. Their church-growth principles, when followed faithfully, are comprehensive enough to lead to vigorous growth.

\section{Early Evangelism in Iceland}

1. From about 1914 to 1928 the outreach plan followed by the SDA Church in Iceland emphasized evangelism through a program of vigorous visitation, Bible studies, and public meetings in many towns around the country. This evangelistic thrust was relatively successful as evidenced by the organization of eight churches and companies during this period. 
2. As ministers left behind newly established congregations to break ground in new places, the leadership of the mission apparently failed to provide the new churches with spiritual nurture and encouragement. One after another many of the early churches disintegrated in a relatively short time.

3. From 1906, when the Reykjavik Church was organized, until 1933, when the Akureyri Church was organized, a total of ten churches and companies were organized, seven of which had houses of worship. Eight of these congregations were later dissolved and five houses of worship were sold and not replaced.

Church Growth through Christian Education Administrative Direction

1. In 1928 two church schools were opened, this was the beginning of the school-approach to church growth. In time, there developed the general tendency to rely on Christian education as the major method of evangelism.

2. Once the shift toward Christian education began, no other comprehensive plan for church growth in Iceland Conference has existed.

3. As church leaders increasingly occupied themselves with matters of education, a corresponding decline in public evangelism resulted throughout the country. 
4. All three national conference presidents were individuals whose main profession was teaching prior to assuming leadership of the conference. This fact may have provided the stimulus that brought church growth through Christian education into prominence in Iceland Conference after 1950.

\section{Church Schools}

1. Survey findings show that the church schools in Iceland were ranked seventh among factors influencing people to join the church.

2. While the number of SDA schools and students who attend them steadily declines, the church members strongly favor Christian education. However, most Adventists (56\%) who favor Christian education do not have-children of school-age.

3. As the church schools in Vestmannaeyjar, Arnes, and Sudurnes are closed, the Reykjavik church school is the only SDA church school that remains open. More than half of the SDA parents in Reykjavik Church who have children of school-age send them to public schools.

4. This seems to indicate that parents are not satisfied with the quality of the school program presently being offered. 
The Secondary School

1. H1idardalsskoli was established primarily to meet the educational needs of SDA youth and to train missionary workers. However, church leaders soon began to consider the school as the chief instrument for achieving church growth. With the opening of the secondary school in 1950 , Christian education was effectively given priority emphasis in the outreach program of the church.

2. Contrary to common opinion among Adventists in Iceland, Hlidardalsskoli has not been the greatest contributor to church growth. According to the survey, the school tied for fourth place--together with SDA books and pamphlets.

3. The school-approach to church growth relies heavily on "prolonged schooling" of students. Hlidardalsskoli has not managed to keep its non-Adventist students longer than 1.5 years, on the average. This fact seems to have seriously affected the ability of the institution to contribute to church growth.

4. The church members in general, and the faculty of Hlidardalsskoli in particular have repeatedly expressed their serious concern about the negative influence exerted on the school by the majority of non-Adventists in attendance.

5. Follow-up of the more than 1000 former students has been negligible. 
6. Prospective students for Hlidardalsskoli that have Adventist background will number fewer than twenty in any given year in the foreseeable future.

7. The financial position of H1idardalsskoli is such that without heavy subsidies and appropriations from the conference and the Northern. European Division, annual grants from the governinent, and substantial donations from the church members, it cannot remain open.

\section{Evangelism in General}

1. SDA parents, pastors, and public evangelistic meetings were ranked by the survey respondents as the three most influential factors, respectively, in encouraging individuals to join the SDA Church.

2. There are indications that public evangelism could contribute more to church growth when properly prepared and supported by other branches of the ministry. Coordination among the various church programs for non-Adventists has been lacking. Long-term preparation and follow-up of interested persons from evangelistic campaigns, 5-day plans for smokers, summer camps, Pathfinders, Hlidardalsskoli, and Children's Storyhour have been deficient and sometimes neglected altogether.

3. There has been a tendency to discontinue programs that have been considered successful, i.e. Children's 
Storyhour, Vacation Bible School, Gift Bible Plan, and Pathfinder work for non-Adventist youth.

4. Church members do not seem to take advantage of the Bible Correspondence School as an aid in their outreach ministry.

5. The conference leadership has sought repeated by the help of guest evangelists to conduct evangelistic campaigns in Iceland--in the hope of boosting growth in membership. In terms of baptisms, the results have been meager.

6. The success of the 5-day plan for smokers, the popularity of SDA books among non-Adventists, and the warm response of the public to the annul Ingathering campaign indicate a receptive "climate" for further outreach by Adventists in Iceland.

7. Considerable interest among Adventists in Iceland for a greater emphasis on public evangelism and other soulwinning activities is now evident.

8. The majority of Icelandic Adventists (64\%) desire to be trained for witnessing work.

\section{Present State of the SDA \\ Church in Iceland}

1. The majority of present church members in Iceland Conference are second and third generation Adventists, and 74 percent have been members of the SDA Church eleven years or longer. 
2. Of the fourteen churches and companies that were organized from the beginning, only four remain as fully functional churches in 1984. No new church has been organized for the last thirty-two years.

3. The growth rate in the SDA Church declined from the annual average of 1.5 percent from 1964 to 1973 to the annual average of .7 percent from 1974 to 1983. By comparison, the rate of growth in the Pentecostal Church increased during this time from 1.1 percent to 1.8 percent.

4. According to government statistics, the Pentecostal Church surpassed the SDA Church in total membership in 1980. The SDA Church has dropped from being the second largest denomination in the 1940s to being the fourth largest in 1980 .

5. According to statistical reports for Iceland Conference, the average annual increase of church members from 1950 to 1980 is six. However, as records do not account adequately for apostatized, missing, and transferred members, growth could possibly be negative at present time.

6. Although the official membership figure in 1983 was 543 , the number of church-attending Adventists is, in the estimation of SDA ministers in Iceland, less than half this number. 
7. The longer an Adventist congregation in Iceland has had a fulltime pastor, the stronger is its sense of being a soulwinning church.

8. Vestmannaeyjar Church, whose membership tenure increases steadily due to the absence of new members, has not had a pastor for two decades.

9. Seventy-nine percent of Adventists have not given a Bible study to a non-Adventist during the previous twelve months; 8 percent believe they have had a part in bringing someone into church membership.

10. What the church members value most and desire more in the church life is the sense of unity, love, and fellowship.

11. Increased ministry for children and youth is one of the most keenly felt needs in Iceland Conference.

12. Adventists in Iceland desire more frequent visitation by their pastors.

13. The heavy financial support given to Hlidardalsskoli seriously limits the ability of the conference to hire new ministers.

\section{Prospects for Future Church Growth in Iceland}

1. With the expressed desire of Adventists in Iceland to be trained for active soulwinning work, the stage is set for improved church growth. 
2. The growth of other religious bodies in Iceland indicates that similar growth could be realized in the Adventist Church as well.

3. With strategic planning, bold goals, the dedication of church members and ministers, and the help of the Holy Spirit, the SDA Church in Iceland could double its membership within a decade.

\section{Recommendations}

\section{Introduction}

The outreach experience of the SDA Church in Iceland during the early part of the century was characterized by vigorous public evangelism throughout the country. However, it seems that the subsequent experiment of thirty-five years with the Christian education approach to church growth has actually reduced growth considerably.

Planning for a greater, consistent increase in church membership, it is logical to emphasize churchgrowth methods that give better results than others. This is not to say that the less productive methods should be ignored altogether but that priorities may have to be reordered.

It is recommended that the Iceland Conference adopt and implement a church-growth strategy that is likely to be more productive than what presently is being promoted. 
Successful church-growth principles, as well as findings brought out by the church survey and the past experience of the SDA Church in Iceland, suggest that the following items be included in any church-growth strategy to be implemented in the Iceland Conference.

\section{Programs and Strategies}

1. Adventist presence. There is presently an Adventist presence in the form of a church or a company in seven towns in Iceland. This is a 50 percent reduction from what used to be. Most Adventists are concentrated in, or near, the capital in the southwestern corner of the country. Existing SDA churches should endeavor to replant and multiply themselves.

It seems to be imperative that an Adventist presence be restored in each major geographical section of the country. Isafjordur, in the northwest; Egilsstadir, in the northeast; Hornafjordur, in the southeast, and Akranes and Stykkisholmur in the west are places that should be carefully considered for outreach endeavors. It is reasonable to expect that outreach plans include the reinstatement of a permanent gospel worker in the north at Akureyri in the near future.

2. Direct outreach. It is suggested that the implementation of outreach strategy be focused on 
"the local congregation as the primary center of action for church growth, nurture, outreach, planning, and the various ministries of the church."

3. Statement of mission. A statement of mission which adequately reflects the Great Commission and calls for the use of all the resources of the church, as well as the implementation of a balanced program of evangelism that includes all branches of the ministry should be formulated. Each congregation should be encouraged to formulate its own statement of mission (see samples in appendix $D$ ).

4. Implementation of a Mission Statement. A vital part of implementing the mission statement involves the provision of spiritual nurture for the members of the church. This applies equally to new and old members.

5. Suggestive outreach program. Adventists in Iceland have get to adopt a comprehensive strategy for evangelism based on the holistic view of church growth. They would do well to learn from others (i.e., Adventists in the Philippines) who are successfully engaged in a church-growth strategy-where the mobilization and training of lay-people is the key.

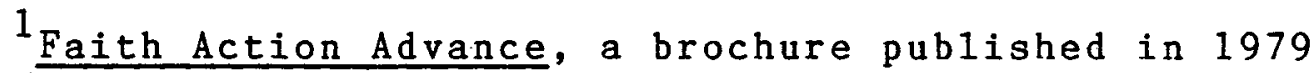
by the North American Division of Seventh-day Adventists (pages are unnumbered). 
Serious consideration should be given to the feasibility of conducting seminars which are likely to prove appealing to many among the public. First, various health seminars could be offered, i.e. on stress, nutrition, healthful living, and the Five-day Plan for smokers. Second, family seminars could follow (or even precede) the health seminars; these could include Marriage Commitment or Parent/Child Enrichment seminars. Finally, Bible study seminars, i.e., Daniel and Revelation, should be introduced. These could eventually lead to public evangelistic meetings as a crowning effort.

Each seminar needs to be connected to others so individuals attending one seminar can be invited to attend one or more of the others. This kind of program demands much diligence in visiting and maintaining personal contact with interested persons. Pastors and lay-people should endeavor to develop friendship with individuals showing an interest in the seminars.

An outreach program for the local church might be as follows:

$$
\begin{array}{ll}
\text { September } & \text { Local Ingathering campaign. } \\
\text { October } & - \text { Training seminar for lay-people } \\
& \text { for witnessing work. Five-day Plan } \\
& \text { for smokers is held. }
\end{array}
$$




$$
\begin{aligned}
& \text { Nov - Dec - Any one, or any combination, of } \\
& \text { health seminars are conducted (on } \\
& \text { stress, healthful living, } \\
& \text { nutrition). Also seminars on family } \\
& \text { life and marriage commitment can be } \\
& \text { held at this time. } \\
& \text { Jan - Feb - Seminars on the prophetic books of } \\
& \text { Daniel and Revelation could be held } \\
& \text { at this time. } \\
& \text { March - Apr - By this time the "field" may be } \\
& \text { ready for a series of public } \\
& \text { evangelism meetings. } \\
& \text { May - Sept - The minister and his church members } \\
& \text { who have been visiting interested } \\
& \text { persons all along continue their } \\
& \text { work of maintaining interest and } \\
& \text { giving Bible studies. } \\
& \text { June - July - Campmeeting, summer camp for } \\
& \text { children, pastor's vacation. }
\end{aligned}
$$
This suggestive program could be repeated annually. In order to reach people in towns where no Adventists live, the conference could consider sending selected individuals to these places to 
conduct some of the seminars mentioned above. When a group of people interested in the Advent message has been formed, the conference would be challenged to provide a permanent gospel worker to the area who could then serve several towns from a strategic location.

6. Spiritual gifts. The Holy Spirit gives to each person certain gifts and abilities that fit him/her to perform specific tasks and services. But whereas many individuals may not realize in which areas they are most gifted, they need to be aided in their discovery. The Spiritual Gifts Inventory (see appendix E) is a helpful instrument in accomplishing this. The local pastor should encourage the discovery and the exercise of spiritual gifts by the believers.

7. Equipping. The pastor should not be a do-it-a11 leader in the church. By equipping members of the congregation to minister to others, both inside and outside the church fellowship, the pastor not only shares the burden of inreach and outreach with fellow laborers but also increases the potential for church growth. Delegating responsibility to others in the ministry will lighten the work for the pastor. To accomplish this task, the pastor needs to help the church members to discover their own special call to 
service and then, through example, encouragement, and training, endeavor to equip them to respond effectively to this call.

8. Training of lay-people. Church leaders in Iceland would do well to take advantage of the active interest among the members of the church to be trained for witnessing. A training seminar could be held each year for lay-people who desire to be actively engaged in witnessing.

Immediately after the training seminar ends, the pastor, or any other experienced soulwinner, should give each trainee an opportunity to take part in a regular visitation program to give Bible studies. After a period of several weeks the trainee could take over the Bible studies and begin to train another lay-person.

9. Christian cell groups. In some countries the creation of Bible study groups, or Christian fellowship cells, outside the premises of a church building has proved to be of great help in boosting church growth. This has been evidenced by the impressive growth in the Bahai religion, which emphasizes its fireside groups. Many people who are prejudiced against entering a SDA church building may feel more comfortable attending a small study group in a home setting. Such groups frequently become the 
nuclei of new churches. The open homes and the warm hospitality of the Icelandic people should provide an ideal setting for Bible study groups.

10. Felt needs. Locating people receptive to the gospel is always an important concern. One of the better ways of locating receptive people is through the use of a survey questionnaire. Furthermore, every community has needs that call for attention. Frequent1y, meeting these needs opens up pathways of mutual understanding and trust. Feelings of loneliness, isolation in society, a search for meaning in life, and a desire for a sense of purpose in 1 ife are all felt needs that should be ministered to.

Marriage problems, youth problems, and the breaking up of families provide Christians with opportunities to minister to people in need. Sickness, accidents, tragedies, and sorrow present additional challenges for a meaningful ministry. There are other needs as well.

Each congregation should make a careful study of the felt needs in its community and endeavor to meet them. People whose felt needs are met by Seventh-day Adventists are likely to lend a sympathetic ear to the Adventist message. 
11. Visiting.

a. Regular church members. A strong, consistent visitation program must be considered a major pillar in any church-growth plan. The pastor is first of all a shepherd and, as such, should be in regular contact with all members of the congregation. At present, the Icelandic setting makes it feasible for the pastors to visit each church member at least once every three months. Special needs and circumstances call for more frequent visits.

b. Inactive and former Adventists. Church records indicate a large group of Adventists in Iceland who are either inactive as church members or have drifted away from the church. These individuals need to be ministered unto through a consistent visitation program. Pastors should receive training in visiting inactive members. Then they in turn could train lay-members to do the same. Attention given to inactive members of the church could prove to be a worthwhile ministry.

c. Former students of Hlidardalsskoli. More than 1,000 individuals have become familiar enough with the Adventist message to appreciate friendly visits from the church. This group of mostly young people may yet prove to be a fruitful field in terms of soulwinning. 
Some students who come from a non-Adventist background and join the church during their stay at Hlidardalsskoli return home to a climate that is less than favorable to their new-found faith. Understandably, some fall away because of such circumstances. The responsibility for keeping in close contact with these youth must ultimately rest with the local churches and the ministers. d. Other non-Adventists. A successful pastor and his church members endeavors to reach out to all individuals who are not Seventh-day Adventists. After all, the general public makes up the largest group of potential interests. By regular visits to non-Adventists, the pastor and his team workers can hope to build up a group of prospective candidates for membership in the SDA Church.

12. Advantages of a homogenous setting. The Icelandic society is relatively undifferentiated and homogenous itself with one culture, one language, and one race. In Iceland free education is available to all through university level, literacy is near 100 percent, and free socialized medicine is available to all citizens. One radio station and one television station serves all the people. It is a custom of courtesy to address others by first name. The 
Icelandic society is rather uniform and presents evangelists with few cultural or social barriers. In spite of this, the Icelandic society is not totally undifferentiated. There are differences of educational achievement, professional status, and those differences brought about by income.

Broadly speaking, the Adventist Church is coterminous with the broad middle class. In terms of the homogenous unit principle this means that Adventists should relate easily to the major sector of the Icelandic population.

This in itself should be of help in facilitating church growth, and church-growth strategists should capitalize on this. The open homes and the Icelandic hospitality extended to strangers and acquaintances alike further augment a church growth strategy that relies heavily on social interaction.

13. Changing priorities. Schools, both on the elementary and secondary level, have played a significant role in past decades in the SDA Church in Iceland, especially when Adventist youth was more numerous than presently is the case. The contributions of the schools to the strengthening of the church should be acknowledged.

However, circumstances have changed in recent years and only one elementary school remains open, 
and fewer than twenty prospective SDA students of secondary-school age can be anticipated in any given year in the foreseeable future.

In addition, more SDA parents are sending their children to public schools rather than SDA schools, indicating a need for improving the quality of education in the SDA schools.

Furthermore, the SDA membership in Iceland is aging. The majority does not have children of school-age. This will have a powerful affect on the operation and future of SDA schools in Iceland.

In the light of these considerations, it is recommended that a new church-growth strategy be adopted in the Iceland Conference which assigns a secondary role to Christian education in achieving church growth.

14. Goal setting. In matters of church growth, Adventists in Iceland are not accustomed to the setting of goals. Perhaps, the challenge presented by Charles Bradford applies here:

Let's stop kidding ourselves. Plans and programs that are not goal-oriented have no power to excite. We are made to be challenged. Goals give the future some form and shape. We have here the Biblical idea of hope--always looking ahead. This way we need feedback which one author calls 'the breakfast of champions.' 1

Charles E. Bradford, "The Need of Goals" Adventist Review, November 8,1984, p. 11 . 
Bradford further urges Seventh-day Adventists:

I make bold to say to the people of God... 'Get at it; do not delay.' The day of march has come. Assemble the people. Set goals. Be specific. Measure and number. Activate every force.

Any organization must be aware of the reasons for its existence and maintain certain goals and objectives, in order to be able to function properly. Robert $\mathbb{R}$. Greenleaf wrote:

The first thing an institution needs to do to start on a conspicuously higher course is to state clearly where it wants to go, whom it wants to serve, and how it expects those served directly as well as society at large, to benefit from the service. Unless these are clearly stated, an institution cannot approach its optimum performance. Yet, the internal administrators, left to themselves, usualiy hesitate to state goals so precisely.

On the importance of strategic planning and a close working relationship with God, Ellen G. White has aptly written:

God does not generally work miracles to advance His truth. . . God works according to great principles which He has presented to the human family, and it is our part to mature wise plans, and set in operation the means whereby God shall bring about certain results.

$1_{\text {Ibid. }}$

${ }^{2}$ Robert K. Greenleaf, Trustees as Servants

(Cambridge, Massachussets: Center for Applied Studies, $1975)$, p. 22

${ }^{3}$ E1len G. White, Evangelism (Washington, D.C.: Review and Herald Publishing Association, 1946), p. 653. 
She comments further:

Do all you can on your part to bring about favorable results. Jesus has ${ }_{4}$ promised divine aid, but not aside from human efforts.

Dedicated gospe1 workers may take courage from such divine promises and thus go forth with. boldness in compliance with the Great Commission. Applying these counsels to an outreach strategy in Iceland may lead to unprecedented growth in the SDA Church in the gears ahead.

\section{Evaluations}

1. Self-assessment. Periodic evaluation of the outreach program and its effectiveness is an important aspect of any church-growth strategy. Looking back to see what progress has been made in every area of growth enables one to profit from past experience and to make the necessary corrections for greater progress.

2. Church survey. From time to time, perhaps every five jears, the church should obtain valuable information about itself, its progress, and its needs by repeating the surveg.

3. Survey of inactive church members. Church leaders may find it a rewarding experience to survey inactive church members. In Iceland it is not difficult to locate individuals with the help of the national registry

\footnotetext{
Review and Herald, February 3, 1885.
} 
(Thjodskrain). Perhaps, some individuals could be helped to return to active participation in church life.

4. Public survey. It could be a worthwile project for selected individuals to conduct a survey among the public to obtain information about what non-Adventists think about the SDA Church and its activities. By repeating this periodically, the church may be better able to build up and maintain a favorable public image of the SDA Church.

\section{Projections}

It is reasonable to expect ministers of the gospel to show forth some fruit for their labors. While ministers should be free from unreasonable demands and expectations, they should, nevertheless, be able in many cases to measure the results of their work. The following hypothetical sample may serve to illustrate what growth in membership could take place in the Seventh-day Adventist Church in Iceland.

Five ful1-time ministers (see fig. 7), each supported and assisted by an enthusiastic group of adequately trained lay-people, and each bringing five individuals into church fellowship from non-Adventist background, would have a total of twenty-five new converts in one year. After five years, during each of which this would be repeated, a gross total of 125 new church members would have been added. 


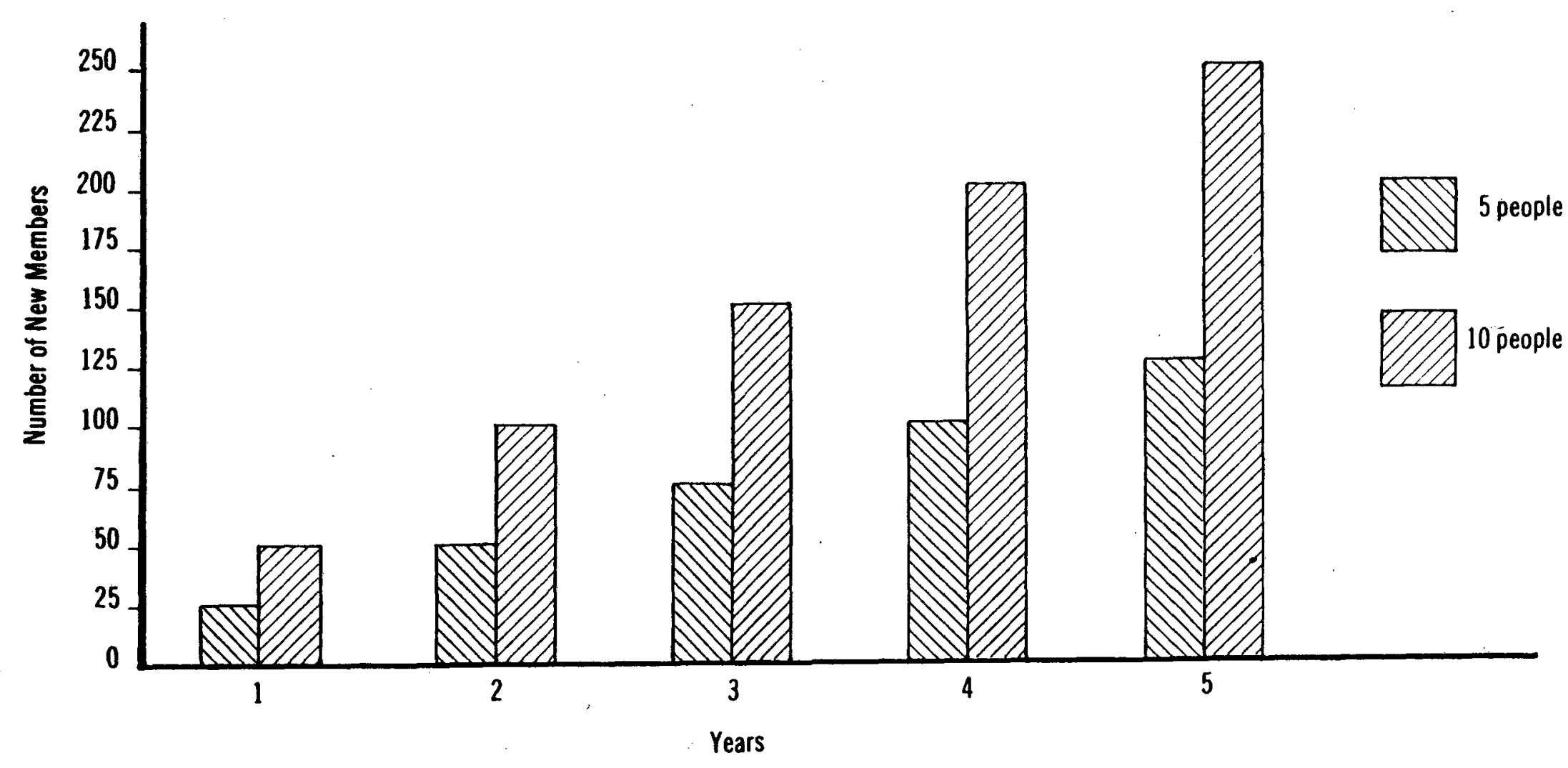

If each of 5 ministers baptizes 5 individuals from a non - Adventist background each year, 25 new members would be added each year, or a total of 125 over a 5 - year period.

If, however, each minister baptized 10 individuals each year, the increase in 5 years would total 250 new members, which is more than presently are attending church regularly.

Fig. 7. Projected Church Growth 
193

If, however, the annual average number of baptisms expected from each team could be increased to ten, the total after five years would be 250 new church members. Such increase would in only five years double the present number of church-attending Adventists!

This is a conservative projection and is

attainable. By reordering priorities and by rallying the enthusiastic support and involvement of the members of the church, the Seventh-day Adventist church in Iceland should be able to enter a new era of unprecedented church growth. 


\section{APPENDIX A}

\section{SURVEYS}

1. SDA Church Survey Questionnaire (in Icelandic)

2. English translation of SDA Church Survey Questionnaire

3. TABLE 6: Compilation of Data from SDA Church Survey

4. Translated Excerpts and Data from SDA School Survey 
1. Settu hring um pá tölu sem sýnir hve lengi pú hefur verio skirour meolimur safnadarins.

1. Skemur en 1 ár.

2. 1 til 5 ár.

3. 6 til 10 ár.

4. 11 til 20 ár.

5. 21 ár, eda lengur.

2. Var a.m.k. annad foreldri pitt abventisti einhvers hluta fyrstu 12 ára ævi pinnar? Já Nei

3. Settu hring um pá tölu sem best sýnir paó samfélag, sem pú telur big hafa vio Jesú núna.

$\begin{array}{crrrrr}\text { Ekkert } & & & & \text { Náio } \\ 1 & 2 & 3 & 4 & 5\end{array}$

4. Telur pú pig hafa frio vio Gus?

Já Nei

5. Ao hve miklu leyti hefur pú stundao nám i skólum safnabarins?

Aldrei $1-3$ ár $4-6$ ár Meira
A. Barnaskóla
B. Eftir barnaskóla
c. Menntaskóla
D. Háskóla

6. Hve mikla áherzlu telur pú ao safnadarprestur pinn leggi à sálnavinnandi starf?

Enga àherzlu

$$
12
$$

of litil

àherzla

1
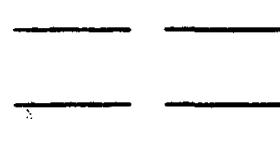

7. hvao finnst pér un pá áherzlu sem samtỏkin leggja á opinberar samkomur?

8. Hversu vel telur pú big undir pao búin(n) ao taka pátt i sálnavinnandi starfi?
Alls ekkert
Mjög vel

$\begin{array}{lllll}1 & 2 & 3 & 4 & 5\end{array}$

9. Oskar pú eftir pví ao taka pátt i leiobeininganámskeioi i sálnavinnandi starfi? 
10. Hefur pú sótt námskeio i vitnisburoarstarfi s.1. 10 ár?

11. Hefur pú tekio virkan pátt i sálnayinnandi starfi s.l. 12 mánuơi?

12. Gegnir pú einhverri ábyrgóarstōou $i$ söfnuóinum núna?

13. Settir pú pér persónulegt takmark i sálnavinnandi starfi á yfirstandandi ári?

14. Hefur pú s.1. 12 mánuói unnio/aóstodaó i

$\begin{array}{lcc}\text { Systrafélagsstarfinu } & \text { Já } & \text { Nei } \\ \text { Fimm daga áforminu } & \text { Já } & \text { Nei } \\ \text { Innsōfnun } & \text { Já } & \text { Nei }\end{array}$

15. Hefur pú rannsakao Biblíuna meo utansafnabarfólki síbast lióna 12 mán.

16. Ao hve miklu leyti ertu sammála eftirfarandi yfirlýsingum.

$\begin{array}{cc}\text { Mjōg } & \text { Mjōg } \\ \text { ósammála } & \text { sammála }\end{array}$

A. Nánustu fjölskyldumeblimir minir styrkja samfélag mitt vio Jesú.

B. Hvildardagsskólinn okkar er pannig aó ég hika ekki vió aó bjóóa utansafnaóargestum ao koma

$\begin{array}{lllll}1 & 2 & 3 & 4 & 5\end{array}$

C. Flestar prédikanir á guóspjónustum okkar eru áhugavekjandi.

$\begin{array}{lllll}1 & 2 & 3 & 4 & 5\end{array}$

D. Opinbert starf hefur yfirleitt borio góoan árangur i sōfnuoi okkar

E. Einstaklingar sem sameinast sö́fnuoinum eftir opinberar samkomur eru yfirleitt ekki lengi í söfnuoinum.

F. Eg à auovelt meo ao vitna um trú mína

G. Söfnuour minn nýtur mikils álits á mebal almennings 
17. Hve marga einstaklinga, utan pinnar eigin fjolskyldu, hefur pú, ao einhverju eba ollu leyti átt pátt í ao leióa inn 1 söfnuoinn s.1. 3 ár?

1. ókunnugt um paó

2. einn

3. tvo til fimm

4. sex til tiu

5. meira en tíu

18. Hvada svar lýsir best reynslu pinni

nủa $i$ eftirfarandi yfirlýsingum?

A
ekki vio Aldrei stundum leitt Alltaf

A. Eg les daglega í Biblíunni

B. Eg bio daglega fyrir endurfæoingu einstaklings meo nafni

C. Ég les 1 bókim Anda spádómsins

D. Eg saki banasamkomur safrabarins

E. Eg sæki bænasamkomur 1 heimahúsi

F. Eg hjálpa nágrönnum mínum meo persónuleg vandamál beirra

G. Eg tek daglega pátt i fjölskyldubænastundum

H. Eg vitna fyrix oorum 1 daglegum störfum minum

I. Eg sæki hvildardagsskólann reglulega

J. Eg saki guosbjónustur reglulega

K. Ég reyni markvisst ao leioa utansafnadarzttingja til Krists

19. Hvao telur pú aó velmetinn safnabarprestur eigi ao vera mörg ár staosettur 1 sama söfnuoi?

$\sim_{1-3}$ ár 4-7 ár 8-10 ár meira 
20. Settu hring um pá tölu sem lýsir sōfnuoi pinum best.

A. Er ekki sálnavinnandi söfnuour

$$
12
$$

B. Meginreglur safnadarins eru ekki i hávegum hafoar

1 2

3 4

c. Sofnuour minn er kaldur og fráhrindandi gagnvart gestum og ókunnugum

Er öflugur sálnavinnandi söfnuour

4 5

Meginreglur safnabarins eru i hávegum hafóar

D. Söfnuour minn er kaldur og fráhrindandi gagnvart nýjum meólimum, hvao snertir pátttoku i starfi safnabarins

12

E. Nýir meolimir eru vanraktir

1 2

F. Unga fólkio er vanrakt.

1

2

G. Mér finnst ég ekki eiga heima $i$ sôfnuoinum

21. Attu nána vini sem eru ekki sjounda dags abventistar?

22. Hvert sakja börnin bín skóla núna?

1. Safnabarskóla

2. Ríkisskóla

3. Ég á engin bōrn á skólaaldri
3

4 3

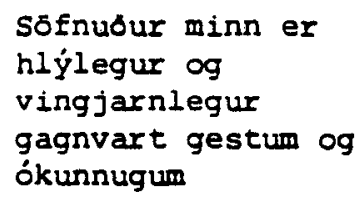

4

5

Unga fólkio far tækifari til virkrar páttöku i safnabarlífinu

\section{5}

Eg finn hve velkomin(n) ég er $i$ sōfnuóinum

3

4

5

Enga Fáeina Marga 
23. Faróu heimsóknir frá safnaóarpresti?

24. Eg tel ab:
a) aldrabir fái nægar heimsóknir
b) unga fólkió fái nægar heimsóknir
c) ab söfnuourinn yfirleitt fái nagar heimsóknir

25. Huaóa aldurshópi tilheyrir pú?

26. Kyn?

27. Hver er hjúskaparstaba bín núna?

28. AO hve miklu leyti lestu

Bræórabandis?

29. Ao hve miklu leyti lestu Innsýn?

30. Ao hve miklu leyti lestu hvildardagsskólalexiurnar

31. Hve oft hefur pú áhuga á ab prédikarar frá öorum sōfnuoum okkar prédiki i sōfnuoi pínum?
Aldrei sjaldan oft

$\begin{array}{ll}\text { Já } & \text { Nei } \\ \text { Já } & \text { Nei } \\ \text { Já } & \text { Nei }\end{array}$

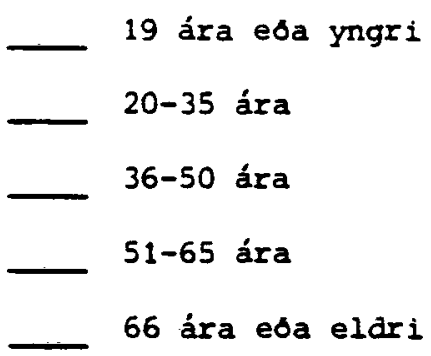

$\operatorname{kar} 1$ kona

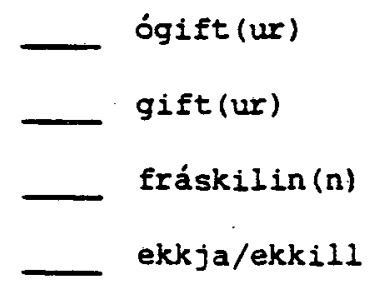

Ekkert

Allt

$\begin{array}{lllll}1 & 2 & 3 & 4 & 5\end{array}$

$\begin{array}{lllll}1 & 2 & 3 & 4 & 5\end{array}$

$\begin{array}{lllll}1 & 2 & 3 & 4 & 5\end{array}$

Tvisvar Einu sinni Annan hvern Arsfjóroi mánuói i mánuói mánuó ungslega 
32. Gefou til kynna ao hve miklu leyti eftirfarandi adilar, eoa atrioi höfou àhrif á pig til ákvörounar um aó sameinast sōfnuónum.

$\begin{array}{lllll}\text { A ekki } & \text { Engin } & \text { Einhver } & \text { Talsvero } & \text { Mikil } \\ \text { vio } & \text { áhrif } & \text { ăhrif } & \text { áhrif } & \text { áhrif }\end{array}$

Safnabarprestur

Bóksali

Foreldri, sem var safnabarmeolimur

Annar attingi i sōfnuoinum

Safnabarmedlimur sem ég pekkti vel

Nágranni sem var safnadarmeolimur

Vinnufélagi sem var safnaobrmeol.

Bakur eba rit safnabarins

Systrafélag1o

Bibliubréfaskólinn

Biblfurannsóknir á heimili pinu

Opinberar samkomur

Innsöfnunarheimsókn

Barnaskóli safnaóarins

Hlíbardalsskóli

Fimm daga áformio

Annas: Bver/Hvab?

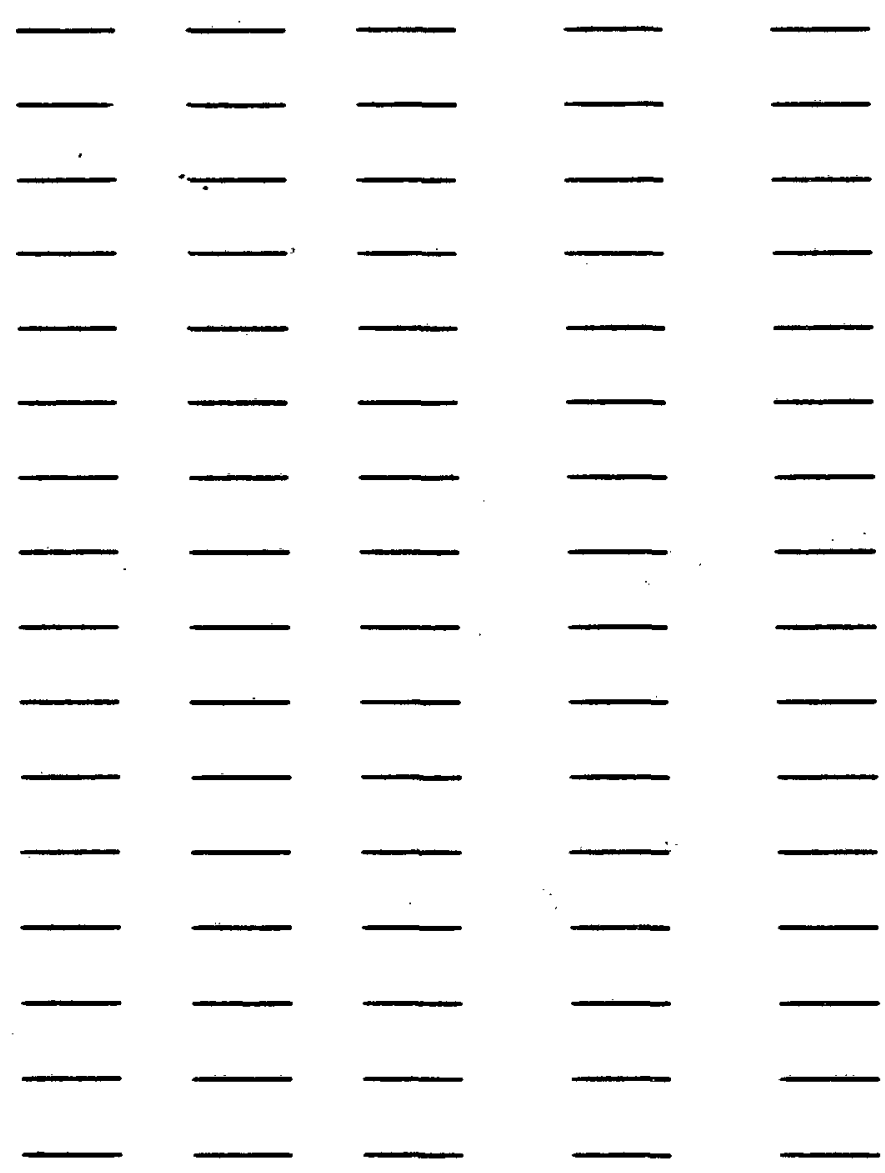


33. Hvaঠ er bér kærast eठa mikilvægast $i$ safnadarlifinu?

34. Evaó telur pú ao megi gera betur i söfnuoinum?

35. Hvao af pví sem Samtökin gera telur pú mikilvagt?

36. Hvao af bví sem Samtökin leggja starfskrafta og fjármuni i telur pú ab komi aó litlu gagni?

37. Hvaó telur pú ao Samtökin attu aó gera sem pau gera ekki núna?

38. Eg sæki kirkju 1:

Reykjavik

Vestmannaeyjar

Suóurnes'

Arnessōfnuour

sōfnuói areifora 
CHURCH SURVEY

1. CIRCLE THE NUMBER SHOWING HOW LONG YOU HAVE BEEN A BAPTIZED ADVENTIST.
1. LESS THAN 1 YEAR

2. 1 - 5 YEARS

3. 6 - 10 YEARS

4. $11-20$ YEARS

5. OVER 20 YEARS

2. WAS AT LEAST ONE OF YOUR

PARENTS AN ADVENTIST SOMETIME

DURING THE FIRST 12 YEARS OF

YOUR LIFE?

YES

No

3. CIRCLE THE NUMBER INDICATING

THE RELATIONSHIP THAT YOU

HAVE WITH JESUS CHRIST

NONE

$\begin{array}{lllll}1 & 2 & 3 & 4 & 5\end{array}$

4. DO YOU CONDSIDER YOURSELF

HAVING PEACE WITH GOD?

YES

NO

5. TO WHAT EXTENT HAVE YOU ATTENDED ADVENTIST SCHOOLS?
A) ELEMENTARY (GRADES 1-6)
B) POST-ELEMENTARY (GRADES 7-10).
C) ADVANCED SCHOOLING (GRADES 11-14)
D) UNIVERSITY (BEYOND GRADE 14)

NEVER 1-3 YRS 4-6 YRS LONGER

6. CIRCLE THE NUMBER WHICH SHOWS

THE EMPHASIS YOUR PASTOR PLACES

ON SOULWINNING.

LITTLE IMPORTANCE

$$
12
$$

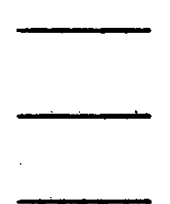

7. HOW DO YOU FEEL ABOUT THE AMOUNT

OF EMPHASIS THE CONFERENCE LAYS

ON EVANGELISM?

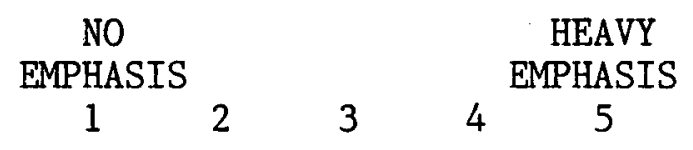

8. HOW WELL PREPARED ARE YOU

FOR THE WORK OF SOULWINNING?

NOT AT ALL

1

2

VERY WELL

9. DO YOU DESIRE TO PARTICIPATE

IN A TRAINING SEMINAR FOR

EVANGELISM?

YES

NO 
10. WITHIN THE LAST 10 YEARS

HAVE YOU ATTENDED A

WITNESSING TRAINING PROGRAM?

YES

NO

11. HAVE YOU BEEN ACTIVELY ENGAGED

IN SOULWINNING WORK DURING THE

PAST 12 MONTHS?

YES

NO

12. DO YOU PRESENTLY HOLD A POSITION

OF RESPONSIBILITY IN THE CHURCH?

YES

NO

13. DID YOU SET YOURSELF A PERSONAL SOULWINNING GOAL THIS YEAR?

YES

NO

14. HAVE YOU DURING THE LAST 12

MONTHS BEEN INVOLVED IN

DORCAS

FIVE-DAY PLAN

INGATHERING

YES

NO

YES

NO

YES

No

15. HAVE YOU HELD BIBLE STUDIES

WITH NON-ADVENTISTS DURING

THE PAST 12 MONTHS?

YES

No

16. HOW MUCH DO YOU AGREE WITH THESE STATEMENTS?

A) MY IMMEDITE FAMILY MEMBERS

HELP MY RELATIONSHIP WITH

CHRIST.

$\begin{array}{lllll}1 & 2 & 3 & 4 & 5\end{array}$

B) I WOULD FEEL COMFORTABLE

BRINGING A VISITOR TO OUR

SABBATH SCHOOL.

$\begin{array}{lllll}1 & 2 & 3 & 4 & 5\end{array}$

C) MOST SABBATH SERMONS ARE

INTERESTING.

1

2

3

4

5

D) PUBLIC EVANGELISM HAS

GENERALLY BEEN SUCCESSFUL IN OUR CHURCH.

$\begin{array}{lllll}1 & 2 & 3 & 4 & 5\end{array}$

E) INDIVIDUALS WHO JOIN THE CHURCH AFTER EVANGELISTIC MEETINGS USUALLY DO NOT REMAIN LONG IN THE CHURCH.

$\begin{array}{lllll}1 & 2 & 3 & 4 & 5\end{array}$


F) I CAN EASILY SPEAK ABOUT MY FAITH.

G) PEOPLE IN OUR COMMUNITY HAVE A HIGH OPINION OF OUR CHURCH.

17. HOW MANY PEOPLE HAVE YOU BEEN WHOLLY OR PARTIALLY RESPONSIBLE FOR BRINGING INTO THE CHURCH IN THE LAST THREE YEARS?
DISAGREE

STRONGLY
1

1

$\begin{array}{lll}3 & 4 & 5\end{array}$

1. UNAWARE OF ANY

2. ONE

3. TWO TO FIVE

4. SIX TO TEN

5. MORE THAN TEN

18. WHICH ANSWER BEST DESCRIBES YOUR EXPERIENCE?

A) I READ MY BIBLE DAILY

B) I PRAY DAILY FOR THE CONVERSION OF AN INDIVIDUAL BY NAME.

C) I READ IN THE BOORS OF THE SPIRIT OF PROPHECY.

D) I ATTEND THE PRAYERMEETINGS IN THE CHURCH.

E) I ATTEND PRAYER MEETINGS IN A HOME SETTING.

F) I HELP MY NEIGHBORS WITH THEIR PERSONAL PROBLEMS.

G) I PARTICIPATE DAILY IN FAMILY WORSHIP.

H) I WITNESS TO OTHERS IN MY DAILY WORK.

I) I ATTEND SABBATH SCHOOL REGULARLY.

J) I ATTEND DIVINE SERVICES REGULARLY.

R) I CONSISTENTLY ENDEAVOR TO LEAD MY NON-ADVENTIST RELATIVES TO CHRIST.

\section{DOESN'T NEVER SOME- USUALLY ALWAYS} APPLY 
19. HOW LONG DO YOU THINK A GOOD PASTOR SHOULD SERVE THE SAME CHURCH?

20. CIRCLE THE NUMBER WHICH BEST DESCRIBES YOUR CONGREGATION.
A) IS NOT A SOULWINNING CHURCH 1

B) THE PRINCIPLES OF THE CHURCH ARE NOT HONORED. 1

C) MY CHURCH IS COLD AND UNFRIENDLY TO STRANGERS

$$
1
$$

2

D) MY CHURCH IS COLD AND UNFRIENDLY TO NEW MEMBERS 1

E) NEW MEMBERS ARE NEGLECTED

1 2

F) YOUNG PEOPLE ARE NEGLECTED

12

G) I DON'T FEEL AT HOME IN THE $\mathrm{CHURCH}$ 1 2

21. DO YOU HAVE CLOSE FRIENDS WHO ARE NOT SEVENTH-DAY ADVENTISTS?

22. WHERE DO YOUR CHILDREN PRESENTLY ATTEND SCHOOL? 3

3

1-3 YRS. 4-7 YRS. 8-10 YRS. LONGER

4 IS A POWERFUL SOULWINNING

THE PRINCIPLES OF THE CHURCH ARE HONORED.

4 5 MY CHURCH IS WARM AND FRIENDLY TO STRANGERS 45 MY CHURCH IS WARM AND FRIENDLY TO NEW MEMBERS. 4 5

NEW MEMBERS ARE IMMEDIATELY ACTIVATED IN THE CHURCH LIFE. 4 5

YOUNG PEOPLE ARE GIVEN OPPORTUNITIES TO PARTICIPATE ACTIVELY 4 5

I SENSE HOW WELCOME I AM IN THE CHURCH 5

NONE

A FEW MANY

1. CHURCH SCHOOL

2. PUBLIC SCHOOL

3. I HAVE NO CHILDREN OF SCHOOL-AGE 
23. ARE YOU VISTED BY THE PASTOR?

OFTEN

SELDOM

NEVER

24. I AM OF THE OPINION THAT
A) THE OLD PEOPLE ARE VISITED
FREQUENTLY ENOUGH
B) THE YOUNG PEOPLE ARE VISITED FREQUENTLY ENOUGH
C) THE CHURCH IN GENERAL IS
VISITED FREQUENTLY ENOUGH

YES

NO

YES

No

YES

NO

25. WHAT IS YOUR AGE GROUP?

1. 19 YEARS OR YOUNGER

2. 20 - 35 YEARS

3. 36 - 50 YEARS

4. 51 - 65 YEARS

5. 66 YEARS OR OLDER

26. YOUR SEX

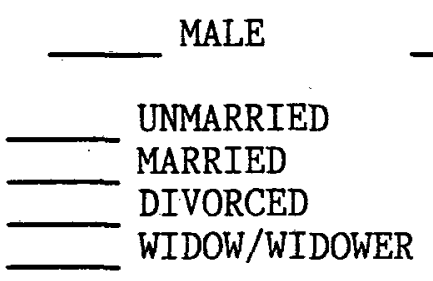

FEMALE

27. WHAT IS YOUR MARITAL STATUS?

28. HOW MUCH DO YOU READ OF BRAEDRABANDID (CHURCH PAPER)?

NOTHING

1

2

3

4

ALL 5

29. HOW MUCH DO YOU READ OF INNSYN (YOUTH PAPER)?

1

2

3

4

5

30. HOW MUCH DO YOU READ OF THE SABBATH SCHOOL LESSONS?

1

2

3

4

5

31. HOW FREQUENTLY DO YOU WISH TO HAVE PREACHERS FROM OTHER CHURCHES PREACH IN YOUR CHURCH?

TWICE A ONCE

MONTH MONTHLY BIMONTHLY QUARTERLY 
32. INDICATE HOW MUCH OF AN INFLUENCE EACH SOURCE LISTED BELOW WAS TOWARD YOUR JOINING THE ADVENTIST CHURCH.

$$
\begin{array}{ccccc}
\text { DOES NOT } & \text { NO } & \text { SOME } & \text { CONSIDERABLE } & \text { GREAT } \\
\text { APPLY } & \text { INFLUENCE } & \text { INFLUENCE } & \text { INFLUENCE } & \text { INFLUENCE }
\end{array}
$$

PASTOR

COLPORTEUR

SDA PARENT

ANOTHER SDA

RELATIVE

CHURCH MEMBER

I KNEW WELL

SDA NEIGHBOR

SDA WORR COMPANION

SDA BOOKS,

PAMPHLETS

DORCAS

BIBLE CORRESPONDENCE SCHOOL

BIBLE STUDIES

AT HOME

PUBLIC MEETINGS

INGATHERING VISIT

CHURCH SCHOOL

HLIDARDALSSKOLI

FIVE-DAY PLAN
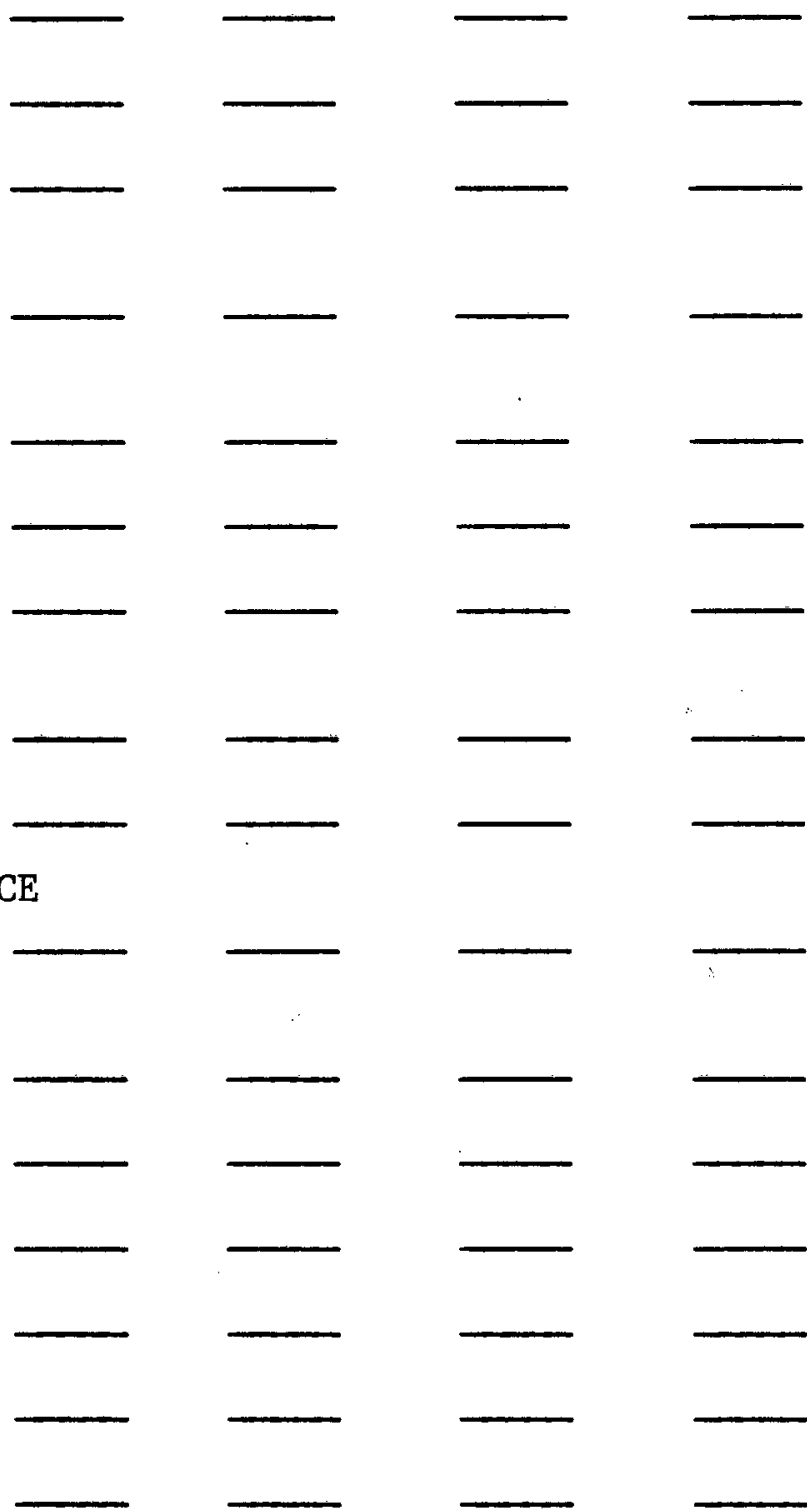

OTHER

33. WHAT IS MOST IMPORTANT TO YOU IN THE CHURCH LIFE?

34. WHAT DO YOU THINR SHOULD BE DONE MORE OF, OR BETTER IN THE CHURCH? 
35. WHAT DO YOU CONSIDER IMPORTANT

WHICH THE CONFERENCE IS

PRESENTLY DOING?

36. WHAT DO YOU CONSIDER OF

LITTLE USE TO WHICH THE

CONFERENCE PRESENTLY DEVOTES

MANPOWER AND FINANCE?

37. WHAT SHOULD THE CONFERENCE

BE DOING WHICH IT IS PRESENTLY

NOT DOING?

38. I ATTEND CHURCH IN

REYKJAVIK CHURCH

VESTMANNAEYJAR CHURCH

SUDURNES CHURCH

ARNES CHURCH

CONFERENCE CHURCH 
COMPILATION OF DATA FROM CHURCH SURVEY

(Norms Based On 137 Members In Iceland Conference)

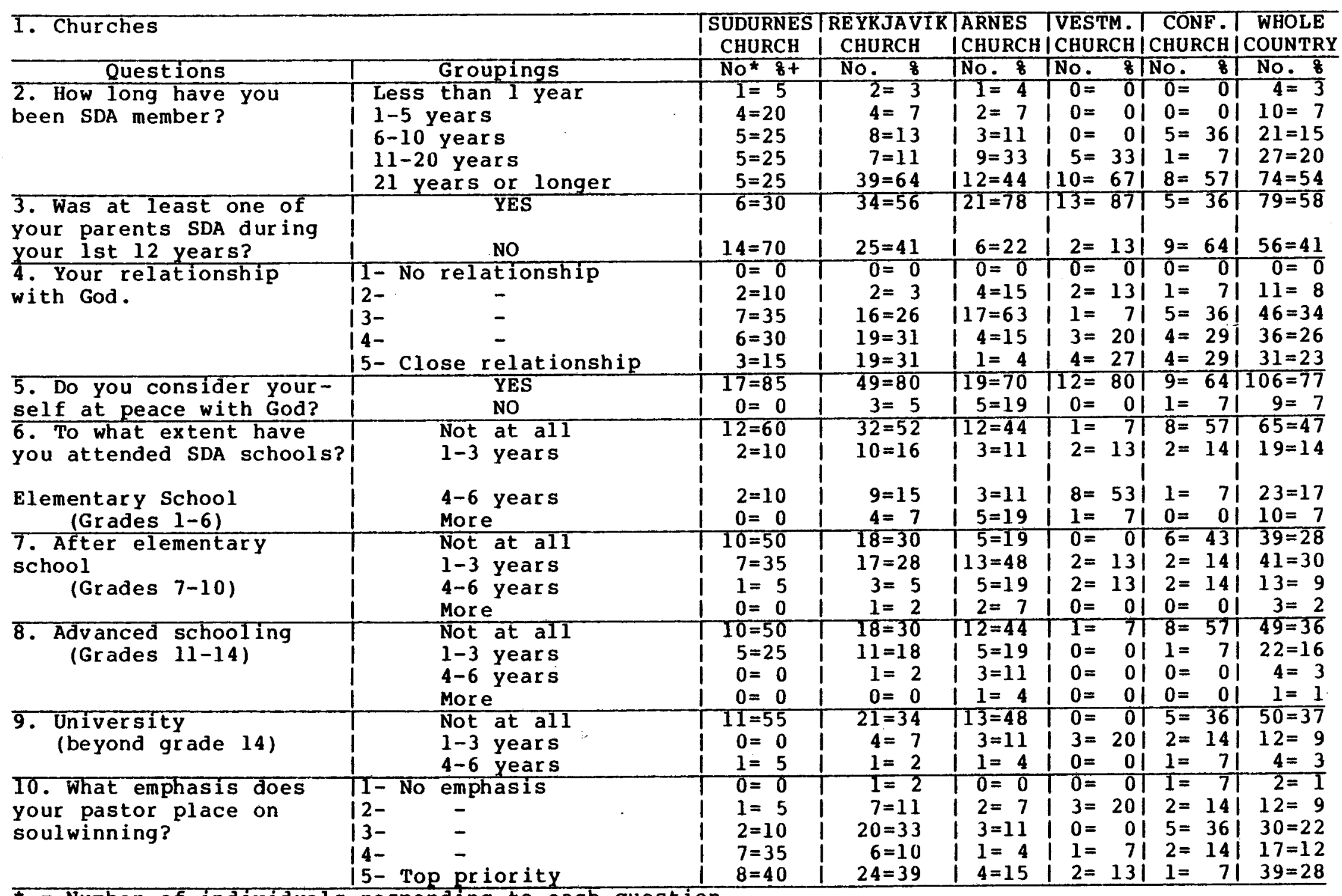

$\star$ = Number of individuals responding to each question.

$+=$ Percentage of individuals responding to each question. 


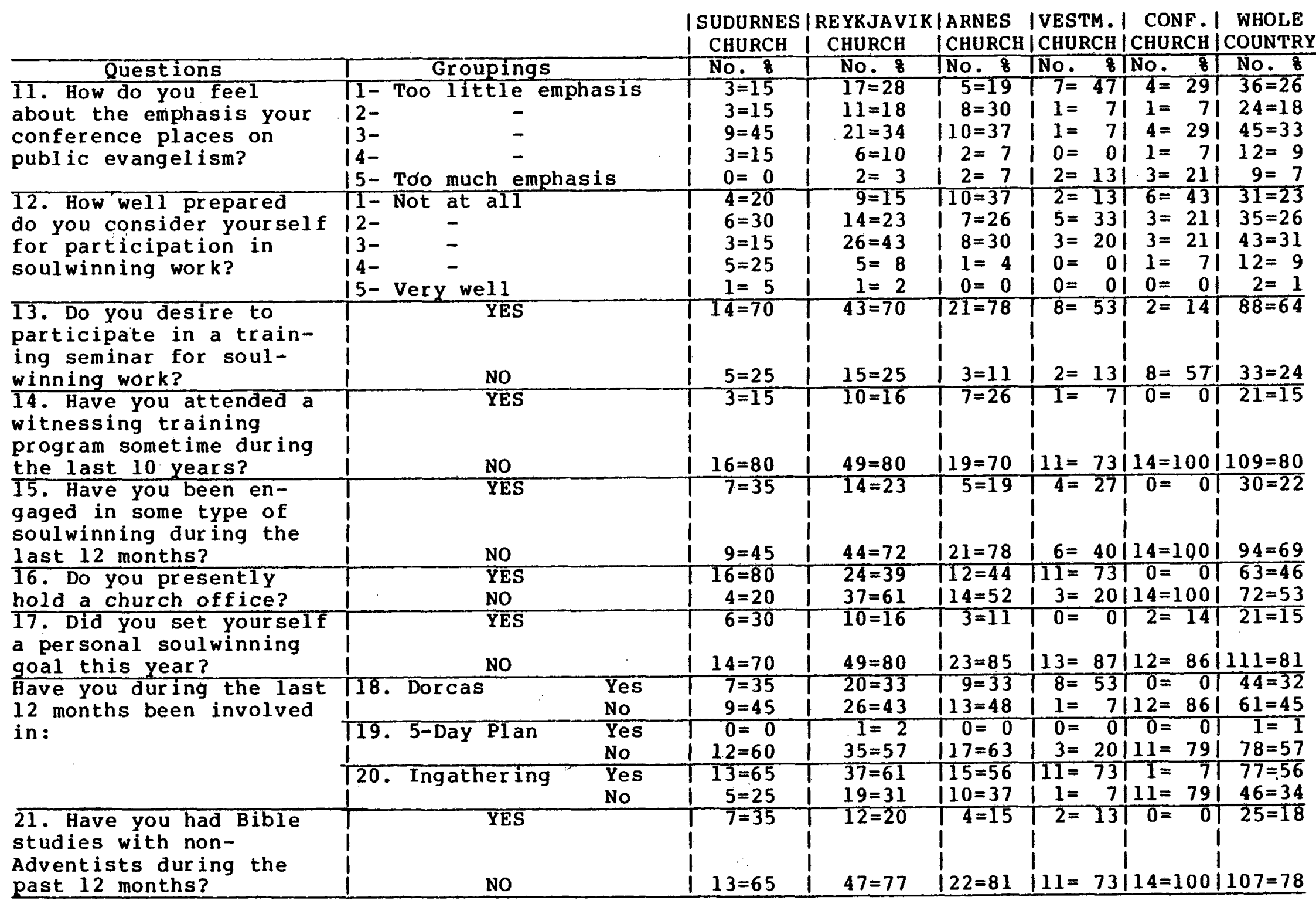


TABLE 6 Continued

| SUDURNES |REYKJAVIK|ARNES |VESTM. | CONF. | WHOLE

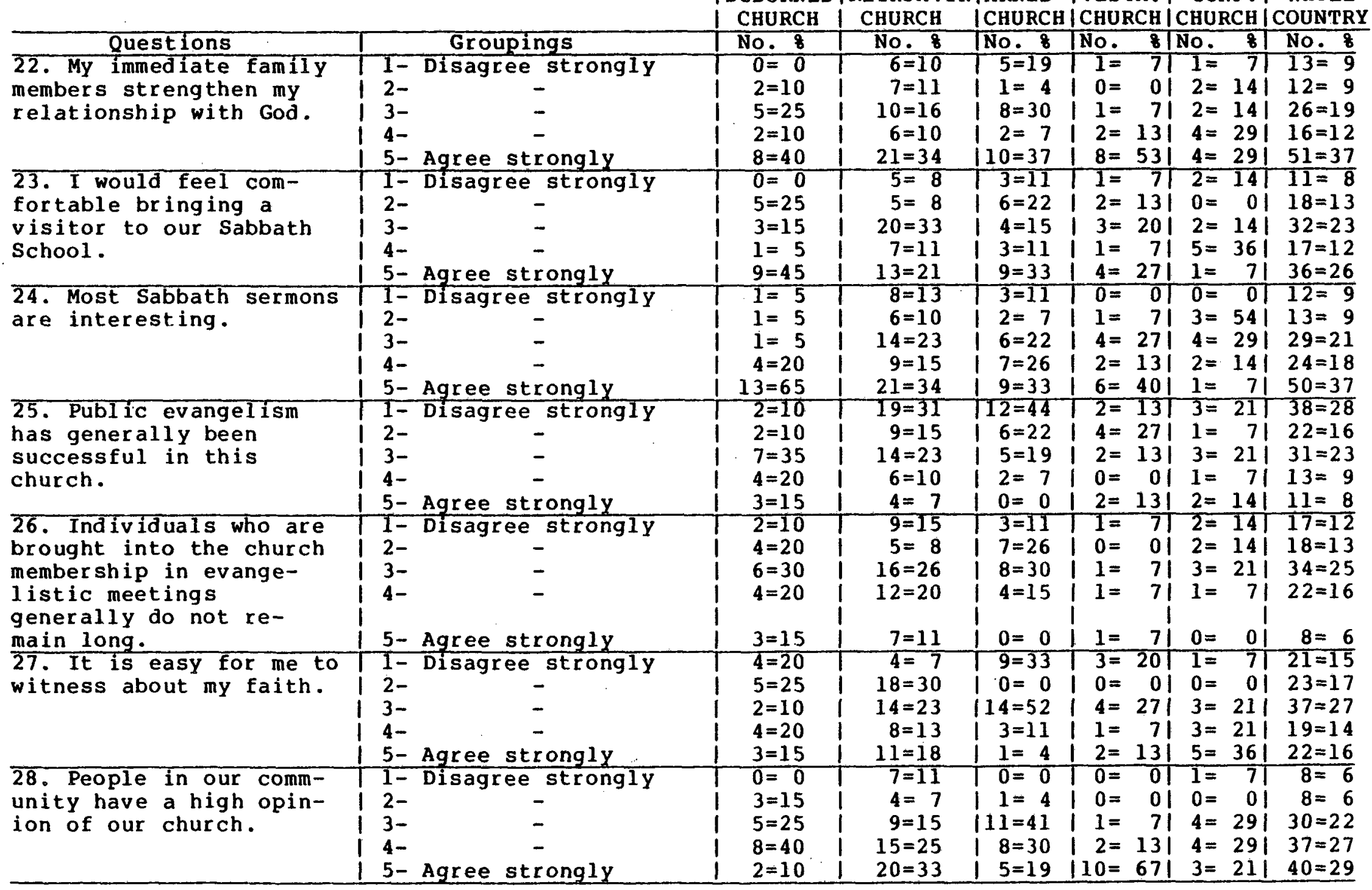


TABLE 6 Continued

ISUDURNES |REYKJAVIK|ARNES IVESTM. I CONF. I WHOLE

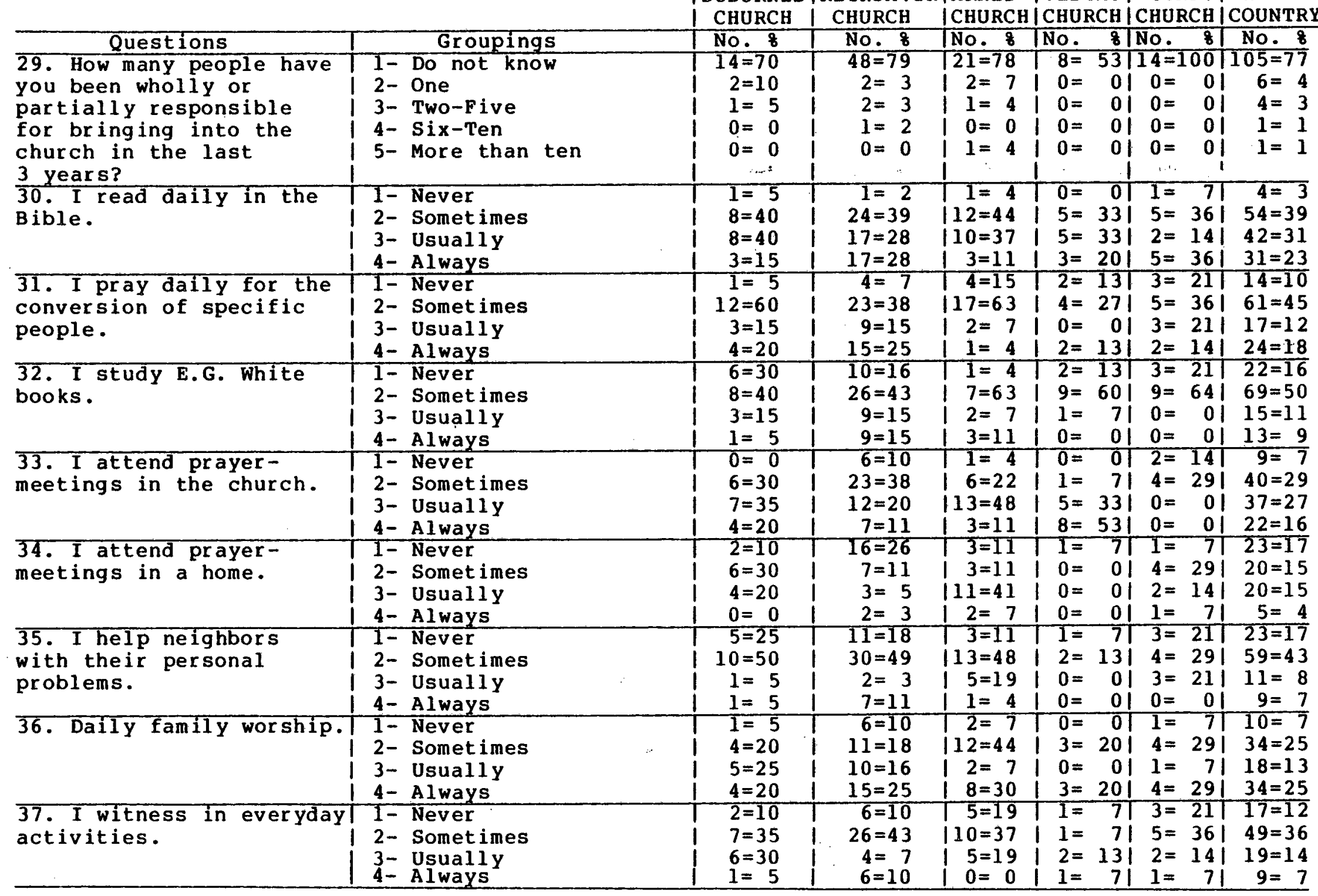


TABLE 6 Continued

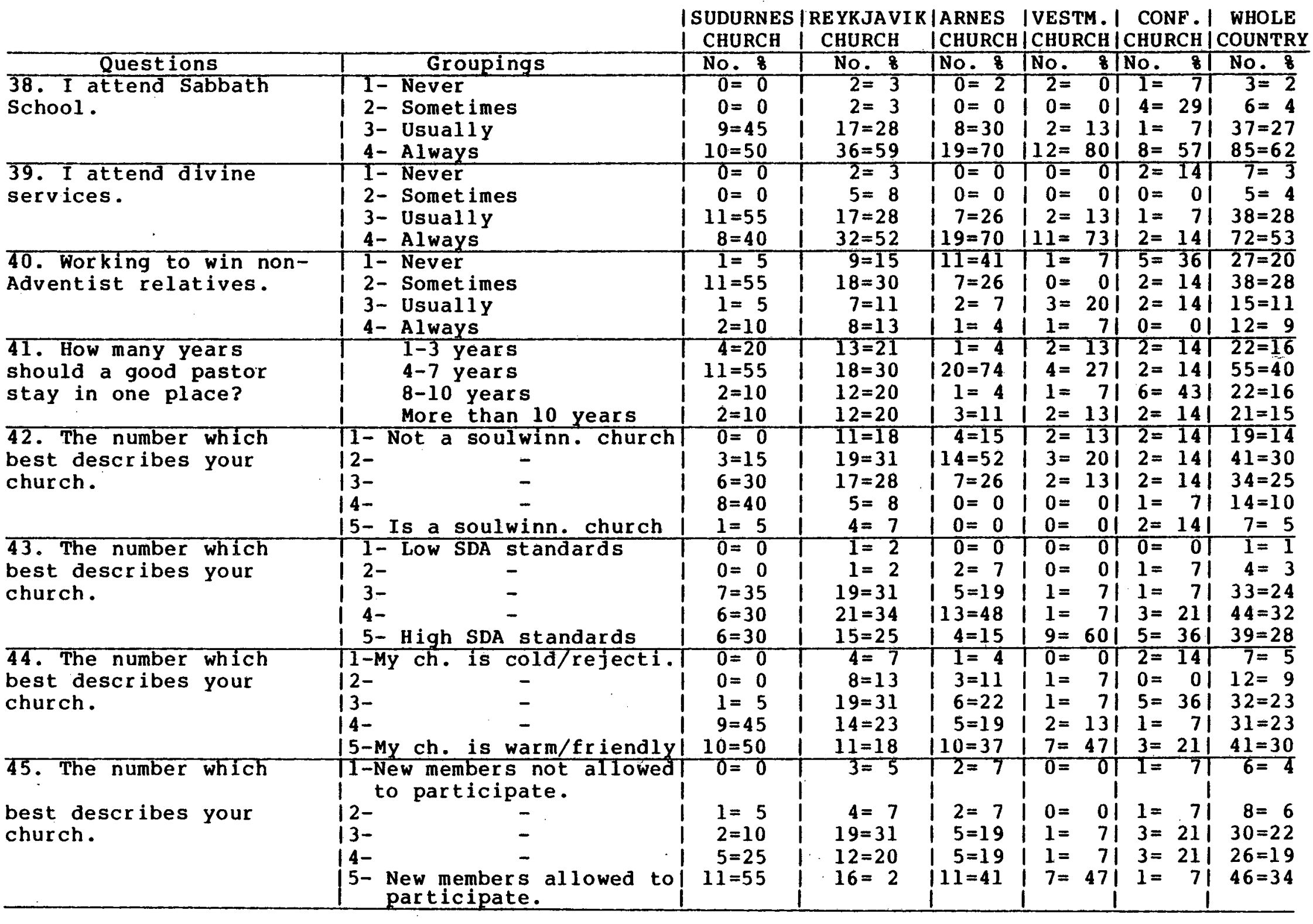




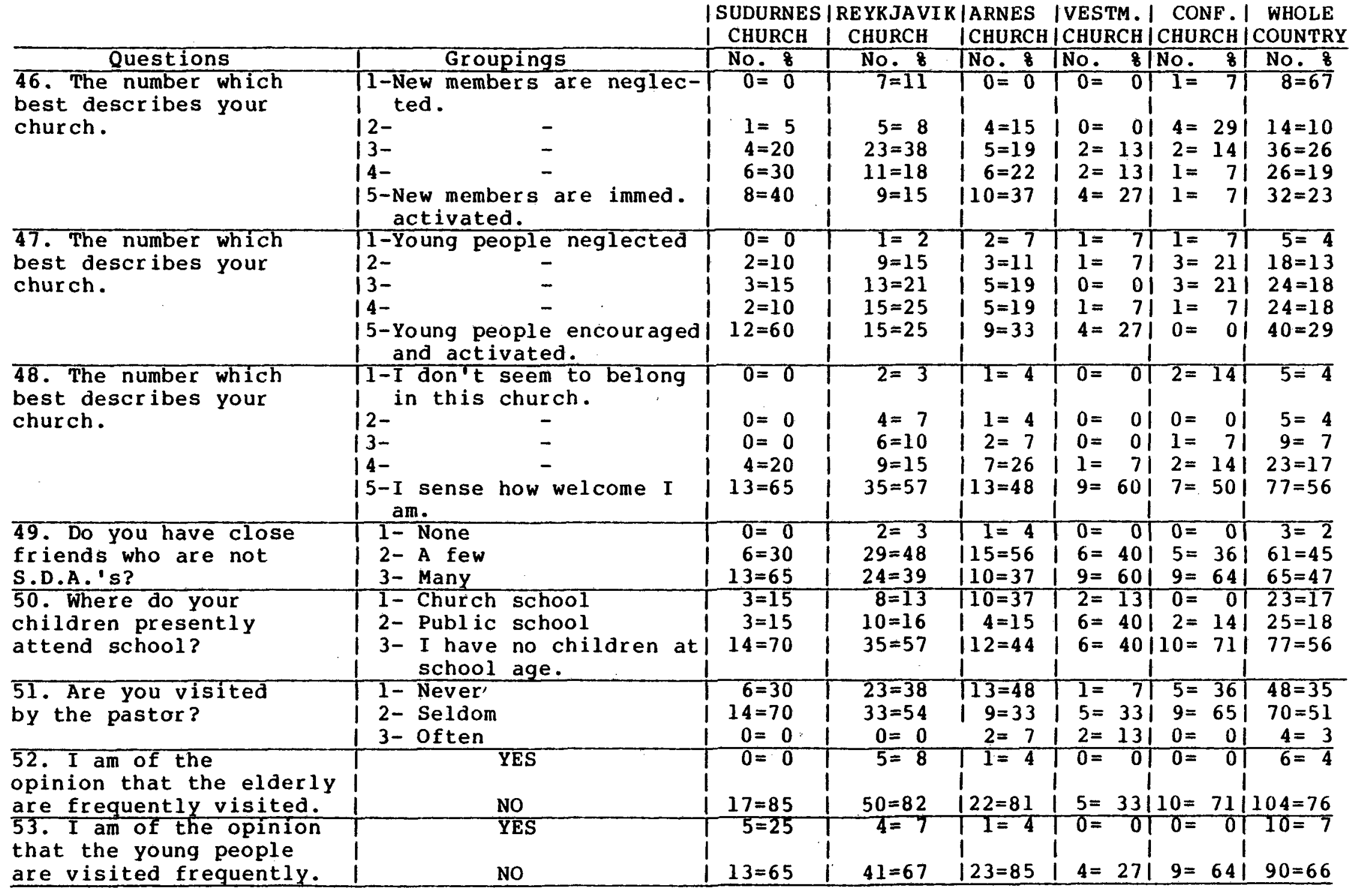


TABLE 6 Continued

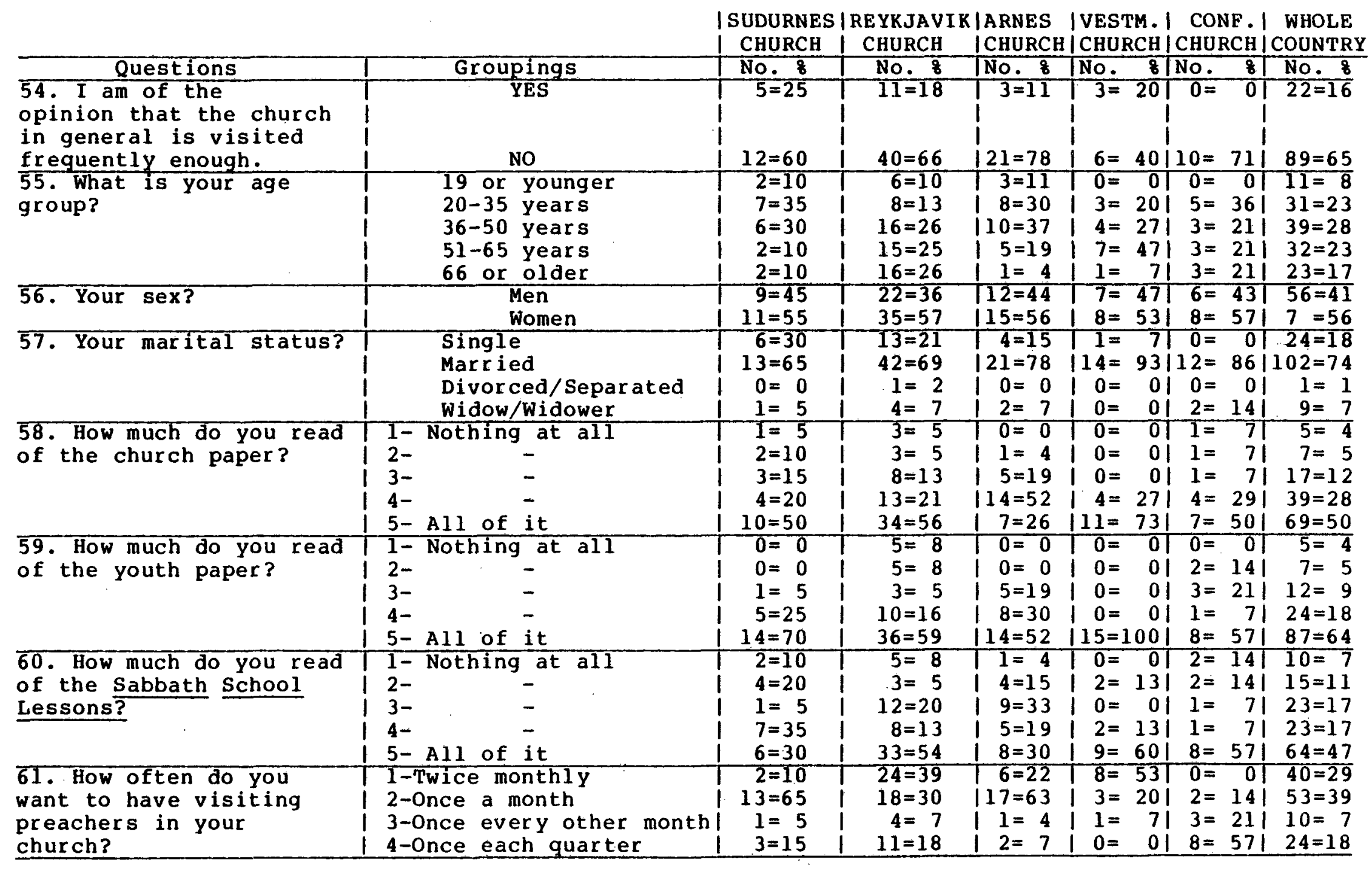


TABLE 6 Continued

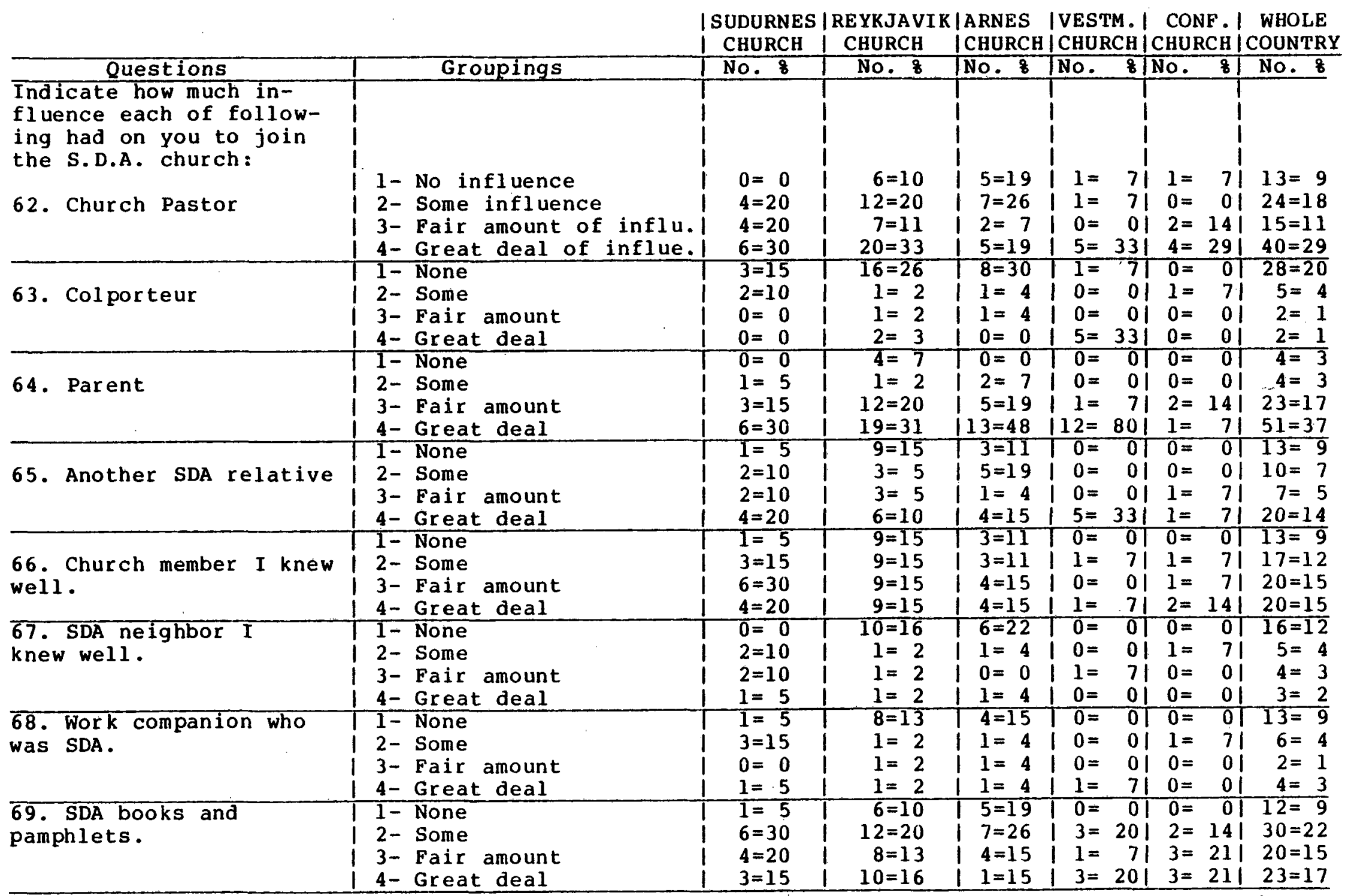


TABLE 6 Continued

\begin{tabular}{|c|c|c|c|c|c|c|c|c|c|}
\hline & & ISUDURNE: & REYKJAV & ICHIDCH & IVEST & & CON & IF. 1 & WHOLE \\
\hline & & I CHURCH & CHURCH & I CHURCH & & & CHUE & $\mathrm{CHO}$ & \\
\hline Questions & Groupings & No. 8 & No. 8 & No. 8 & No. & 81 & No. & 81 & No. 8 \\
\hline 70. Dorcas & $1-$ None & $5=25$ & $12=20$ & $6=22$ & $0=$ & 01 & $1=$ & 71 & $24=18$ \\
\hline & 2- Some & $1=5$ & $2=3$ & $3=11$ & $2=$ & 131 & $0=$ & 01 & $8=6$ \\
\hline & i 3-Fair amount & $1=5$ & $1=2$ & $2=7$ & $1=$ & 71 & $0=$ & 01 & $5=4$ \\
\hline & i 4-Great deal & $0=0$ & $2=3$ & $2=4$ & $2=$ & $13 i$ & $0=$ & 01 & $5=4$ \\
\hline 71. Bible Correspond. & T-None & $7=35$ & $8=13$ & $5=19$ & $0=$ & 01 & $0=$ & 01 & $20=15$ \\
\hline School & I 2- Some & $2=10$ & $7=11$ & $3=11$ & $0=$ & 01 & $3=$ & 211 & $15=11$ \\
\hline & $\begin{array}{l}\text { 3- Fair amount } \\
\text { 4-Great deal }\end{array}$ & $\begin{array}{l}1=5 \\
1=5\end{array}$ & $\begin{array}{l}3=5 \\
5=8\end{array}$ & $\left\{\begin{array}{l}1=4 \\
2=7\end{array}\right.$ & $\begin{array}{l}0= \\
2=\end{array}$ & $\begin{array}{r}01 \\
131\end{array}$ & $\begin{array}{l}1= \\
0=\end{array}$ & $\begin{array}{l}71 \\
01\end{array}$ & $\begin{aligned} 6 & =4 \\
10 & =7\end{aligned}$ \\
\hline 72. Bible studies in my & 1 - None & $0=0$ & $3=5$ & $3=11$ & $0=$ & 01 & $0=$ & 01 & $6=4$ \\
\hline home. & i 2- Some & $6=30$ & $7=11$ & $6=22$ & $1=$ & $7 i$ & $1=$ & 71 & $21=15$ \\
\hline & 13-Fair amount & $3=15$ & $7=11$ & $4=15$ & $0=$ & 01 & $1=$ & 71 & $15=11$ \\
\hline & 14-Great deal & $4=20$ & $10=1$ & $1=4$ & $2=$ & 131 & $4=$ & 291 & $21=15$ \\
\hline 73. Public meetings. & T1-None & $0=0$ & $4=7$ & $3=11$ & $1=$ & 71 & $0=$ & 01 & $8=6$ \\
\hline & i 2- Some & $3=15$ & $16=26$ & $9=33$ & $0=$ & 01 & $0=$ & 01 & $28=20$ \\
\hline & i 3-Fair amount & $7=35$ & $7=11$ & $3=11$ & $1=$ & 71 & $2=$ & 141 & $20=15$ \\
\hline & 1 4-Great deal & $4=20$ & $15=25$ & $0=0$ & $0=$ & 01 & $2=$ & 141 & $25=18$ \\
\hline 74. Ingathering visit. & 1 - None & $3=15$ & $10=16$ & $7=26$ & $0=$ & 01 & $0=$ & 01 & $20=15$ \\
\hline & i 2- Some & $1=5$ & $1=2$ & $1=4$ & $0=$ & 01 & $2=$ & 141 & $5=4$ \\
\hline & i 3- Fair amount & $1=5$ & $2=3$ & $1=4$ & $0=$ & 01 & $0=$ & 01 & $4=3$ \\
\hline & I 4-Great deal & $1=5$ & $1=2$ & $0=0$ & $0=$ & 01 & $0=$ & 01 & $2=1$ \\
\hline 75. SDA Church School. & $1-$ None & $1=5$ & $3=5$ & $3=11$ & $0=$ & 01 & $0=$ & 01 & $7=5$ \\
\hline & I 2- Some & $2=10$ & $4=7$ & $1=4$ & $1=$ & 71 & $0=$ & 01 & $8=$ \\
\hline & I 3-Fair amount & $2=10$ & $5=8$ & $2=7$ & $1=$ & 71 & $0=$ & 01 & $10=7$ \\
\hline & 14-Great deal & $1=5$ & $7=1$ & $7=26$ & $9=$ & 601 & $0=$ & 01 & $24=18$ \\
\hline 76. Hlidardalsskoli. & $1-$ None & $2=10$ & $4=7$ & $3=11$ & $0=$ & 01 & $0=$ & 0 & $9=7$ \\
\hline & 2- Some & $0=0$ & $1=2$ & $1=4$ & $0=$ & 01 & $0=$ & 01 & $2=1$ \\
\hline & i 3-Fair amount & $3=15$ & $4=7$ & $2=7$ & $1=$ & 71 & $2=$ & $14 i$ & $12=9$ \\
\hline & 1 4-Great deal & $5=25$ & $8=13$ & $112=44$ & $4=$ & 261 & $2=$ & 141 & $31=23$ \\
\hline 77. Five-Day Plan. & $1-$ None & $2=10$ & $5=8$ & $7=26$ & $0=$ & 01 & $0=$ & 01 & $14=10$ \\
\hline & 2- Some & $0=0$ & $0=0$ & $1=4$ & $0=$ & 01 & $0=$ & 01 & $1=1$ \\
\hline & I 3-Fair amount & $0=0$ & $1=2$ & $0=0$ & $0=$ & 01 & $0=$ & 01 & $1=1$ \\
\hline & 14-Great deal & $0=0$ & $0=0$ & $0=0$ & $0=$ & 01 & $0=$ & 01 & $0=0$ \\
\hline 78. Other. & $1-$ None & $0=0$ & $1=2$ & $T=4$ & $0=$ & 01 & $1=$ & 71 & $3=2$ \\
\hline & 2- Some & $0=0$ & $1=2$ & $0=0$ & $1=$ & 71 & $1=$ & 71 & $3=2$ \\
\hline & i 3-Fair amount & $1=5$ & $1=2$ & $2=7$ & $0=$ & 01 & $0=$ & 01 & $4=3$ \\
\hline & | 4- Great deal & $0=0$ & $3=5$ & $1=4$ & $1=$ & 71 & $0=$ & 01 & $5=4$ \\
\hline
\end{tabular}


A School Survey.

In March 1984, the school board of Hlidardalsskoli conducted a survey among Seventh-day Adventists in Iceland. This survey was conducted in an endeavor to obtain the views and opinions of church members regarding major issues relating to Christian education and the operation of Hlidardalsskoli and local church schools. The following excerpts serve to indicate the attitudes of the majority of Adventists in Iceland. On a scale of 1 (disagree strong1y) to 5 (agree strong1y) respondents replied as follows:

\section{Questions}

1. Our church should own and operate good church schools.

Agree $\quad-23.3 \%$ Strongly agree $-71.2 \%$

3. We need our church schools to counter-balance the influence of the evolution theory.

$$
\begin{array}{ll}
\text { Neutral } & -23.8 \% \\
\text { Agree } & -26.0 \% \\
\text { Strongly agree } & -40.0 \%
\end{array}
$$

4. We need our church schools to instruct our children in Christian principles and to give them a better insight into God's plan of salvation. $\begin{array}{ll}\text { Agree } & -24.0 \% \\ \text { Strong1y agree }-67.0 \%\end{array}$

9. Our church should continue to operate Hlidardalsskoli in some form.

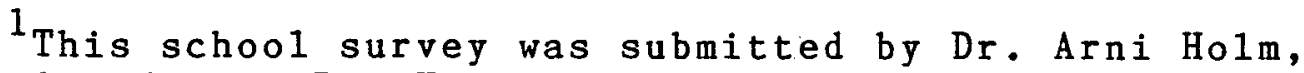
who developed it. Dr. Holm served as principal of Hlidardalsskoli during the school-years of 1982 to 1984 . 
(Survey questions continued)

12. H1idardalsskoli should offer special instruction in church activities, such as outreach.

Agree - $25.5 \%$

Strongly agree $-47.9 \%$

13. The experience of my children attending public school has been successful.

$\begin{array}{ll}\text { Neutral } & -65.8 \% \\ \text { Agree } & -15.2 \% \\ \text { Strongly agree } & -8.9 \%\end{array}$

16. Grades 8 and 9 at Hlidardalsskoli should be transferred to the church school in Reykjavik, and only grade 10 and up continue at Hlidardalsskoli.

The school survey clearly indicates that the constituency is not satisfied with the basis on which the school is presently operated. Two-thirds of the respondents (see question 16) are in favor of moving grades 8 and 9 (which presently are the only grades offered at Hlidardalsskoli) to the church school in Reykjavik. Yet, church members (76\%) do not want to dispose of the insitution, but rather desire to see it 1 operated in some other form.

Seventy-three percent are of the opinion that "special instruction in church activities, such as outreach," should be offered at Hiidardalsskoli. Meeting this desire of the church would be much in tune with one

${ }^{1}$ Arni Holm, a former principal who conducted the school survey, included this in a letter, July 25, 1984. This letter appears in appendix B. 
of the original aims of the school "to educate the young to become missionary workers."

More than 94 percent favor the maintaining of SDA church schools, which is an interesting outcome in the light of the difficulty the conference leaders have had in convincing parents of school-age children in the largest church, Rejkjavik, to send them to the church school. Responses to the question in the church survey, "Where do your children presently attend school?" reveals that 66 percent of church members in Reykjavik Church do not have any children of school-age. Another 19 percent send their children to public schools, and the remaining 15 percent send their children to the SDA church school. In other churches, parents of school-age children have no choice, since no church schools are presently open there. 


\section{APPENDIX B}

\section{LETTERS AND RESOLUTION}

1. Correspondence with the president of Iceland Conference.

2. Letter to the SDA Churches in Iceland Conference.

3. Letter from Faculty of Hlidardalsskoli to the School Board.

4. Translation of Letter from Faculty to School Board.

5. Resolution Concerning Hlidardalsskoli Adopted by the Iceland Conference Constituency Session of 1976. 


\section{ANDREWS UNIVERSITY}

BERRIEN SPRINGS, MICHIGAN 49104

Telephone: (616) $471-7771$

June 20, 1983

Pastor Erling Snorrason

Bंox 262, Reykjavik.

ICELAND

Dear Pastor Snorrason:

This is to state that steintior Thordarson is a student in good and regular standing in tise joctor of Winistry degree program in the Seninary at indrews Untversity.

fie had proposed a study of church growth factors in tive Iceland Conference of Seventh-day Adventists. We have had several sinflar studies done in other fields and all have been irelpful to the church.

ive appreclate any help your office can give in factlltating this research project for Pastor Thordarson.

Sincerely yours,

Arnold kurtz, Director

Doctor of Ministry Program

st 
President

Icelandic Conference of

Seventh-day Adventists

Pastor Erling Snorrason

Box 262, Reykjavik

Iceland.

Dear Friend, Erling.

It was nice to visit with you briefly last December in Iceland. And I want to thank you very much for your interest in my planned church growth study for Iceland Conference.

I am writing this time to request from you a letter to me, wherein you approve of my proposed research study in your conference. Kindly indicate also that your cooperation will be available. Such a cooperation would be in terms of giving me access to the official records of the conference, and paving the way for me among the churches. i.e. by requesting. when time comes for this, the church leaders, workers and church members to cooperate with me during my research. I am planning to visit Iceland either this autum or early next year for the gathering of materials.

Enclosed is a covering letter from Dr. Arnold A. Kurtz, the Director of the Doctor of Ministry program here at Andrews University. Presently, I am suggesting that the title of my research project bes "A Study of Factors Related to the Numerical Growth of the Seventh-day Adventist Church in Iceland from 1950 to 1980." .

It is my hope that we shall be able to make practical recommendations and realistic projections for future evangelism, which will contribute to a strong and steady numerical church growth in Iceland.

Eagerly awalting your reply. I want to thank you again for your kind cooperation in this matter. I shall be looking forward to working with you on this exciting project.

With Christian greetings,

Steinthor Thordarson

2605 W1110 Drive

Berrien Springs,

Michigan 49103, U.S.A. 


\section{ICELAND CONFERENCE}

\section{THE SEVENTH-DAY ADVENTIST CHURCH}

Skólavöroustíg 16 P.O. Box 262 and 883121 Reykjavík Iceland Tel. 13899 Cables Adventistar

July $8,1983$.

Steinthor Thordarson

2605 Willo Drive

Berrien Springs

Michigan 49103

U.S.A.

Dear Steinthor,

Thank you for your letter of June 20. 1983.

We can only welcome such a research as you are proposing to do in regard to factors related to the numerical growth of the Seventh-day Adventist Church in Iceland from 1950 to 1980.

Right now during the summermonths it is not possible for me to get the Conference Committee together. some members are abroad. But the officers of the Conference see no reason why such a study should not be approved. If any questions should arise I will let you know.

I shall be happy to cooperate with you to the extent I am able to do so, such as making the official records of the Conference available to you and requesting the church leaders, workers and churchmembers to co operate with you during your research.

Likewise I would ask you to be prepared to give the Conference information and data you may gather, upon request, and other items of interest as well as conclusions arrived at in your research.

Not anticipating any opposition from the Confernce Committee, you may consider this letter an approval of your proposed resarch study in the Iceland Conference.

Looking forward to see you in the autumn or next year with kindest regards.

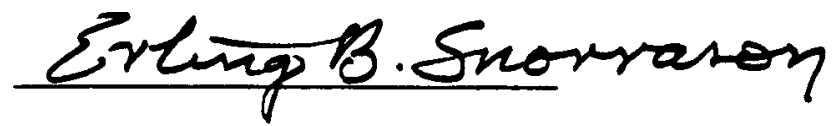

Erling B. Snorrason, President 
5.október 1983.

Til peira sem stýra

safnaóarkönnuninni

8. október 1983

Kæru bræбur,

Bestu pakkir fyrir góoar undirtektir hjá ykkur öllum við framkvæmd safnaðarkönnunarinnar sem nú fer i hönd. Meơfylgjandi eru næg eintök fyrir alla pátttakendur á hverjum stao. Eftirfarandi atrioi er nauósynlegt aơ hafa í huga pegar piơ stýriơ pessari könnun hvíldardaginn 8 . október.

1. Tilkynnio i uphafi aơ stjórn Samtakanna sé heilshugar á bak vió pessa könnun. Hún hefur gert sampykkt par aó lútandi.

2. Einnig, aó allir prestar safnađarins styðja könnunina heilshugar.

3. Aơ petta sé viðleitni til aơ fá eins konar röntgenmynd af andlegu og félagslegu ástandi safnaóarmeómlima, svo og viơhorfum peirra til ýmissa málefna er við̌koma söfnuơinum.

4. Könnunin fer fram samtímis á eftirfarandi stöoum: Akureyri, Fáskrúớfirớ, Vestmannaeyjum, Keflavík, Reykjavík, Selfossi og Hlíđardalsksóla.

5. Við viljum engin nöfn, og paó verður engin leið fyrir okkur ađ vita hver hefur svaraó á einstökum blöđum.

6. Hvetjið fólk til aơ svara af einlægni og hreinskilni, til pess ađ könnunin gefi sem réttasta mynd.

7. Skýrt verour frá niðurstöoum í Bræơrabandinu næsta vor.

8. Pessi könnun, ef vel tekst til, getur leitt til betri pjónustu prestanna fyrir safnaorfólkió, próttmeira safnóarlífs og öflugra sálnavinnandi starfs. 
9. Hafió næg skriffæri tiltæk svo aơ allir viðstaddir geti svaraó samtímis.

10. Látió alla svara hverri spurningu samtímis. Pannig getur stjórnandi útskýrt vafaatriði einu sinni fyrir alla í einu.

11. Forơist um fram allt aơ gefa dæmi um hvernig fólk geti svaraó spurningunum á síoustu blaósíounni. En alls staơar annars staóar má útskýra og gefa dæmi. A síoustu blađsíounni á fólk ađeins aó skrifa tvö-prjú oró í hverja línu,og pá pađ sem peim kemur fyrst í hug. Petta getio piơ aơ sjálfsögou útskýrt fyrir peim.

12. Könnunin er aðeins fyrir skírða meðlimi.

13. Um leiơ og könnunni lýkur skal safna saman blöounum og innsigla í stóru umslagi i návist safnađarins.

14. Vinsamlegast sendið blöðin til mín á skrifstofu aóventista Skólavöroustíg 16,Reykajvík, vio fyrsta tækifæri.

Ég sendi öllum bestu kveđjur og pakklæti fyrir hjálpina vió aó veita okkur dýrmætar upplýsingar, sem væntanlega veróa söfnuôinum til heilla síoar meir.

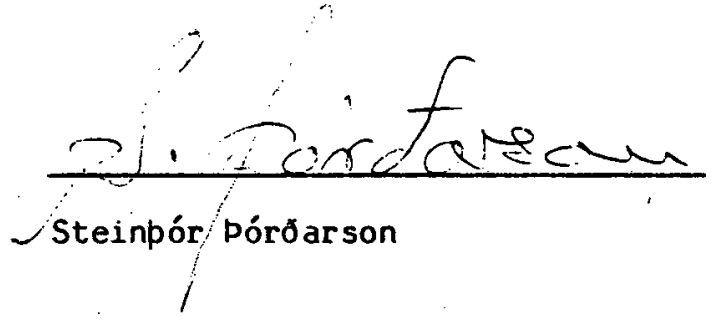

$\mathrm{SP} / \mathrm{ebg}$ 


\section{HLİDARDALSSKÓLI}

OLFUSI. ARNESSYSIU

SImat68: MIIdordolsskbII

5. febrúar, 1982

Til skólanefndar Hlídardalsskóla.

Um leid og vid malum aindregid med ad tilgangur og markmid Hlídardalsskóla verði endurskoðud á raunhæfum grundvelli viljum via undirstrika fyrri ályktun okkar frá 29/2, 1981 um að jafnuel bó starfslid yrði aukið sé einhlida fjölgun utansafnadarunglinga vid skólann óheillavænleg og samræmist ekki raunverulegu markmidi skólans. f.ð okkar mati yrði slík fjölgun ákaflega varhugaverð og gerdi enn ólíklegri möguleikann á ad uppfylla marknið skálans og veikti jafnframt til muna siðferdislegan stuðrning peirra sem starfa við skólann. Auk bess hefur - reynsla lidinna ára sýnt ad slíkt prógram hefur of neikvæd áhrif á okkar unglinga til ad réttlata olíka tilraun enn einu sinnt.

Kennarafundur Hlidardalsskóla. 
Translation of a Letter From the Faculty of

HIidardalsskoli to its School-board.

While strongly recommending that the purpose and goal of Hlidardalsskoli be reviewed on a realistic basis, we desire to emphasise our previous resolution of February 2, 1981, that even though increase in staff would take place, the one-sided increase of non-Adventist youth at the school will prove counter-productive and not in keeping with the real goal of the school. According to our view, such increase would be very questionable and would make the possibility of reaching the school's aim even more unlikely, and would at the same time weaken considerably the moral support provided by those who work at the school. Furthermore, the experience of past years has shown that such a program effects a too negative influence on our youth to justify the repetition of still another experiment of same kind. 
The conference constituency meeting held in April,

1976, adopted the following resolutions:

Whereas we realize the importance schools have for the Adventist youth, and since surveys have shown that where there are no Adventists schools only about 15 percent of our youth unite with the church, it is resolved

1. that preparation continue to establish schools in our churches;

2. that the plan which the conference has for Hlidardalsskoli be continued (that is, that the school be operated first of a11 as an Adventist school with a maximum of 10 percent from non-Adventist homes). Next year, however, the ratio would be unfavorable since the maximum number of Adventist youth is 17 and the school could recommend for admission about $8-10$ more students (non-Adventist). This will mean an unbalanced budget for next school-gear, which leads us to appeal for help to both the Northern Europe Division and the church members.

A joint meeting of the Hlidardalsskoli board and the conference executive committee convened on April 8, 1976, and voted the following action:

That the number of Adventist students next school-year be not less than 60 percent of the total number of students, on the condition

1. that non-Adventist students come solely from among those presently attending, and who have the recommendation of the faculty, as well as other students specially selected;

2. that the goal be to decrease still further the number of non-Adventist students in following schoool-years.

1Braedrabandid, no. 5, 1976, p. 18 .

2Iceland Conference of Seventh-day Adventists

Reykjavik, Iceland, Minutes of a joint meeting of the Conference Committee and the School board of Hlidardalsskoli, April 8, 1976, action no. 16. 


\section{APPENDIX C}

\section{TABLES}

1. Table 7. Statistical Survey of Students Attending Hlidardalsskoli 1950-1982 in Regard to Church Affiliation.

2. Table 8. Number of Members Added to the SDA Church in Iceland--1950-1982--Without H1idardalsskoli Influence.

3. Table 9. Number of Years Students with SDA Background Attended Hlidardalsskoli.

4. Table 10. Number of Years Students with Non-SDA Background Attended Hlidardalsskoli. 
TABLE 7

STATISTICAL SURVEY OF STUDENTS ATTENDING HLIDARDALSSKOLI 1950-1982 IN REGARD TO CHURCH AFFILIATION

\begin{tabular}{|c|c|c|c|c|c|c|c|c|c|c|c|}
\hline & & & & & & \multicolumn{2}{|c|}{$\begin{array}{l}\text { Baptized while } \\
\text { attending* }\end{array}$} & \multicolumn{4}{|c|}{$\begin{array}{l}\text { Still attending Church at } \\
\text { least occasionally in } 1982\end{array}$} \\
\hline $\begin{array}{l}\text { School } \\
\text { Year }\end{array}$ & $\begin{array}{c}\text { SDA } \\
\text { BACKGR. }\end{array}$ & $\begin{array}{l}\text { NON-SDA } \\
\text { BACKGR. }\end{array}$ & $\begin{array}{l}\text { Total No. } \\
\text { Students }\end{array}$ & $\begin{array}{l}\text { SDA \% } \\
\text { of Students }\end{array}$ & & \begin{tabular}{|c|} 
From \\
SDA \\
HOMES
\end{tabular} & $\begin{array}{c}\text { Fron } \\
\text { NON-SDA } \\
\text { HOMES }\end{array}$ & $\begin{array}{c}\text { From } \\
\text { SDA } \\
\text { HOMES }\end{array}$ & $\%$ & $\begin{array}{l}\text { From } \\
\text { NON-SDA } \\
\text { HOMES }\end{array}$ & $\%$ \\
\hline $\begin{array}{r}1950-51 \\
52 \\
53 \\
54 \\
55 \\
\end{array}$ & $\begin{array}{r}14 \\
22 \\
20 \\
9 \\
17 \\
\end{array}$ & \begin{tabular}{|r|}
5 \\
12 \\
8 \\
3 \\
24 \\
\end{tabular} & \begin{tabular}{|l|}
19 \\
34 \\
28 \\
12 \\
41 \\
\end{tabular} & $\begin{array}{l}74 \\
65 \\
71 \\
75 \\
41 \\
\end{array}$ & & \begin{tabular}{l|}
7 \\
3 \\
2 \\
3 \\
8 \\
\end{tabular} & \begin{tabular}{l|}
1 \\
1 \\
0 \\
1 \\
0 \\
\end{tabular} & $\begin{array}{l}5 \\
1 \\
1 \\
2 \\
4 \\
\end{array}$ & & $\begin{array}{l}0 \\
0 \\
0 \\
1 \\
0 \\
\end{array}$ & \\
\hline $\begin{array}{l}\text { Average } \\
\text { per year }\end{array}$ & 16 & 10 & 27 & 65 & total & 23 & 3 & 13 & 57 & 1 & 33 \\
\hline $\begin{array}{l}56 \\
57 \\
58 \\
59 \\
60 \\
\end{array}$ & $\begin{array}{l}11 \\
11 \\
16 \\
26 \\
31 \\
\end{array}$ & $\begin{array}{l}19 \\
31 \\
34 \\
42 \\
48 \\
\end{array}$ & $\begin{array}{l}30 \\
42 \\
50 \\
68 \\
79 \\
\end{array}$ & $\begin{array}{l}37 \\
26 \\
32 \\
38 \\
39 \\
\end{array}$ & & $\begin{array}{r}0 \\
4 \\
5 \\
10 \\
7\end{array}$ & $\begin{array}{l}0 \\
1 \\
5 \\
9 \\
1\end{array}$ & $\begin{array}{l}4 \\
3 \\
7 \\
4 \\
\end{array}$ & & $\begin{array}{l}0 \\
2 \\
2 \\
0 \\
\end{array}$ & \\
\hline $\begin{array}{l}\text { Average } \\
\text { per year }\end{array}$ & 19 & 35 & 54 & 34 & & 26 & 16 & 18 & 69 & 4 & 25 \\
\hline $\begin{array}{l}61 \\
62 \\
63 \\
64 \\
65 \\
\end{array}$ & $\begin{array}{l}25 \\
26 \\
28 \\
27 \\
26 \\
\end{array}$ & $\begin{array}{l}49 \\
54 \\
60 \\
52 \\
58 \\
\end{array}$ & $\begin{array}{l}74 \\
80 \\
88 \\
79 \\
84 \\
\end{array}$ & $\begin{array}{l}34 \\
33 \\
32 \\
34 \\
31 \\
\end{array}$ & & $\begin{array}{l}9 \\
4 \\
7 \\
8 \\
0 \\
\end{array}$ & $\begin{array}{l}1 \\
2 \\
2 \\
0 \\
2 \\
\end{array}$ & $\begin{array}{l}5 \\
4 \\
4 \\
4\end{array}$ & & $\begin{array}{l}1 \\
2 \\
2 \\
2 \\
\end{array}$ & \\
\hline $\begin{array}{l}\text { Average } \\
\text { per year }\end{array}$ & 26 & 55 & 81 & 33 & . & 28 & 7 & 17 & 61 & 7 & 100 \\
\hline $\begin{array}{r}66 \\
67 \\
68 \\
69 \\
70 \\
\end{array}$ & $\begin{array}{l}20 \\
11 \\
21 \\
15 \\
18 \\
\end{array}$ & $\begin{array}{l}59 \\
64 \\
32 \\
50 \\
43 \\
\end{array}$ & $\begin{array}{l}79 \\
75 \\
53 \\
65 \\
61 \\
\end{array}$ & $\begin{array}{l}25 \\
15 \\
40 \\
23 \\
30 \\
\end{array}$ & & $\begin{array}{r}3 \\
4 \\
7 \\
11 \\
9 \\
\end{array}$ & $\begin{array}{l}0 \\
1 \\
1 \\
0 \\
1\end{array}$ & $\begin{array}{l}1 \\
3 \\
5 \\
6 \\
4 \\
\end{array}$ & $\therefore$ & $\begin{array}{l}0 \\
0 \\
1 \\
\end{array}$ & \\
\hline $\begin{array}{l}\text { Average } \\
\text { per rear }\end{array}$ & 17 & 50 & 67 & 25 & & 34 & 3 & 19 & 56 & 1 & 33 \\
\hline $\begin{array}{r}71 \\
72 \\
73 \\
74 \\
75 \\
\end{array}$ & $\begin{array}{r}20 \\
23 \\
24 \\
13 \\
8 \\
\end{array}$ & $\begin{array}{l}55 \\
58 \\
59 \\
59 \\
69 \\
\end{array}$ & $\begin{array}{l}75 \\
81 \\
83 \\
72 \\
77 \\
\end{array}$ & $\begin{array}{l}27 \\
28 \\
29 \\
18 \\
10 \\
\end{array}$ & & $\begin{array}{l}9 \\
6 \\
5 \\
0 \\
1 \\
\end{array}$ & $\begin{array}{l}2 \\
4 \\
0 \\
0 \\
1 \\
\end{array}$ & $\begin{array}{l}2 \\
3 \\
3 \\
0 \\
1 \\
\end{array}$ & & 1 & \\
\hline $\begin{array}{l}\text { Average } \\
\text { per year }\end{array}$ & 18 & 60 & 78 & 22 & & 21 & 7 & 9 & 43 & 1 & 14 \\
\hline
\end{tabular}


TABLE 7 - continued

\begin{tabular}{|c|c|c|c|c|c|c|c|c|c|c|c|}
\hline \multirow{3}{*}{$\begin{array}{r}\text { Schoo1 } \\
\text { Year } \\
1975-76 \\
77 \\
78 \\
79 \\
80 \\
\end{array}$} & \multirow{3}{*}{$\begin{array}{c}\begin{array}{c}\text { SDA } \\
\text { BACKGR. }\end{array} \\
10 \\
21 \\
21 \\
32 \\
30 \\
\end{array}$} & \multirow[b]{2}{*}{$\begin{array}{l}\text { NON-SDA } \\
\text { BACKGR. }\end{array}$} & \multirow[b]{2}{*}{$\begin{array}{l}\text { Total No. } \\
\text { Students }\end{array}$} & \multirow[b]{2}{*}{$\begin{array}{l}\text { SDA \% } \\
\text { of Students }\end{array}$} & & \multicolumn{2}{|c|}{$\begin{array}{l}\text { Baptized while } \\
\text { attending* }\end{array}$} & \multicolumn{4}{|c|}{$\begin{array}{l}\text { Still attending Church at } \\
\text { least occasionally in } 1982\end{array}$} \\
\hline & & & & & & $\begin{array}{c}\text { From } \\
\text { SDA } \\
\text { HOMES }\end{array}$ & $\begin{array}{c}\text { From } \\
\text { NON-SDA } \\
\text { HOMES }\end{array}$ & \begin{tabular}{|c|} 
From \\
SDA \\
HOMES
\end{tabular} & $\%$ & $\begin{array}{c}\text { From } \\
\text { NON-SDA } \\
\text { HOMES }\end{array}$ & $\%$ \\
\hline & & \begin{tabular}{|l|}
46 \\
18 \\
27 \\
27 \\
25 \\
\end{tabular} & $\begin{array}{l}56 \\
39 \\
48 \\
59 \\
55 \\
\end{array}$ & $\begin{array}{l}18 \\
54 \\
44 \\
54 \\
55 \\
\end{array}$ & & $\begin{array}{r}6 \\
15 \\
9 \\
6 \\
0 \\
\end{array}$ & $\begin{array}{l}5 \\
3 \\
2 \\
1 \\
1 \\
\end{array}$ & \begin{tabular}{r|}
5 \\
13 \\
8 \\
6 \\
0 \\
\end{tabular} & & $\begin{array}{r}0 \\
1 \\
2 \\
1 \\
+\quad 1 \\
\end{array}$ & \\
\hline $\begin{array}{l}\text { Average } \\
\text { per year }\end{array}$ & 23 & 29 & 51 & 45 & & 36 & 12 & 32 & 89 & 5 & 42 \\
\hline $\begin{array}{r}81 \\
82 \\
\end{array}$ & $\begin{array}{l}15 \\
11 \\
\end{array}$ & $\begin{array}{l}18 \\
30 \\
\end{array}$ & $\begin{array}{l}33 \\
41 \\
\end{array}$ & $\begin{array}{l}45 \\
27 \\
\end{array}$ & & $\begin{array}{l}7 \\
0 \\
\end{array}$ & $\begin{array}{l}0 \\
0 \\
\end{array}$ & $\begin{array}{l}7 \\
0 \\
\end{array}$ & & & \\
\hline $\begin{array}{l}\text { Average } \\
\text { per year }\end{array}$ & 13 & 24 & 37 & 36 & $\begin{array}{l}\text { Grand } \\
\text { Total }\end{array}$ & 175 & 48 & 115 & & 19 & \\
\hline
\end{tabular}

Note: This chart was prepared in 1982 by Gudmundur Olafsson. Olafsson taught at Hlidardalsskoli for about 20 years, the last 3 jears of which he served as the principal (1979-82). Used with the author's permission, this chart has been slightly altered in format and the percentages have been rounded out.

* "Baptized while attending" includes students who are baptized after leaving the school. 
TABLE 8

NUMBER OF MEMBERS ADDED TO THE SDA CHURCH IN ICELAND 1950-1982

WITHOUT HLIDARDALSSKOLI INFLUENCE

\begin{tabular}{|c|c|c|}
\hline Year & $\begin{array}{l}\text { Baptisms }{ }^{1} \text { from } \\
\text { SDA Background }\end{array}$ & $\begin{array}{c}\text { Baptisms }{ }^{1} \text { from } \\
\text { non-SDA background } \\
\end{array}$ \\
\hline 1951 & 3 & 21 \\
\hline 1952 & 2 & 6 \\
\hline 1953 & 0 & 3 \\
\hline 1954 & 1 & 1 \\
\hline 1955 & 1 & 2 \\
\hline 1956 & 0 & 0 \\
\hline 1957 & 0 & 3 \\
\hline 1958 & 1 & 4 \\
\hline 1959 & 1 & 10 \\
\hline 1960 & 1 & 8 \\
\hline 1961 & 1 & 10 \\
\hline 1962 & 0 & 7 \\
\hline 1963 & 0 & 3 \\
\hline 1964 & 1 & 6 \\
\hline 1965 & 1 & 6 \\
\hline 1966 & 1 & 1 \\
\hline 1967 & 0 & 4 \\
\hline 1968 & 1 & 6 \\
\hline 1969 & 0 & 0 \\
\hline 1970 & 2 & 6 \\
\hline
\end{tabular}


TABLE 8 -- continued

\begin{tabular}{|c|c|c|}
\hline Year & $\begin{array}{l}\text { Baptisms from } \\
\text { SDA background }\end{array}$ & $\begin{array}{c}\text { Baptisms from } \\
\text { non-SDA background }\end{array}$ \\
\hline$\overline{1971}$ & 1 & 9 \\
\hline 1972 & 3 & 8 \\
\hline 1973 & 0 & 2 \\
\hline 1974 & 0 & 3 \\
\hline 1975 & 0 & 6 \\
\hline 1976 & 0 & 0 \\
\hline 1977 & 1 & 3 \\
\hline 1978 & 2 & 1 \\
\hline 1979 & 1 & 0 \\
\hline 1980 & 3 & 5 \\
\hline 1981 & 1 & 2 \\
\hline 1982 & 0 & 0 \\
\hline & 29 & 146 \\
\hline
\end{tabular}

Note: These figures were gleaned from the membership records of the Iceland Conference.

${ }^{1}$ Adequate information is not at my disposal to estimate the approximate number of inactive church members who joined the church without ever attending

Hlidardalsskoli. It would be a worthwhile subject for further study. 
TABLE 9

NUMBER OF YEARS STUDENTS, WITH SDA BACKGROUND ATTENDED HLIDARDALSSKOLI

\begin{tabular}{|c|c|c|c|c|c|c|c|}
\hline \multirow{2}{*}{$\begin{array}{l}\text { Five-Year } \\
\text { Periods }\end{array}$} & \multicolumn{5}{|c|}{ No. of years in school } & \multirow{2}{*}{$\begin{array}{l}\text { Total No. } \\
\text { of stud's }\end{array}$} & \multirow{2}{*}{$\begin{array}{c}\text { Average No. } \\
\text { of years }\end{array}$} \\
\hline & 1 & 2 & 3 & 4 & 5 & & \\
\hline $1951-55$ & 17 & $\overline{11}$ & 17 & 4 & & 49 & 2.4 \\
\hline $56-60$ & 4 & 12 & 22 & 15 & 1 & 54 & 2.9 \\
\hline $61-65$ & 6 & 11 & 15 & 11 & 1 & 44 & 2.8 \\
\hline $66-70$ & 9 & 14 & 12 & 8 & 1 & 44 & 2.5 \\
\hline $71-75$ & 14 & 17 & 15 & & & 46 & 2.1 \\
\hline $76-80$ & 10 & 15 & 18 & 12 & & 55 & 2.6 \\
\hline No. Stud's & 60 & 80 & 99 & 50 & 3 & $\overline{292}$ & 2.5 \\
\hline *Non-SDA'S & 10 & 24 & 10 & 4 & & 48 & 2.2 \\
\hline Difference & 50 & 56 & 89 & $\overline{46}$ & $\overline{3}$ & 244 & 2.6 \\
\hline$\% * \%$ & 20.5 & 22.9 & 36. & 18. & $\overline{1}$ & & \\
\hline
\end{tabular}

*"Non-SDA" represents students from non-SDA background who were bapitzed during their stay at Hlidardalsskoli.

**The percentage of the total number of students with SDA background who stayed $X$ number of years.

TABLE 10

NUMBER OF YEARS STUDENTS WITH NON-SDA BACKGROUND ATTENDED HLIDARDALSSKOLI

\begin{tabular}{|c|c|c|c|c|c|c|}
\hline \multirow{2}{*}{$\begin{array}{l}\text { Five-Year } \\
\text { Periods }\end{array}$} & \multicolumn{4}{|c|}{ No. of years in school } & \multirow{2}{*}{$\begin{array}{l}\text { Total No. } \\
\text { of stud's }\end{array}$} & \multirow{2}{*}{$\begin{array}{c}\text { Average No. } \\
\text { of years }\end{array}$} \\
\hline & 1 & 2 & 3 & 4 & & \\
\hline $1951-55$ & 20 & 6 & & & 26 & 1.2 \\
\hline $56-60$ & 50 & 32 & 6 & 5 & 93 & 1.6 \\
\hline $61-65$ & 105 & 44 & 15 & 6 & 170 & 1.5 \\
\hline $66-70$ & 111 & 34 & 9 & 4 & 158 & 1.4 \\
\hline $71-75$ & 112 & 64 & 12 & 2 & 190 & 1.5 \\
\hline $76-80$ & 74 & 18 & 2 & 1 & 95 & 1.3 \\
\hline $\begin{array}{l}\text { No. Stud's } \\
\text { Baptized }\end{array}$ & $\begin{array}{r}472 \\
10\end{array}$ & $\begin{array}{r}198 \\
24\end{array}$ & $\begin{array}{l}44 \\
10\end{array}$ & $\begin{array}{r}18 \\
4\end{array}$ & $\begin{array}{r}732 \\
48\end{array}$ & $\begin{array}{l}1.5 \\
2.2\end{array}$ \\
\hline Total & 482 & 222 & 54 & 22 & 780 & 1.5 \\
\hline$\%$ & 61.8 & 28.5 & 6.9 & 2.8 & & \\
\hline
\end{tabular}

*The percentage of the total number of non-SDA students who stayed $X$ number of years. 


\section{APPENDIX D}

1. Statement of Mission

2. Setting Numerical, Controllable Church

Baptismal Objectives

3. Work Sheet (for objectives of Mission) 
A statement of mission for the Church.

It is the purpose and mission of this church to witness to Jesus Christ as our Lord and Saviour, as a Cbristian church in our community to continue to find ways to share with our community the special message entrusted to us as Seventh-day Adventists, and to win as many to Christ and His message as God shall eaable us to do.

It is our purpose that this church shall be a transforming fellowship in which the members can go on to maturity in Christ and to equip them for Christian service according to their gifts and abilities.

Because our church is part of a world moverient it stall be our purpose to reach out to the world, and to support our world mission through the organizations and institutions of the denomination of which we are a part.

\section{OUR MISSION}

We, the members of the Dowagiac Seventh-day Adventist Church, as part of the world Seventh-day Adventist organization, acknowledge our responsibility in fulfilling the comission given us by Christ to prepare the way for His Second Coming. To accomplish this, our mission is as follows:

1. To srow closer to Christ through personal Bible study, - prayer, and individual comitment.

2. To uphold Christ before all within the church-adults, youth, and children--through worship, instruction, fellowship, and personal concern.

3. To present Christ to the people of Dowagiac and the surrounding areas through comunity service and personal witness.

4. To carry Christ to the world field tinrough prayer, financial contribution, and personal service. 
One desirable, if not essential, characteristic of an operational objective is that it be controllable; that is, that it state a desired condition over which those setting the objective have some control. The objective should also be measurable in some way.

Numerical baptismal goals or objectives have the double advantage of being easily measurable and of inspiring people with a conceivable vision, or picture, of the goal toward which evangelistic objectives are aimed.

However, numerical baptismal objectives, as they are usually stated, also have the disadvantage of not being directly controllable; they depend upon the indeterminate factor of human choice or free will on the part of those to be baptized.

This disadvantage, however, can be overcome in a way whics will retain all the advantages of the numerice? goal if evangelistic objectives are stated somewhat in tine pattern modeled below, with controliable evangelistic preparations leading up to and forming the basis for the actual baptismal objective, which is stated last:

The evangelistic objectives of the Severith-day Adventist Church for the calendar year 1980 are as follows:

1. To hol à one major public evangelistic campaign in October and November.

2. To initiate 100 new Bible stuay contacts by April 1, following through with all responses.

3. To develop 10 neighborhood Bible study groups by September 1, focusing on nonmembers.

4. To establish 10 evangelistic prayer groups meeting regularly from February 1 through the close of the evangelistic meetings.

5. To petition the Lord through the prayer groups, other church meetings and individually to add 50 new members to our church by baptism before the end of the year 1980.

As can be readily seen, this pattern leaves the "faith factor" intact while recognizing the extent to which the fulfillment of this particular numerical goal lies in other hands than our own. 
APPENDIX E

1. The Spiritual Gifts Inventory 


\section{BEFORE YOU BEGIN}

Each of the questions on the following pages is designed to evaluate a specific spiritual gift.

Read each question thoughtfully, then circle the number that indicates the DEGREE to which the statement is TRUE or FALSE in your life.

It is important that you circle a number for every question.

If it is always, or completely false, circle 1.

If it is usually or mostly false, circle 2.

If it is occasionally or partially true or false, circle 3 .

If it is usually or mostly true, circle 4.

If it is always or completely true, circle 5 .

If this evaluation is really to benefit you, you will need to be absolutely honest in every response! When you have answered all the questions follow the instructions printed at that point in this booklet and you will be able to evaluate the results of this inquiry yourself. Do not read ahead, however; take just one page at a time.

One final note before you begin. This investigation into your spiritual gifts will evaluate your past and present experiences more than your hopes and desires for the future. For this reason it will speak more intimately to those who have been members of the Lord's family for some months or more, than to those who are recently "new born" in Jesus. So if you have only recently accepted the Lord, try to think of the questions in anticipation rather than what you have already experienced. 
1. I feel very comfortable directing activities involving people

2. I have been called directly by God to hold a highly respon- $\quad \begin{array}{lllll}1 & 2 & 3 & 4 & 5\end{array}$ sible position of leadership among God's people

3. I can discern the motives

$\begin{array}{lllll}1 & 2 & 3 & 4 & 5\end{array}$ of most people

4. I find it easy to ask someone to make a decision for Jesus

5. When someone is hurting I am able to say something that genuinely comforts

6. Even when God's will is not clear to me I still step out

$\begin{array}{lllll}1 & 2 & 3 & 4 & 5\end{array}$ in faith

7. In an appeal for a worthy cause I'm among the first to give

8. I prefer to busy myself "behind the scenes" at a

$\begin{array}{lllll}1 & 2 & 3 & 4 & 5\end{array}$ social gathering

9. I enjoy helping people by having them home

$\begin{array}{lllll}1 & 2 & 3 & 4 & 5\end{array}$ for meals

10. Most of my "prayer time" is spent dealing with the needs

$\begin{array}{lllll}1 & 2 & 3 & 4 & 5\end{array}$ of others

11. Salvation by faith alone is a truth I clearly

$\begin{array}{lllll}1 & 2 & 3 & 4 & 5\end{array}$ understand

12. When faced with a complex problem I am able to identify the key factors that will lead to a solution

13. I would have felt it totally worthwhile to be one of the five

$\begin{array}{lllll}1 & 2 & 3 & 4 & 5\end{array}$ missionaries killed taking the gospel to the Auca Indians

14. Helping society's outcasts, like drunks and addicts, would or $\quad \begin{array}{lllll}1 & 2 & 3 & 4 & 5\end{array}$ does bring me great satisfaction

15. Living in rather primitive circumstances in a foreign country would not worry me as long as I could share the gospel

16. I'm excited about visiting church members in their homes on a regular basis

17. People in trouble are encouraged when Italk with them

18. I feel very much at home leading out in any Bible teaching

$\begin{array}{lllll}1 & 2 & 3 & 4 & 5\end{array}$ setting

19. If someone is emotionally upset I can explain why they are upset and what they should do 
20. There is a good spirit of unity and enthusiasm when I'm in charge

21. I'm usually consulted when matters of doctrine are being discussed

22. I can tell whether a person is being influenced more by the Lord or by Satan

23. Regularly I have the privilege of leading souls to Jesus

24. I am often asked to help those in trouble resolve their problems

25. I have complete faith the Lord will work out every problem that comes my way

26. I keep my purchases to a real minimum when appeals are

$\begin{array}{lllll}1 & 2 & 3 & 4 & 5\end{array}$ made for others

27. When asked to help, even if I'm busy, I try to help

28. I always make it a point to greet strangers and when it's appropriate I invite them home

29. People in need regularly come to my mind, and I take their

$\begin{array}{lllll}1 & 2 & 3 & 4 & 5\end{array}$ needs to God in prayer

30. With the help of appropriate study materials I can find what God's Word teaches on most topics

31. I resolve "people" or relational problems in ways that make

$\begin{array}{lllll}1 & 2 & 3 & 4 & 5\end{array}$ those affected satisfied

32. The idea of dying for my faith does not frighten me

33. I am extremely sensitive to the needs of the handicapped and enjoy talking with them and offering my help

34. I could cope with separation from loved ones in order to share the gospel in a foreign land

35. It does, or I believe it would, bring great satisfaction to occupy the same pulpit each week of the year

36. People often tell me, "God used you. You dealt exactly with my need

37. I can prepare a logical class outline for a Bible class

38. I know when to take an uncompromising stand, and when to take a middle course between alternate positions 
39. I'm happy to accept the loneliness that comes with leadership

40. When leaders are being chosen my opinions are normally $\quad \begin{array}{llll}1 & 2 & 3 & 4: 5\end{array}$ sought.

41. If someone came and asked me for money, I would know if $\begin{array}{lllll}1 & 2 & 3 & 4 & 5\end{array}$ the person really needed help or was a fraud

42. People under conviction seek me out and ask how they should surrender their lives to Jesus

43. People in need of good advice ask me for it

44. I take God's promises at face value and believe them even if the fulfillment seems impossible

45. If I totaled my personal and church contributions they would probably equal a fifth or more of my income

46. If a church or community leader asked me to do a menial task like sweeping a sidewalk, I'd be delighted to do it

47. There are often a good number of people at our home for lunch after church service

$\begin{array}{lllll}1 & 2 & 3 & 4 & 5\end{array}$

$\begin{array}{lllll}1 & 2 & 3 & 4 & 5\end{array}$

$\begin{array}{lllll}1 & 2 & 3 & 4 & 5\end{array}$

$\begin{array}{lllll}1 & 2 & 3 & 4 & 5\end{array}$

$\begin{array}{lllll}1 & 2 & 3 & 4 & 5\end{array}$

$\begin{array}{lllll}1 & 2 & 3 & 4 & 5\end{array}$

48. I have a long and growing list of people whom I remember $\begin{array}{llllll}1 & 2 & 3 & 4 & 5\end{array}$ in prayer

49. I am perfectly at ease answering anyone's Bible questions

50. I have the ability to develop progressive programs and see them through to a successful conclusion

51. If a civil court sentenced me to death for preaching the gospel, I'd be content to die for the Lord

52. I'd be very willing to help a shoddily dressed drunk across a busy intersection

53. I could happily adapt to the culture of another country if called to minister there

54. I see myself as a "shepherd" in my church with a total dedication to the welfare of all the "sheep."

55. God uses me to lift the spirits of the discouraged

56. Bible teachings come quickly to mind when I deal with a problem

57. I can predict with unusual accuracy the long term results of decisions 


\section{HOW TO EVALUATE YOUR RESPONSES}

Check back and make sure you have circled a number for every one of the 57 questions.

Now fold back the flap of the last page of this booklet. There you will find 57 spaces. Note the number you circled for question 1 , and write that number in the first space. Note the number you circled for question 2 , and write that number in the second space, and so on until you have placed a number in each of the 57 squares on the flap.

Then add the numbers from left to right. That is, add together the number in square 1 , plus the number in square 20 , plus the number in square 39 . Write the total in the square headed TOTAL, as illustrated.

When all the scores are totalled, scan down the list and circle the highest scores. There will probably be a cluster of from two to four that are quite close together.

Think for a moment about the gifts you have just circled, the ones with the highest scores. Which one would you like to consider FIRST for further study and experimentation? Place a check beside that gift on the score sheet attached to page 11 .

For example:

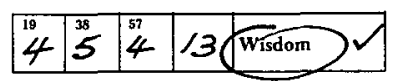

Now write the names of the gifts with the highest scores on the blank lines at the top of page 10 and you will have a permanent record of this initial investigation of your personal spiritual gifts. 


\section{FINALLY}

Place in the spaces below the gifts on which you scored the highest. You will probably find two to four scores that are quite close together. This is your probable "gift cluster."

1.

2.

3.

4.

Also add below any gifts you thought you had, even if the scores were not among the highest. These need further consideration along with those listed above.

5.

6.

You have just taken an important step in discovering your spiritual gift or gifts. But a test can only indicate areas of high probability. It does not mean for certain that these are your gifts. You now need to go further to confirm what gifts God has given you for use in His service. These would include such important activities as daily prayer, a study of the New Testament chapters dealing with spiritual gifts, and prayerful experimentation with the gifts that show the greatest promise. Hopefully; under the guidance of the Holy Spirit, you will do all this and more.

The data from over 2,000 Christians whose responses have been analyzed suggests that any score below 9 represents such a low probability of giftedness in any area that it ought not to be considered positively at this time.

If you would like to send for some companion materials to help you explore this important subject, especially the meaning of your personal spiritual gifts, see the back cover of this booklet. 
Gifts mentioned in the New Testament but not included in this evaluation are: healing, miracles, tongues, interpretation of tongues, celibacy, voluntary poverty, and exorcism. These gifts are so spectacular or obvious that those who have them do not need help in recognizing the fact! But they would still need the affirmation of the other members of the local congregation in their appropriate use.
Male

Name

$\square$ Female

Example:

Score I Score 2 Score 3 Total

GIFT

$3+4+2=9$

\begin{tabular}{|c|c|c|c|}
\hline 1 & 20 & 39 & Administration \\
\hline 2 & 21 & 40 & Apostleship \\
\hline 3 & 22 & 41 & Discernment \\
\hline 4 & 23 & 42 & Evangelism. \\
\hline 5 & 24 & 43 & Exhortation \\
\hline 6 & 25 & 44 & Faith \\
\hline 7 & 26 & 45 & Giving \\
\hline 8 & 27 & 46 & Helps \\
\hline 9 & 28 & 47 & Hospitality \\
\hline 10 & 29 & $\overline{48}$ & Intercession \\
\hline 11 & 30 & 49 & Knowledge \\
\hline 12 & 31 & 50 & Leadership \\
\hline$\overline{13}$ & 32 & 51 & Martyrdom \\
\hline 14 & 33 & 52 & Mercy \\
\hline 15 & 34 & 53 & Missionary \\
\hline 16 & 35 & 54 & Pastoring \\
\hline 17 & 36 & 55 & Prophecy \\
\hline 18 & 37 & 56 & Teaching \\
\hline 19 & 38 & 57 & Wisdom \\
\hline
\end{tabular}




\section{APPENDIX F}

1. Some Characteristics of Unhealthy and Healthy Organizations. 
Evidence is mounting that conventional methods of management will no longer work: there is an awakening incerest in human-centered and participative approaches to the governing of institutions. If organizations are in trouble today, it is because tiney are failing to keen pace with the changing scene. A healthy organization las been definad as one that 'thas a strong sense of its own identity and mission, yet has the capacity to adapt readily to change." 6 inen efforts are nade today to identify the characteristics of healtiny as opposed to sick organizarions some of the attributes 1 isted below are sat down. They provide a seful backdrop against which to exanine clurch organizations in today's clianging world:

\section{SOME CIIARACTERISTICS OF \\ UNIEALTIY AVIE HEALTHY ORGANIZATICNS ${ }^{7}$}

\section{Unheàl thy}

There is little personal investment in organizational objectives except at top levels.

Feople in leadership positions try to control the decisions, often creating bottlenecks to action. Decisions are frequently made with inadequate information and advice. People complain about impractical or irrational decisions of leadership.

Subsystens of the organization work independently of one another and are frequently "in the dark" as to what is happening elsewhere.

The judgment and potential contributions of people "lower down" or on the periphery of the organization are not sought or respected.

The leader (manager) is thescribing father to the organization. irothing goes on or is decilied witlout his final approval. t!ealthy

Oujectives are widely shared by the members. There is a strong and consistent flow of energy toward those objectives.

The points of decision-making are proximate to t.:eir implementation and are determined by such factors as ability and availability of information.

There is an interdependency of the subsystems making maximum use of the human and other resources in various groups as the need requires.

The judment, gifts, skills and innut of people wherever located in the organization are sought and respected.

Laaderstip is flexible, shifting in style and person to suit the situatior.

Fordyce and lleil, p. 3 .

${ }^{7}$ Adapted in part from Fordyce and Weil, pp. 11-14. 
People feel deprived of choice and influence with respect to changes which affect them.

Leaders often "go it alone" in getting things done. Frequently projects, policies and procedures don't get carried out as interded.

Personal needs and feelings are side issues as compared to getting the job done for the organization.

There is competition between individuals and groups where collaboration is needed. People are jealous of their particular area of responsibility. There is little seeking or offering of help.

Conflict is mostly covert and handled politically in a win/lose atmosnhere. There are interminable and irreconcilable arguments.

People hide behind masks and formal ity. They often feel alone. There is an undercurrent of mistrust.

Organizational structure, policies, and procedures encumber the organization. People take refuge in policies and procedures and play games with organizational structure.

The behavior of people in staff, board, or committee neetings is listless and docile. They attend out of loyalty or duty but it's not much fun. They get their "kicks" elsewhere.

Feedback, self-assessment, evaluation are avoided.
Power and influence for change are widely shared by the individuals concerned.

There is a sense of team play in planning and perfomance. There is a sharing of responsibility.

Personal needs and human relationships are considered important in zchieving the goal of the organization.

Collaboration is freely entered into, People readily request the help of cthers and are viling to give in return. liays of helping one anothe are highly developed. Competition is healthy and in the direction of $a$ shared goal.

Conflict is considered valuable in decision-making and personal growth. It is dealt with effectively in the open. gscole Eael free to express their opinions and expect others to do the same.

Relationships aro open, ironest, iristing. Fcople cire about one anotilar and lend support to one another.

The organization's structure, procedures, and policies are means to ends, not to elevate the bureaucrat. They are also readily changed.

People are "turned on" and highly involved by choice. They find rewards and pleasure in working together ircluding in their group task sessions.

Joint critique of progress and group functioning is routine. 


\section{APPENDIX G}

1. A Roadmap of Iceland 


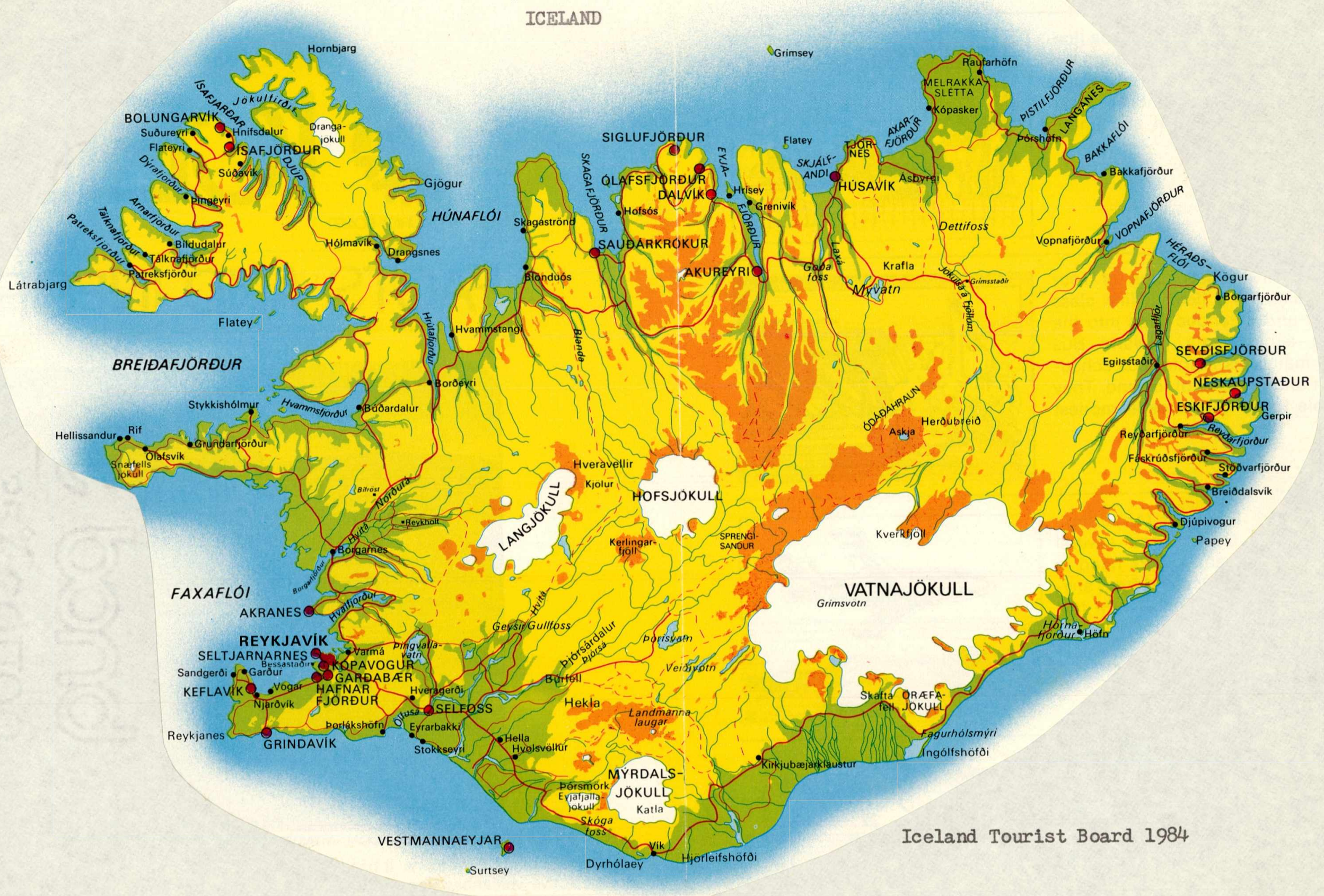


BIBLIOGRAPHY 
BIBLIOGRAPHY

Books

Blauw, Johannes. The Missionary Nature of the Church. Grand Rapids, Michigan: William B. Eerdmans Publishing Company, 1962 .

Boer, Harry R. "The Holy Spirit and Church Growth." In Exploring Church Growth, pp. 249-259. Edited by Wilbert R. Shenk. Grand Rapids, Michigan: William B. Eerdmans Publishing Company, 1983.

Chaney, Charles L., and Lewis, Ron S. Design for Church Growth. Nashville, Tennessee: Broadman Press, 1977.

Conn, Harvey M. "Looking for a Method: Background and Suggestions." In Exploring Church Growth, pp. 79-94. Edited by WilbertR. Shenk. Grand Rapids, Michigan: William B. Eerdmans Publishing Company, 1983.

Costas, Orlando E. "A Wholistic Concept of Church Growth." In Exploring Church Growth pp. 95-107. Edited by Wilbert R. Shenk. Grand Rapids, Michigan: William B. Eerdmans Publishing Company, 1983.

Davidsson, 0lafur. Galdur og Galdrama1 a Islandi. Reykjavik, Iceland: Solufelag, 1940-43.

Douglas, J. D., Ed. Let the Earth Hear His Voice. Minneapolis, Minnesota: World Wide Publications, 1975.

Dudley, Roger, and Cummings, Des, Jr. Adventures in Church Growth. Washington, D. C.: Review and Herald Publishing Association, 1983.

Genera1 Conference of Seventh-day Adventists. The Caring Church: A Strategy for North America. Washington, D.C.: the General Conference of Seventh-day Adventists. 1983.

Gjerset, Rnut. History of Iceland. New York: MacMillan Companj, 1924. 
Glasser, Arthur F. "Church Growth and Theology." In God, Man, and Church Growth, pp. 52-68. Edited by Alan R. Tippett. Grand Rapids, Michigan: William B. Eerdmans Publishing Company, 1975.

Glasser, Arthur F., and McGavran, Donald. Contemporary Theologies of Mission. Grand Rapids, Michigan: Baker Book House, 1983.

Greenleaf, Robert $\mathbb{R}$. Trustees as Servants. Cambridge, Massachussets: Center for Applied Studies, 1975.

Grimley, John B., and Robinson, Gordon E. Church Growth in Central and Southern Nigeria. Grand Rapids, Michigan: Eerdmans, 1966.

Haraldsson, Erlendur. "National Survey of Psychical Experiences and Attitudes Towards the Paranormal in Iceland. In Research in Parapsychology 1976. Edited by J. D. Morris, W. G. Roll, and R. I. Morris. Metuchen, New Jersey: Scarecrow Press, 1977.

Heimskringla. Everyman's Library, pp. 117-396. New York: E. P. Dutton and Company, n.d.

Hodges, Melvin L. "Creating Climate for Church Growth. In Church Growth and Christian Mission, pp. 27-39. Edited by Dona1d McGavran. New York: Harper and Row, 1965 .

Hogue, C. B. I Want My Church to Grow. Nashville, Tennessee: Broadman Press, 1977.

Hood, John C. F. Icelandic Church Saga. Westport, Connecticut: Greenwood Press, Publishers, 1981.

Hurn, Raymond W. "It's Back to Church Planting for the Nazarenes." Global Church Growth Bulletin 19, 1 $(1982): p \cdot 160$.

Hyde, Douglas. Dedication and Leadership. South Bend, Indiana: Notre Dame University, 1971.

"Iceland Conference." Seventh-day Adventist Encyclopedia. 1976 edition. 10:614.

Islendingasogur. Vo1. 1. Reykjavik, Iceland: Islendingasagnautgafan, 1946.

Islendingasogur. Vol. 3. Reykjavik, Iceland: Islendingasagnautgafan, 1946. 
Krass, Alfred. "Response to Orlando Costas' 'Postscript to the Theological and Methodological Thought of Donald McGavran." In Shattering Critique from the Third World. Wheaton, Illinois: Tyndale Publication, n.d.

McGavran, Donald. The Bridges of God. New York: Friendship Press, 1955.

- How Churches Grow. Glendale, California:

Regal Books, 1976.

- Understanding Church Growth. Grand Rapids, Michigan: William B. Eerdmans Publishing Company, 1970 .

- Understanding Church Growth. Grand Rapids, Michigan: William B. Eerdmans Publishing Company, 1980 .

Montgomery, James H. and McGavran, Donald. The Discipling of a Nation. Pasadena, California: Global Church Growth Bulletin, 1980.

Nordal, Johannes, and Kristinsson, Valdimar, eds. Iceland 874-1974. Reykjavik, Iceland: Central Bank of Iceland, 1975.

North American Division of Seventh-day Adventists. Faith Action Advance. Washington, D.C.: Review and Herald Publishing Association., 1979.

Oosterwal, Gottfried. "The Seventh-day Adventist Church in the World Today." In Servants for Christ, pp. 1-51. Edited by Robert E. Firth. Berrien Springs, Michigan: Andrews University Press, 1980.

Quilkin, J. R. Meaning of the Church Growth Movement. Chicago: Moody Press, 1974.

Schaller, Lyle E. Assimilating New Members. Nashville, Tennessee: Abingdon Press, 1978.

Schwarz, Richard W. Light Bearers to the Remnant. Mountain View, California: Pacific Press, 1979.

Shenk, Wilbert R., Ed. The Challenge of Church Growth. Elkhart, Indiana: Institute of Mennonite Studies, 1973 . 
Seamands, John T. "The Role of the Holy Spirit in Church Growth." In God, Man and Church Growth, pp. 95-107. Edited by Alan R. Tippett. Grand Rapids, Michigan: William B. Eerdmans Publishing Company, 1976.

Stephensen, Magnus. Island $i$ det 18de Aarhundrede. Copenhagen, Denmark: Den Gyldendahl Boghandlinger Forlag, 1803.

Tippett, Alan R. Church Growth and the Word of God. Grand Rapids, Michigan: William B. Eerdmans Publishing Company, 1970.

Walker, F. D. William Carey. Chicago: Moody Press, 1925 .

White, Ellen G. Acts of the Apostles. Mountain View, California: Pacific Press Publishing Association, 1911 .

- Christian Service. Washington, D. C.:

General Conference of Seventh-day Adventists, 1947.

- Evangelism. Washington, D. C.: Review and Herald Publishing Association, 1946.

- Testimonies for the Church. Vo1. 3. Mountain View, California: Pacific Press Publishing Association, 1948.

Winter, Ralph D. Crucial Issues in Missions Tomorrow. Edited by Donald McGavran. Chicago: Moody Press, 1972 .

- Penetrating the Last Frontier. South Pasadena, California: William Carey Library, 1979.

Periodicals--Journals

Lin, David. "Years of Heartbreaks: Lessons for Missions by a China Insider." Spectrum 7, 3(1975):25.

McGavran, Donald. "Essential Evangelism: An Open Letter to Dr. J. C. Hoekendijke." W. C.C. Occasional Papers, Series 3 , no. 2 .

Padilla, Rene C. "A Steep C1imb Ahead for Theology in in Latin America." Evangelical Missions Quarterly, Winter 1971, pp. 104-105. 
Swatos, William H. Jr., "The Relevance of Religion: Iceland and Secularization Theory." Journal for the Scientific Study of Religion 23 (March 1984): 32-38.

Periodical--Magazines

Bradford, Charles. "The Need of Goals." Adventist Review, November 8, 1984.

Durand, Eugene F. "The Year 1984 in Review." Adventist Review, December 27,1984, p. 7 .

"Editorial." Thjodolfur, January 22, 1898, p. 20.

Iceland Conference of Seventh-day. Adventists. Braedrabandid (1935-1983).

Knight, George R. "Spiritual Revival and Educational Expansion." Adventist Review, March 29, 1984.

"A Church Growth View of Adventists." Northern Light, 34 (May 1984):3.

Raft, J. C. "Iceland." General Conference Bulletin, May, 1909 , p. 127.

White, Ellen G., "Trust in the Lord." Review and Herald, February 3,1885 .

Miscellaneous

Faculty of Hlidardalsskoli. Letter to the School Board of H1idardalsskoli, February 5, 1982.

General Conference of Seventh-day Adventists Statistical Report (1950-1983). Washington, D.C., Genera1. Conference of Seventh-day Adventists.

Government of Iceland. Hagtidindi. Reykjavik, Iceland: Bureau of Statistics, (1860-1983).

Gudmundsson, Julius., to Steinthor Thordarson, Ju1g 1973.

Hallgrimsson, Sigfus. Reykjavik, Iceland. Interview, March 1973.

Iceland Conference of Seventh-day Adventists (Reykjavik, Iceland). Financial Statement for Hlidardalsskoli 1981 and 1982 . 
Iceland Conference of Seventh-day Adventists (Reykjavik, Iceland). Minutes of Meetings of the Conference Executive Commitee, 1940 to 1980.

Iceland Conference of Seventh-day Adventists (Reykjavik, Iceland). Minutes of a joint meeting of the

Conference Executive Committee and the School Board of H1idardalsskoli, April 8, 1976.

Kristjansson, Gudni. "Early History and Development of the Seventh-day Adventist Church in Iceland." M. A. thesis, Andrews University, 1977. Missionary Life." A term paper, Andrews University, 1977.

Oosterwa1, Gottfried. "Introduction." A Course Description for a Seminar in Church Growth. Andrews University, Berrien Springs, Michigan, February, 1984 .

MSSN 600 Seminar in Church Growth. Class notes, Andrews University, Berrien Springs, Michigan, February, 1984.

Snorrason, Bjorgvin. "Pastor David Ostlund and the Beginnings of the Seventh-day Adventist Church in Iceland." M. A. thesis, Andrews University, 1975.

Thordarson, Steinthor. "The Seventh-day Adventist Church in Iceland Since 1928." M.A. thesis, Andrews University, 1973.

White, Ellen G. Letter 106, May 20, 1903. Ellen G. White Research Center. Andrews University, Berrien Springs, Michigan.

- Letter 94a, June 6, 1909. Ellen G. White Research Center. Andrews University, Berrien Springs, Michigan 
VITA

Steinthor Thordarson was born into a Lutheran family at Sandur, Iceland, on August 29, 1937. Upon completing elementary school he attended the SDA secondary school, Hlidardalsskoli, in Iceland from 1952 to 1955. While at Hlidardalsskoli he was baptized into the Seventh-day Adventist Church (in 1954).

Degrees Awarded:

Bachelor of Arts in religion, Andrews University, 1964

Master of Arts in religion, Andrews University, 1973

Master of Divinity equivalence, Andrews University, 1983

Doctor of Ministry, Andrews University, 1985

Professiona1 Experience:

1964 - 1966 Pastor, Vestmannaeyjar, Iceland

1966 - 1970 Evangelist, Akureyri, Iceland

1970 - 1976 Pastor, Keflavik, and conference departmental

director, Iceland

1976 - 1977 Pastor and Bible teacher, Hlidardalsskoli, Iceland

1978 - 1981 Mission president, Rivers State, Nigeria 